\title{
HYDRAULIC ANALYSIS AND SIMULATION OF THE INKAMISNA AT OLLANTAYTAMBO, PERU
}

\begin{tabular}{c} 
A Thesis \\
Presented to \\
the faculty of the School of Engineering and Applied Science \\
University of Virginia \\
\hline in partial fulfillment \\
of the requirements for the degree \\
Master of Science (Civil Engineering)
\end{tabular}

by

Benjamin M. Doran

December 2012 


\author{
APPROVAL SHEET \\ This thesis is submitted in partial fulfillment of the \\ requirements for the degree of \\ Master of Science (Civil Engineering)
}

Benjamin M. Doran

Author

This thesis has been read and approved by the examining committee:

Dr. Richard W. Miksad

Advisor

Dr. Joanna C. Curran

Dr. Thomas T. Baber

Kenneth Wright, P.E.

Emily C. Becker, P.E.

Eliot Wong, E.I.T., CFM

Accepted for the School of Engineering and Applied Science:

Dr. James Aylor

Dean, School of Engineering and Applied Science

December 2012 


\section{Table of Contents}

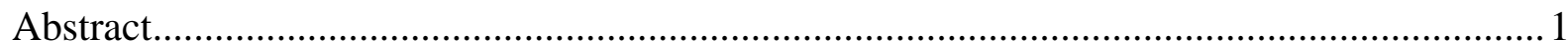

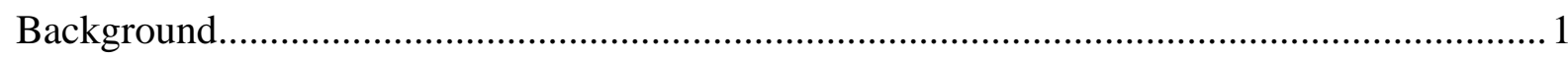

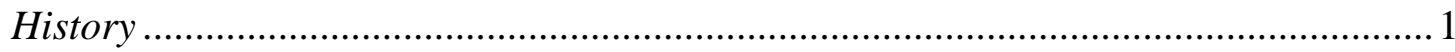

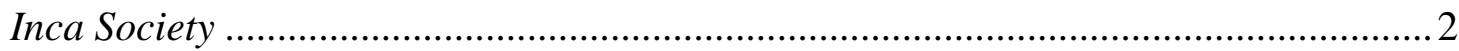

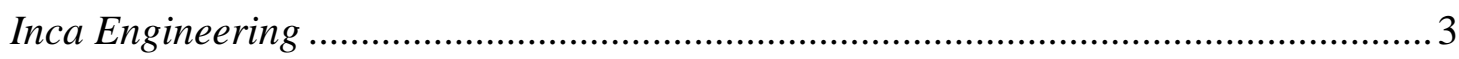

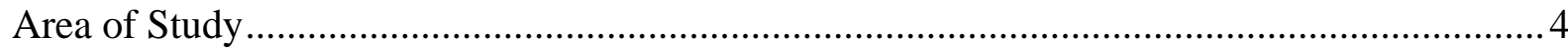

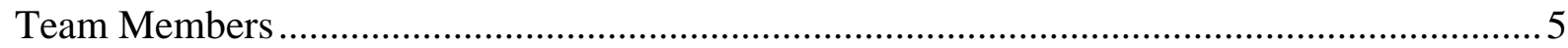

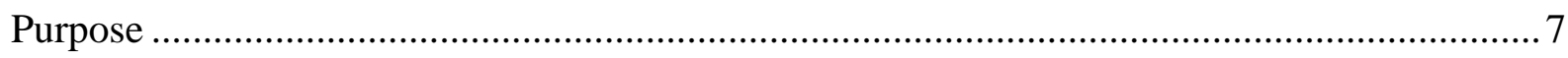

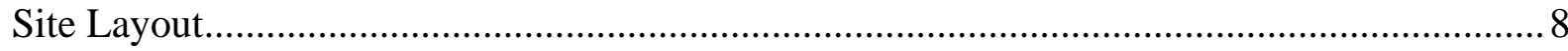

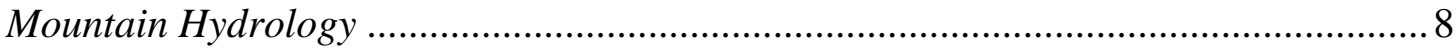

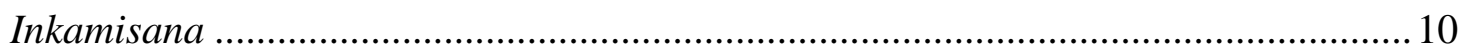

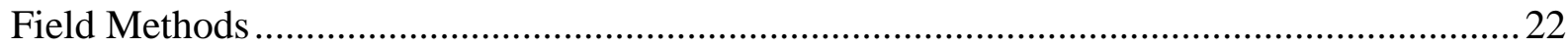

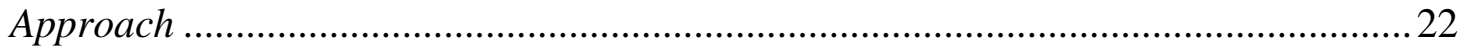

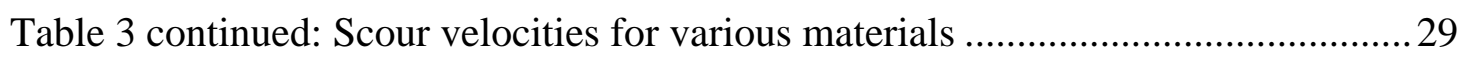

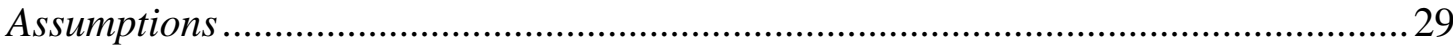

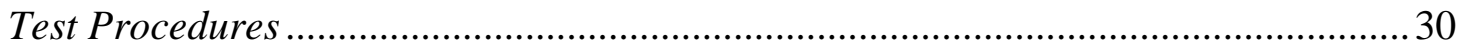

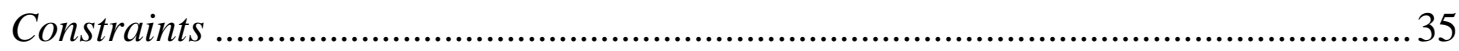

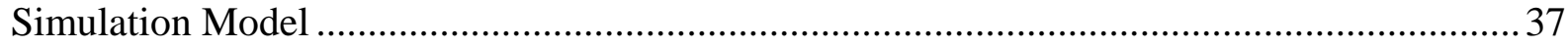

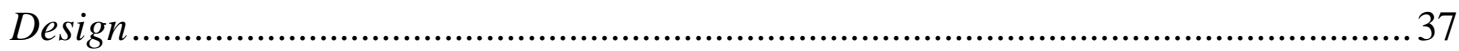

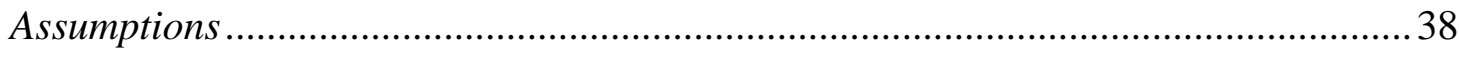

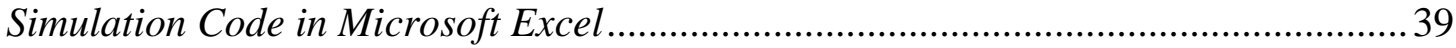

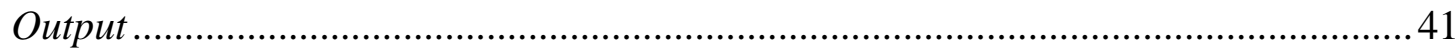

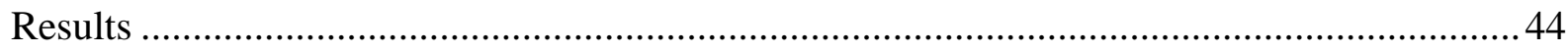

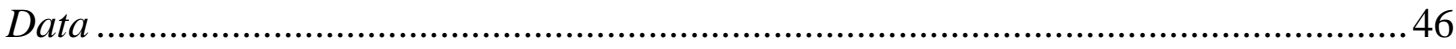

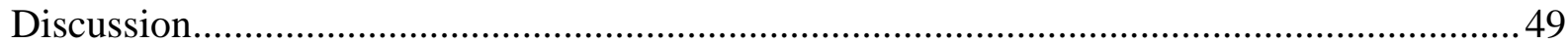

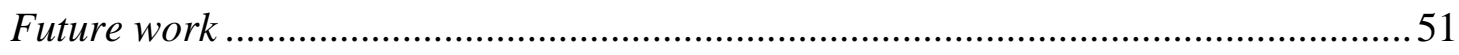

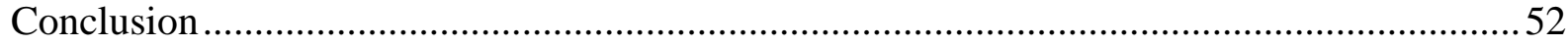

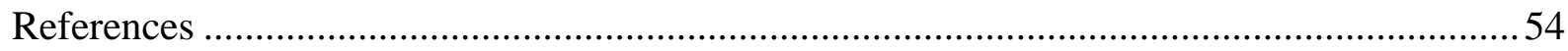

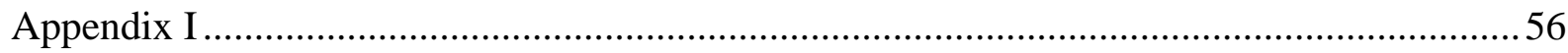




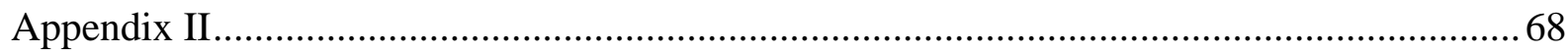

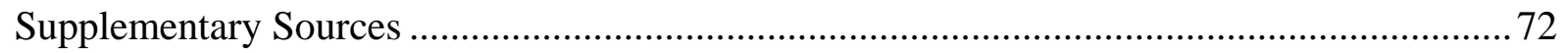

\section{List of Figures}

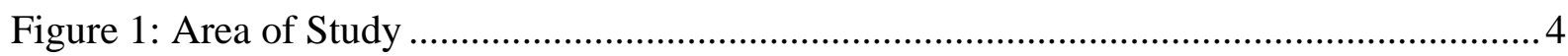

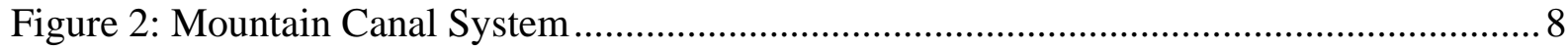

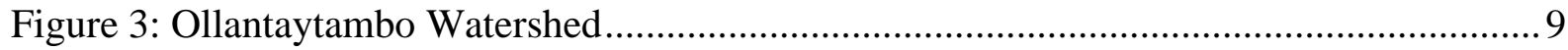

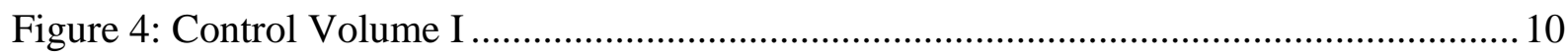

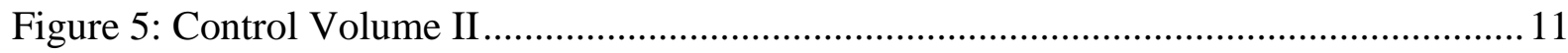

Figure 6: Bifurcation of Inkamisana Complex feed channel................................................... 11

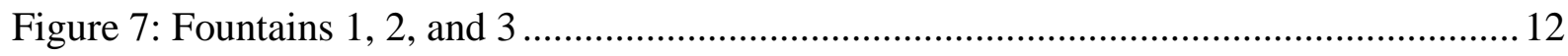

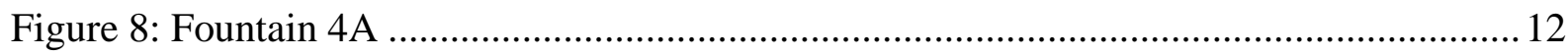

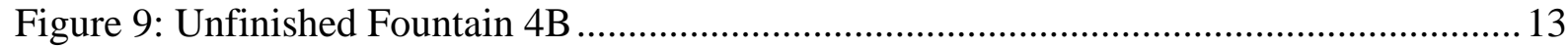

Figure 10: Unfinished Fountain 4C ................................................................................ 13

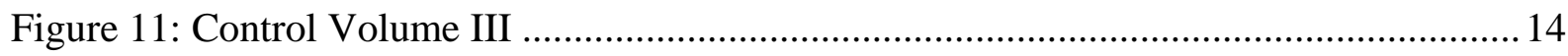

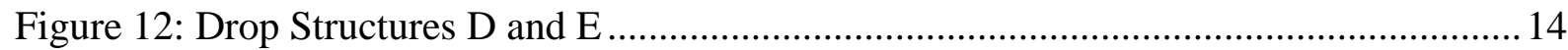

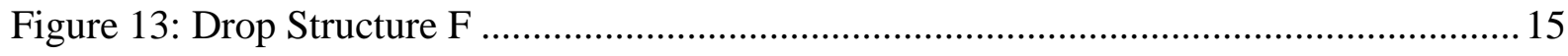

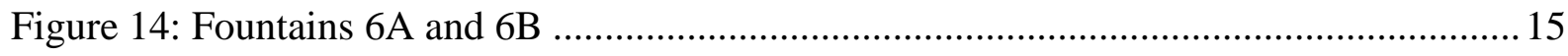

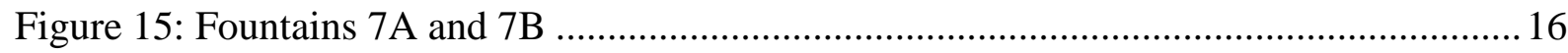

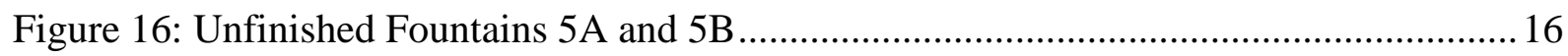

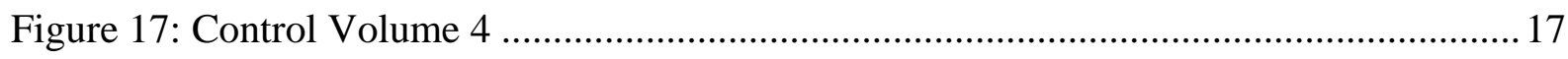

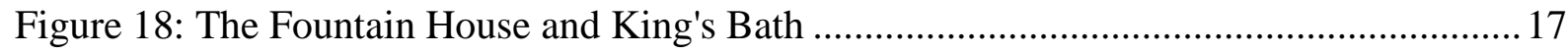

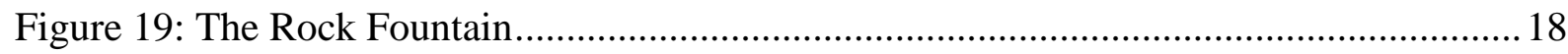

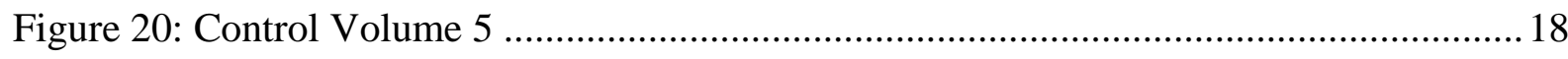

Figure 21: The Upper Fountain .................................................................................... 19

Figure 22: The Princess Fountain ..................................................................................... 19

Figure 23: Aerial view of Fountain House Complex …………………………………....2 20

Figure 24: Channel Locations in control volumes 1-2 ........................................................ 21

Figure 25: Channel locations in control volumes 2-5 ..........................................................2 21 


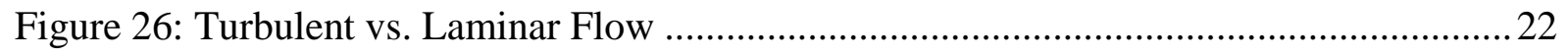

Figure 27: Particle Reynolds number vs. Shields parameter (Guo, 2002) ............................ 24

Figure 28: Derivation of Manning's Equation (Crowe, 2009) ............................................26

Figure 29: Derivation of Manning's Equation continued (Crowe, 2009) ..............................2 27

Figure 30: Flow depth vs. specific energy for varied flows (Mays, 2005) .......................... 28

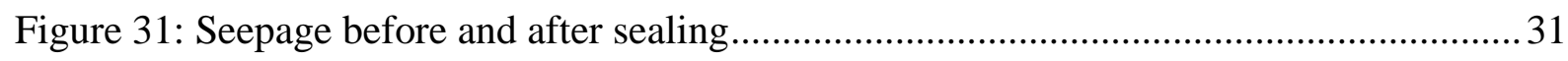

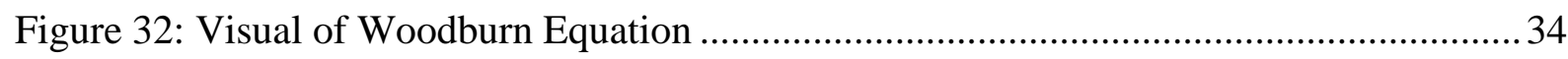

Figure 33: Derivation of Woodburn Equation (Crowe, 2009) ........................................... 35

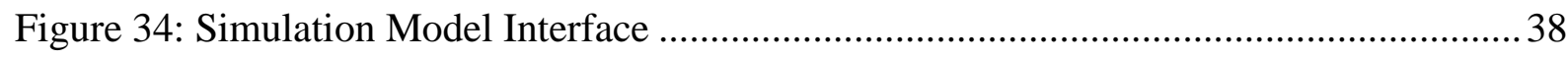

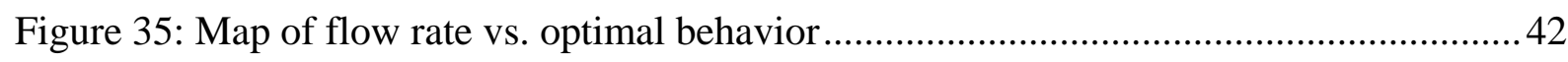

Figure 36: Map of flow rates vs. flow characterization................................................ 43

Figure 37: Map of channel velocity vs. self-cleaning capability ......................................... 44

\section{List of Tables}

Table 1: Viscosity of Water vs. Temperature.................................................................2 23

Table 2: Manning's Coefficient, $\mathrm{n}$, for various materials .................................................. 25

Table 3: Scour velocities for various materials .......................................................... 28

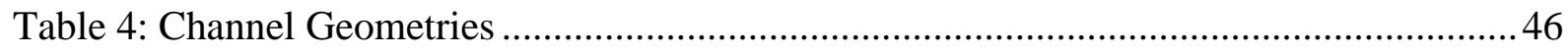

Table 5: Channel capacity and corresponding Froude value......................................... 47

Table 6: Fountain Optimum Flow Requirements as per each method (gpm) ....................... 48

Table 7: Minimum Self-Cleaning Velocities ............................................................ 48

Table 8: Sediment Transport Parameters ....................................................................... 49 


\begin{abstract}
Over the course of two summers, a team of engineers and archaeologists from the University of Virginia, Wright Paleohydrological Institute and the National Institute of Culture in Peru studied Inca ruins at Ollantaytambo, Peru. The site, known as the Inkamisana, was used by the Inca for the worship of water and incorporates a flow network system for distributing water to sixteen different fountains. Water from the surrounding Patacancha watershed supplied water to the Inkamisana via a series of canals that run along the mountainside.
\end{abstract}

This report discusses the portion of the research that dealt with the hydraulic study of the fountains, drops, and channel structures that are part of the Inkamisana. There were three primary goals of this study:

1) Verify and update current plans of the site

2) Hydraulic analysis of the flow network

3) Simulation model of the flow network

The verification process included comparing the location and dimension of all fountains, channels, and drop structures to what were shown on previous plans. Correct flow paths of water throughout the site, especially at points of underground flow had to be documented. The hydraulic study consisted of an optimal flow analysis of flow behavior with respect to water supply. Flow parameters studied included 'self-cleaning' capability (sediment transport), scouring, jet behavior, and flow characterization (e.g. turbulent vs. laminar, supervs. sub-critical). The simulation model incorporates varied inputs (e.g. source flow rate, valve behavior) to model behavior of the site under desired scenarios. The model also produces descriptive maps that relate these properties to their corresponding hydraulic elements.

This research project was the first hydraulic analysis completed of the Inkamisana. Ultimately it gives a comprehensive understanding of the hydraulics that govern one of the most magnificent fountain complexes in Peru. Knowledge and methods developed from this research can also be applied in the analysis of future studies of Inca ruins.

\title{
Background \\ History
}

For centuries, people groups attained control over regions in Peru. Based upon the size of the kingdom and the number of people within it, a polity was able to survive. Over time, the Inca kingdom came into existence in the southern region of Peru. In its early stages, the kingdom was small and insignificant. Thus, when its king Viracocha Inca fled his throne in fear of another larger kingdom, the Inca were on the verge of being expunged before they could ever become a dominant empire. It was at this point that the first Inca emperor, Cusi Yupanqui, came to rise (MacQuarrie, 2007). The son of Vircacocha, he seized the opportunity left be the voided throne to lead the Inca to a series of military conquests throughout Peru. Thus began the great Inca Empire that would last for over a century. 
From its rise to dominance, to the eventual collapse at the hands of the Spanish, the Inca were ruled by 11 different emperors. Cusi Yupanqui was the first of these emperors. Upon seizing the throne he changed his named to Pachacuti (which means "he who turns the world upside down") and proceeded to restructure the Inca Kingdom of his father. He conquered or assimilated most of their neighboring tribes, creating for the first time an Inca empire. "Pachacuti called his new empire Tawantinsuyu or "the four parts united" (MacQuarrie, 2007).

When the Spanish conquistador Francisco Pizarro arrived for the second time in Peru, the demise of the Inca Empire had already begun. After Emperor Huayna Capac died from European-introduced small pox a few years earlier, Atahualpa became the next in line emperor. When he was captured by the Spanish in 1531, the swift and brutal conquest of Peru began. Although he cooperated by bringing Pizarro much of the gold in his kingdom, Atahualpa was put to death in 1532. This was the first of many executions to come.

As the Spanish went throughout Peru conquering the Inca, they established puppet emperors and killed all who opposed them. One Inca Emperor, Manco Inca, fiercely fought against the Spanish. Initially a puppet emperor to the Spanish, Manco revolted when his wife was stolen and then executed by Pizarro. He then led vicious attacks against the Spanish for many years until he was forced to retreat into the Amazon. Manco was later murdered in 1544.

Several more Inca Emperors came to rise and sequentially died at the hands of the Spanish. When the final Inca emperor, Tupac Amaru, was captured and then executed in 1572, the long line of Inca Emperors was finally ended (MacQuarrie, 2007). After over 100 years of power, the Inca Empire would cease to exist.

\section{Inca Society}

The Inca civilization was one of the largest and most advanced people groups to exist. Their empire began during the 1400's through conquest and assimilation of neighboring tribes along the west coast of South America. However, the ability to maintain their empire was due in large part to their ability to create an effective social structure. This social structure was comprised of a broad spectrum of societal groups, where each group had a unique role to fulfill in order for society to effectively function. The Sapa Inca, or unique emperor, was the absolute top of the social pyramid and was seen as a God-like presence. Nobles were either priests or relatives of a past or current Sapa Inca and were next highest on the social latter (D'Altroy, 2002). After the nobles were working class citizens. Farmers were lower on this spectrum than those with specialized skills, such as architects and craftsmen. Peasants and captured peoples were the lowest class and were used primarily for manual labor.

The Inca also had innovative concepts for the design and management of their empire. The empire was divided into regions and then into provinces where imperial governors were left as heads of the local Inca administration. These governing bodies had the power to tax local peasants in order to sustain the rest of the empire. A roadway system was also constructed to link major cities and important structures such as forts, storehouses, and temples. Inca cities had a specific layout too: Noble descent groups lived close to the city center while peasants lived in the surrounding hillside. This provided safety from attacks as well as proximity to 
official and ceremonial buildings. Although the Inca did not have a known writing system, their language and record keeping were still advanced. The Inca language was called runasimi, or 'people speech', and included specific words for people with unique tasks or purposes (D'Altroy, 2002). A system of colorful knot tying called quipus was used to store numerical data and as a memory prompt for recounting oral histories.

\section{Inca Engineering}

The Inca were known for their engineering practices, specifically in regards to water engineering. Design of water systems was influenced by the fact that they viewed water as both a physical and spiritual phenomenon. "The Inca civilization considered itself as arising from water..." (Mazadiego, 2009). When designing these systems, the Inca would run the water first to the residence of the most important official living there. By doing this, the official would have access to fresh water before it would be used by others. The Inca had advanced understanding of modern hydraulic principles. They were able to design channels to avoid hydraulic jumps (or implement them when necessary) as well as supply sufficient water to fountains. This was especially tough since flow rates relied upon seasonal rainfall amounts.

The Inca were also able to develop successful construction methods. For instance, impermeable rock was used a liner to prevent water from seeping out of canals. To protect against landslides and erosion of foundations multi-leveled terraces were connected to drainage canals. In order to transport large stones used for construction, the Inca developed a slide system of levers and round poles. Once in place, t-shaped groves and an h-shaped copper clamp attached many of these massive stones. The Inca were also able to use mathematics to aid construction. A measuring system based upon units of 10, which included decimals, allowed for reliability and consistency in design (Wright et al, 2000). Scaled models were frequently used as visual aids when designing and constructing large sites.

Inca engineers also had to optimize the tools and resources they had available. Bronze was used to make tools such as knives, crowbars and axe blades while stones were used as hammers and silver for plumb bobs. Stone was the main building material and was quarried from nearby locations. Wood from nearby forests was used primarily for roof structures, doorways, stairways, second floors, and lofts. Much of the labor for projects came from slaves or peasants who owed a labor tax every year.

At the height of its civilization, the Inca Empire extended along much of the western coast of South America. Throughout their empire, the Inca constructed and/or incorporated preexisting sites to us as capitals, places of worship, and for military purposes. One such place is Ollantaytambo, located 60 kilometers northwest of Cusco at the junction of the Urubamba and Patacancha Rivers. In the mid $15^{\text {th }}$ century the Inca emperor Pachacuti conquered the region and assimilated its people and the land as part of his empire (D'Altroy, 2002). During the next century Ollantaytambo was used as both an estate and place for worshiping water, a sacred element for the Inca. A century later in 1536 the emperor Manco Inca retreated to Ollantaytambo during the Spanish conquest of Peru. During that time the site served as a fortress and additional construction of fountain complexes began. After using Ollantaytambo 
as a temporary capital for a year Manco Inca retreated further into the Vilcabamba Valley. This forced retreat resulted in portions of the construction to be left uncompleted.

\section{Area of Study}

The study was completed by a team of engineers from the University of Virginia and WPI spent two summers studying the watershed hydrology of Ollantaytambo and the hydraulics of the fountain complexes down valley (see Figure 1).

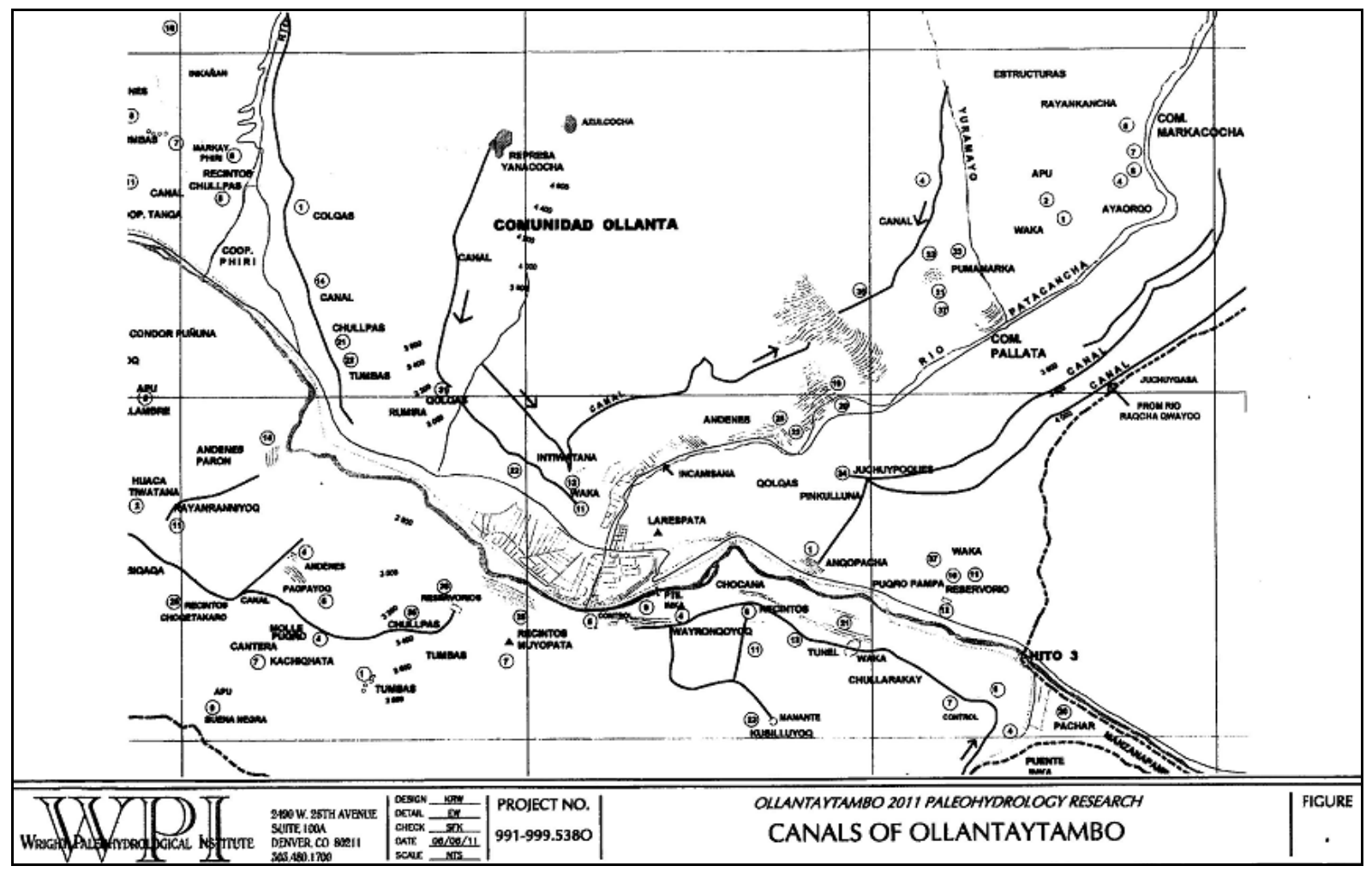

Figure 1: Area of Study

The watershed study consisted of an in depth analysis of rainwater runoff and collection, land cover, and transportation of water from Media Luna to supply the Inkamisana. The hydraulic study of the fountain complexes began at the diversion of water upstream of the eight terrace complex and included the Inkamisana, Fountain House Complex, and the Princess Fountain Complex.

Ollantaytambo is located in a water rich region with both the Patacancha and Urubamba rivers as reliable water sources for the fountain and terrace complexes constructed by the Incas. It is located at nearly a 3,000 meter elevation and approximately 70 kilometers northwest of Cusco. There are numerous unfinished blocks across the valley that had been intended for the site. The unfinished work was due to a revolt by the masonry workers (the workers were sons of Chuchi Capac, chief of the Colla tribe, who had been defeated by Pachacuti and were forced into slave labor). From 1536-1537 the area served as Manco Inca's headquarters until further Spanish pursuit forced the Inca further into the jungles. In the 400 years following Inca inhabitance, the Patacancha valley experienced large landslides and a flood that 
deposited over 8 feet of sediment on the valley near the King's Bathhouse. From 1980 to 1982 Peruvian archaeologist Dr. Arminda Gibaja Oviedo began excavating the Inca ruins at Ollantaytambo.

Known today as some of the finest water engineers, the Inca developed methods for hydrology and construction unique to their environment. Their intuitive understanding of hydraulic engineering allowed them to create magnificent displays of flowing water at sites throughout Peru. One site in particular, Ollantaytambo, is at the base of the Patacancha Valley. There, the Inca built what is now known as the Inkamisana, a masterpiece in water temple designs. The Inkamisana is comprised of multiple fountain networks used for the religious worship of water. To feed these fountains, the Inca utilized existing canals to design an extensive system for transporting water from up the valley. A common myth is that a mystical spring is the sole source of water for these canals. However, the canals actually collect water from the surrounding watersheds before transporting it, sometimes upwards of 50 kilometers. Although not much is known about the engineering of this site, other Inca ruins at Machu Picchu, Moray, and Tipon give insight into the Inca approach to water engineering.

Inca ruins at Ollantaytambo can be divided into three main sections: the Inkamisana, Fountain House, and Princess Fountain Complexes. Altogether there are sixteen fountains; twelve of which are operable and four more that were under construction when the site was abandoned in the mid $16^{\text {th }}$ century. A couple of the fountains have ornate designs, symbolizing the religious significance of the site. All channels and fountains in these networks operate by gravity flow and rely on two different water supplies. Also located in the Inkamisana complex is a sacred rock and several niches that would have been used for holding the remains of Inca ancestors. In addition, there are dozens of mysterious rock carvings on the cliff face adjacent to the first four fountains.

The Patacancha valley is further divided into four main watersheds, the Yuracmayo, San Pablo, Paq'chapata, and Puma Paqcha (or Media Luna). Across these four basins, the Inca redesigned a canal system that runs for several kilometers. Many of the canals in the system were originally built by the Killke, a culture that inhabited the region prior to the Inca. These canals were primarily used as irrigation for the hundreds of terraces that can be found along the valley. The Bandolista canal, however, is a potential source of water for the Inkamisana. It is fed by the Puma Paqcha watershed and not by a spring. Numerous sections of the canal though have been destroyed by landslides making it difficult to track across its entire extent.

\section{Team Members}

This project was a cooperative effort between engineers and archaeologists from the U.S. and Peru. Team members include:

Dr. Arminda Gibaja Oviedo, Chief Archaeologist

Ives Bejar Mendoza, Archaeologist

Hugo Hannco, Archaeologist 
Fredy Copa, Archaeologist

Kenneth R. Wright, Director and Paleohydrologist

Ruth M. Wright, Photographer and Historian

Gordan F. McEwan, Scientific Advisor

Dr. Richard W. Miksad, Hydraulic Engineer

Fermin Gilberto Diaz, Advisor

Emily C. Becker, Hydraulic Engineer

Eliot J. Wong, Hydraulic Engineer

Sally F. Kribs, Technical Engineer

Luke Wildfire, Mountain Hydrologist

Mason Lacy, Fountain Hydraulics

Carlos Arriola, INC Site Manager

Ivan Montesinos, INC Site Guide

Emilio Alvarez, INC Assistant

Americo Guillen, INC Assistant

Kurt A. Loptien, Cartographer

Jenna Sollner, Mountain Hydrologist

Dr. Joanna Curran, Hydrology Engineer

Dr. Alexi Vranich, Archaeologist

Spencer Lacy, Mountain Hydrologist

Ken Lohr, Fountain Hydraulics

Tosh Bance, Mountain Hydrologist

Tom Baber, Research Advisor

WPI, a non-profit foundation based in Denver Colorado, has been involved with studying Inca sites for the past 15 years. WPI is one of the forefront experts in Inca hydraulics and hydrology. Ken Wright, the founder of the firm, has been working with the Instituto Nationale de Cultura (INC) for years and is the author of several books on Inca engineering. His wife, Ruth, has accompanied him to each site and has written several of her own books on Inca sites. Emily Becker and Eliot Wong, both professional engineers at W.W.E. who specialize in hydraulics and stormwater management, were also part of the research team. One of the project's advisors, Richard Miksad, teaches several water engineering courses at the University of Virginia including several paleohydrologic courses. He has been working with W.W.E. the past ten years.

Another member of the team is Luke Wildfire, a recent graduate of UVa and newly hired engineer at W.W.E. He joined Wright, Becker, Wong, and Miksad in the summer of 2011 to complete the initial surveying of the site. Fellow graduate student Jenna Sollner has been studying the watershed of the surrounding valley. Her work in understand the water sources in the area is a vital element of this research. Another professor at the University of Virginia, Dr. Joanna Curran, also serves as an advisor for this project. Her background is in fluvial geomorphology and water resources.

Dr. Oviedo and Fermin Diaz are two contacts with the INC in Cusco. They were able to procure a permit for W.P.I. to work at the site the past two summers. Carlos Arriola, Ivan 
Montesinos, Emilio Alvarez, and Americo Guillen are site managers for the INC and facilitated access to the site during field work. They have been studying the site since its first excavation. Dr. Oviedo was the head archaeologist during the initial excavation and is the foremost expert of the ruins at Ollantaytambo. Mendoza, Hannco, and Copa assisted Dr. Oviedo in field archaeology. Dr. Alexi Vranich is a Research Professor at the Cotsen Institute of Archaeology at UCLA. He has been working as an archaeologist in South America since 1995 and has been a valuable resource for understanding Inca society.

Several engineering students at UVa and Colorado University were part of the team that conducted field tests at Ollantaytambo in August, 2012. Ken Lohr, Tosh Bance, and Spencer Lacy were valuable assistants to the research team. Other workers at the site and local Peruvians were also integral parts of gathering information about hidden or unknown ruins vital to the research project.

\section{Purpose}

This portion of the research at Ollantaytambo was the hydraulic study of the Inkamisana (both the Upper and Lower Misana), Manyaraki, and Princess Fountain complexes. Dr. Miksad and Mr. Wright were the supervising engineers on site. There were three primary goals of this research project:

1) Verify and update current plans of the site

2) An in-depth hydraulic analysis of the flow network

3) Create a simulation to model site

The verification process included comparing the location and dimension of all fountains, channels, and drop structures to what was shown on the site plans. The research team also had to map the correct flow path of water throughout the site, especially at points of underground flow. This was an essential process in order for us to accurately analyze the flow behavior. The hydraulic study consisted of an optimal flow analysis and modeling of flow behavior with respect to water supply.

The primary outcome of this research is to complete the first hydraulic engineering analysis of the Inkamisana. One aspect of the study was to calculate the flow required for each fountain and for the entire complex to operate ideally. Another aspect was to evaluate whether current sources to the site were adequate or if additional water was required. The project team was also interested in comparing the behavior of each channel in regards to critical flow, selfcleaning velocity, and potential scouring. Ultimately, the team wanted to know if the network was capable of distributing the required flows while balancing the behavior of each channel and fountain. The end result is a comprehensive understanding of the hydraulics that govern one of the most magnificent fountain complexes in Peru. This information will be a valuable tool for helping the Peruvians better understand their ancestor's culture and pursue the future analysis of other Inca ruins in Peru. 


\section{Site Layout}

\section{Mountain Hydrology}

The source of water to the Inkamisana Complex can be traced from several kilometers up valley. An in depth study of the mountain hydrology helped to distinguish between the various watersheds for stormwater runoff as well as rivers, streams, and channels that help transport this water (see Figure 2 and Figure 3).

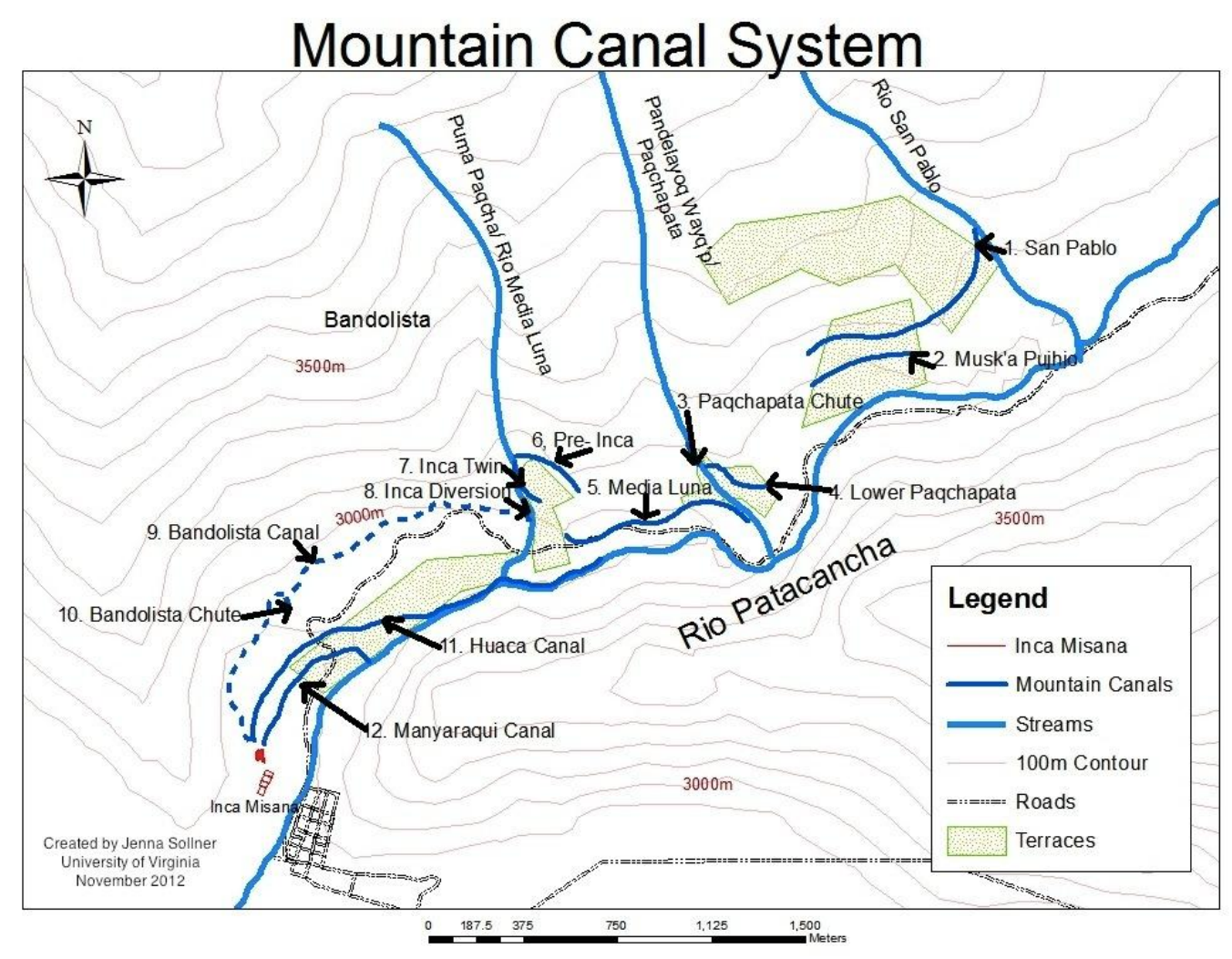

Figure 2: Mountain Canal System

The four sub-basins that were studied are named (up-valley to down-valley) Qbra Yuracmayo, Qbra San Pablo, Qbra Paq'chapata, and Qbra Puma Paqcha or Media Luna (Qbra is the abbreviation for Quebrada which is Spanish for gully or ravine). 


\section{Ollantaytambo Watershed}

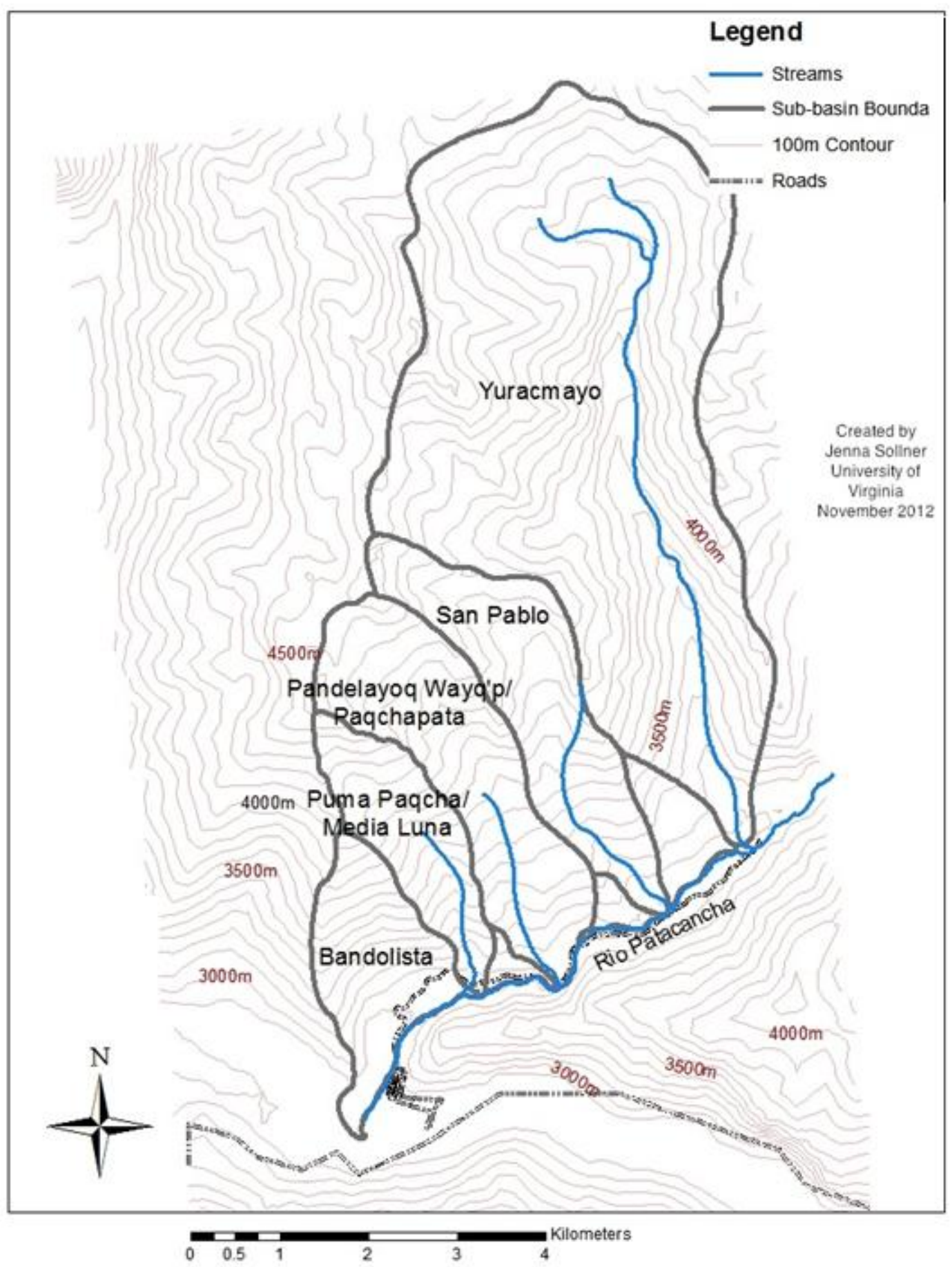

Figure 3: Ollantaytambo Watershed 
These basins have three rivers, the Rio Machamayo, Rio Paq'chapata, and Rio Media Luna that collect runoff and then flow into the larger Rio Patacancha. The Rio Paq'chapata ends with a length of steep canal called the Paq'chapata Chute. There are two known canals originating in the Qbra Yuracmayo, near the archaeological ruins of Puma Marca. A high canal crosses the valley and briefly continues above a set of giant terraces until there is no evidence of it any continuing further. A low canal crosses the valley and continues across the same set of terraces. This canal originates above the town of Bandolista and for convenience the research team refers to it as the "Bandolista Canal". Many localized irrigation canals are located in Qbra Paq'chapata. One canal extends down the Rio Patacancha valley to the Media Luna terraces where it ends. There is no evidence of any other canals extending further downstream.

In Qbra Puma Paqcha a low canal supplied by the Paq'chapata extends down the Rio Patacancha towards the village of Bandolista. Much of the remnants of this canal were destroyed in a landslide. Down-valley there is evidence of the canal extending to the Inkamisana. The pieces that remain indicate it was pre-Inca (Killke) and signify that it most likely would have continued to the 8 terrace complex prior to the Inkamisana. The Qbra Puma Paqcha is the only mountainside source for the Bandolista Canal which is the first source of water for the Inkamisana. Figure 2 shows the location of the Inkamisana relative to the surrounding rivers and canals in the valley. The Huaca and Manyaraki canals both branch from the Rio Patacancha up valley. Prior to the Inkamisana bifurcation, the Huaca canal ends up joining the Bandolista Canal to create the first source. The Manyaraki canal is the second source to the Inkamisana Complex.

\section{Inkamisana}

The site can be broken into five distinct control volumes which helps with analyzing water flow throughout. The first control volume is located at the far north end of the study area.

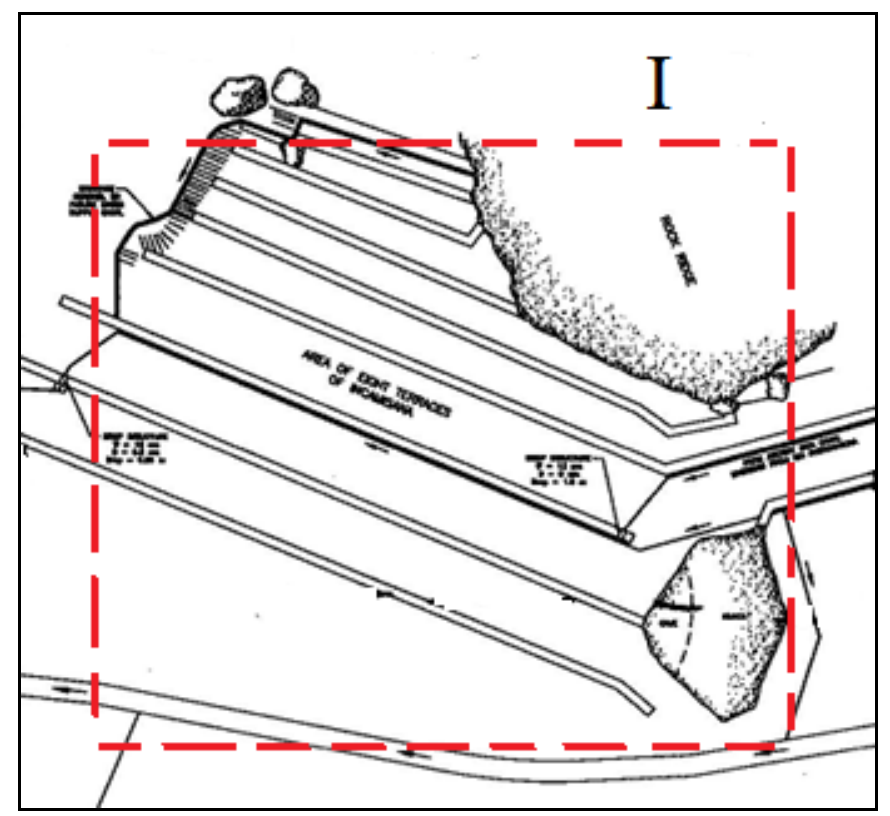

Figure 4: Control Volume I
It includes a set of eight terraces, a retention basin, a Huaca, and several channels that bring water from up the valley. The Bandolista Canal and Huaca Canal are the primary channels that were studied in this control volume. Both are sources to the subsequent fountain complexes located down valley. Prior to reaching the Huaca rock, the Huaca Canal splits into two smaller channels; one feeds the Misana Complex and the other feeds the Manyaraki Canal. The Bandolista Canal runs along the left side of the eight terraces and then combines with the Huaca Canal at the base of Terrace 1. This channel then feeds into control volume II, or the Upper Misana. 


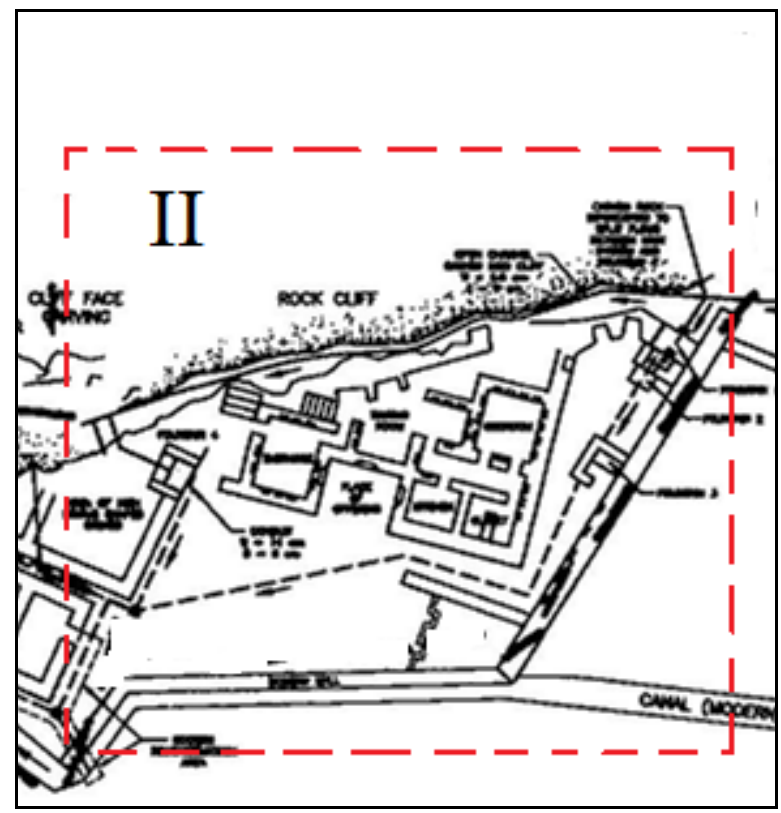

Control Volume II includes

Fountains 1, 2, 3, and 4A and the unfinished Fountains $4 \mathrm{~B}$ and $4 \mathrm{C}$. It begins at the bifurcation point and ends where outflow from Fountains 4A and 3 join. Flow that enters control volume II via the bifurcation is one of the two sources for the site. This channel is essential to the overall behavior to the Inkamisana.

Figure 5: Control Volume II

There is an immediate bifurcation (splitting) of the feed channel to the Inkamisana.

Figure 6 below shows this bifurcation. One of these channels feeds Fountains 1, 2, and 3 . These channels are in series and form a cascading flow pattern as shown in Figure 7.

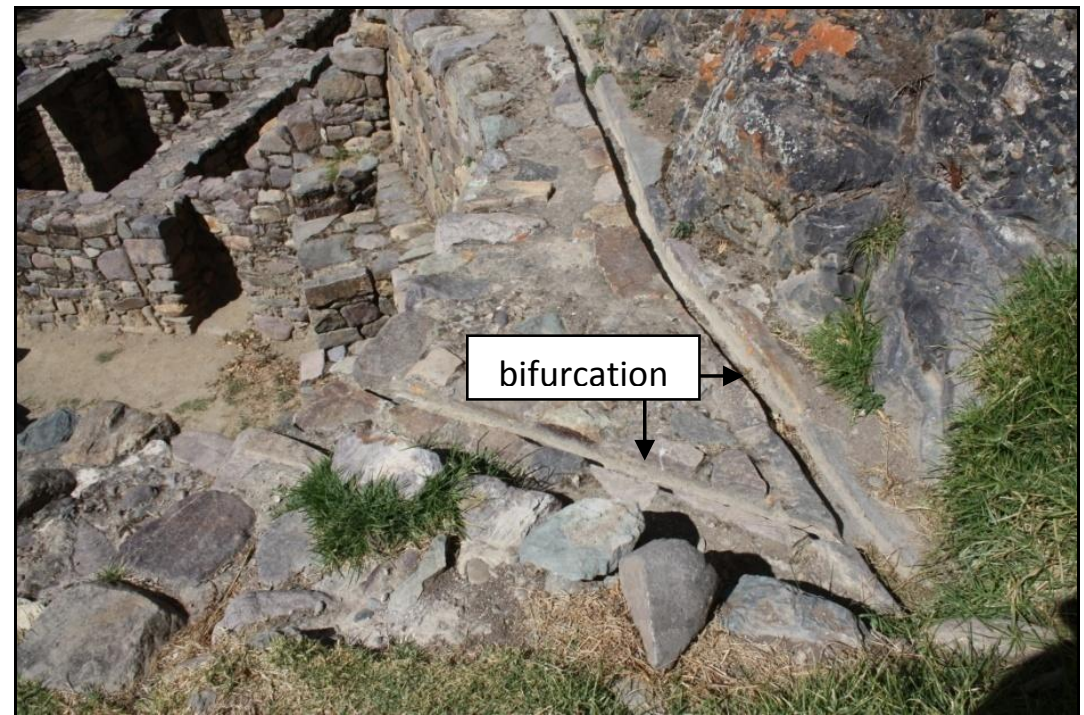

Figure 6: Bifurcation of Inkamisana Complex feed channel 


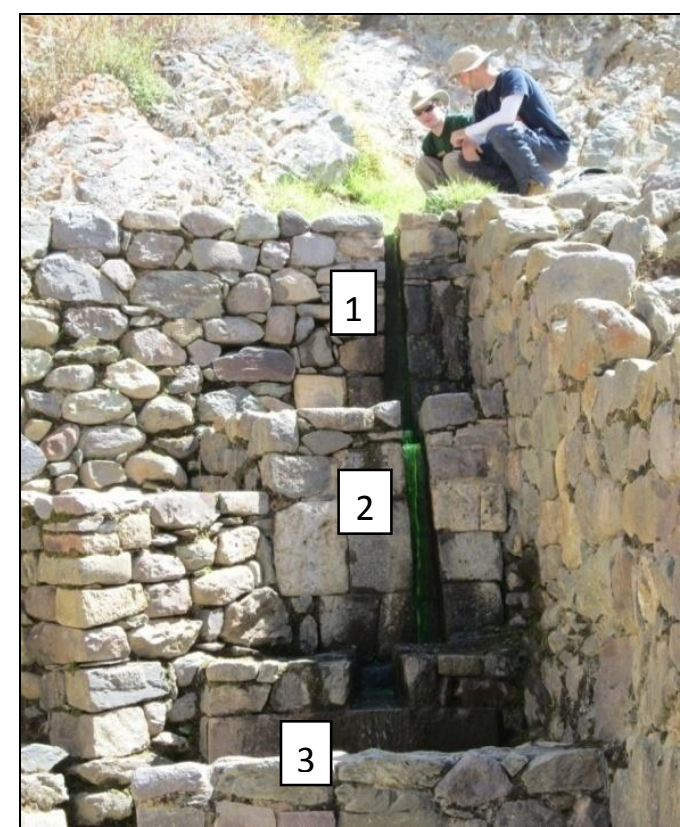

Figure 7: Fountains 1, 2, and 3

The other branch of the bifurcation feeds the section where Fountains 4A, 4B, and $4 \mathrm{C}$ are located. Fountains 4B and 4C are both unfinished and their exact location and behavior are currently hypothetical.

Figure 7 shows the front view of Fountain 4A. Figure 9 and Figure 10 show the front views of Fountains 4B and 4C. All three of these fountains have a cliff face as their back drop and the feed channel to each is carved along the edge of the rock formation.
These first three fountains are unique compared to the rest of the fountains on site. Instead of having a jet flow behavior, Fountains 1, 2, and 3 have sheeting flow. This picture was taken during a dye trace experiment that showed the path of water after it exits Fountain 3.

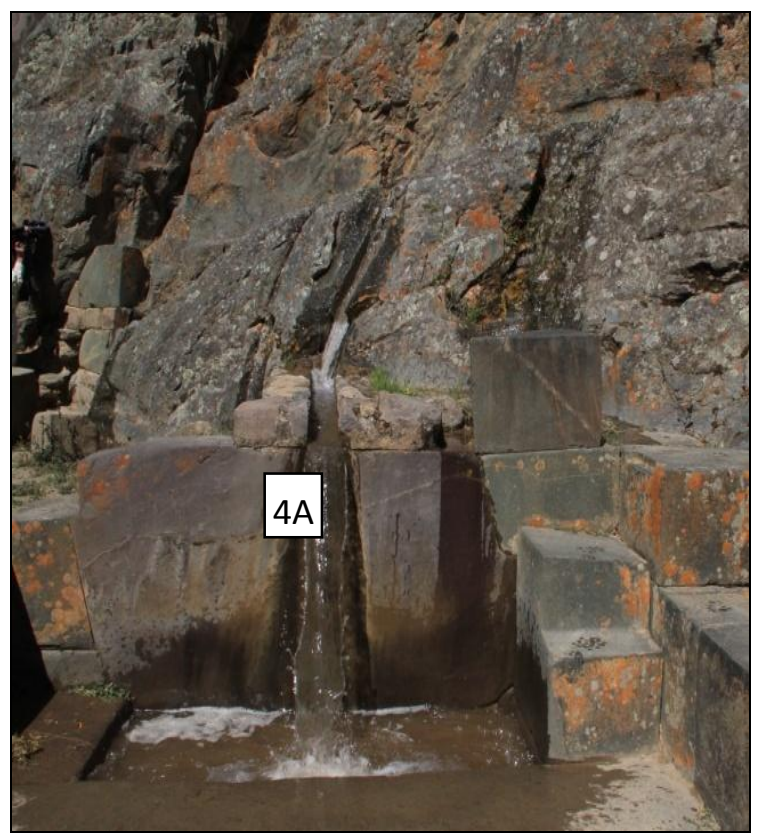

Figure 8: Fountain 4A 


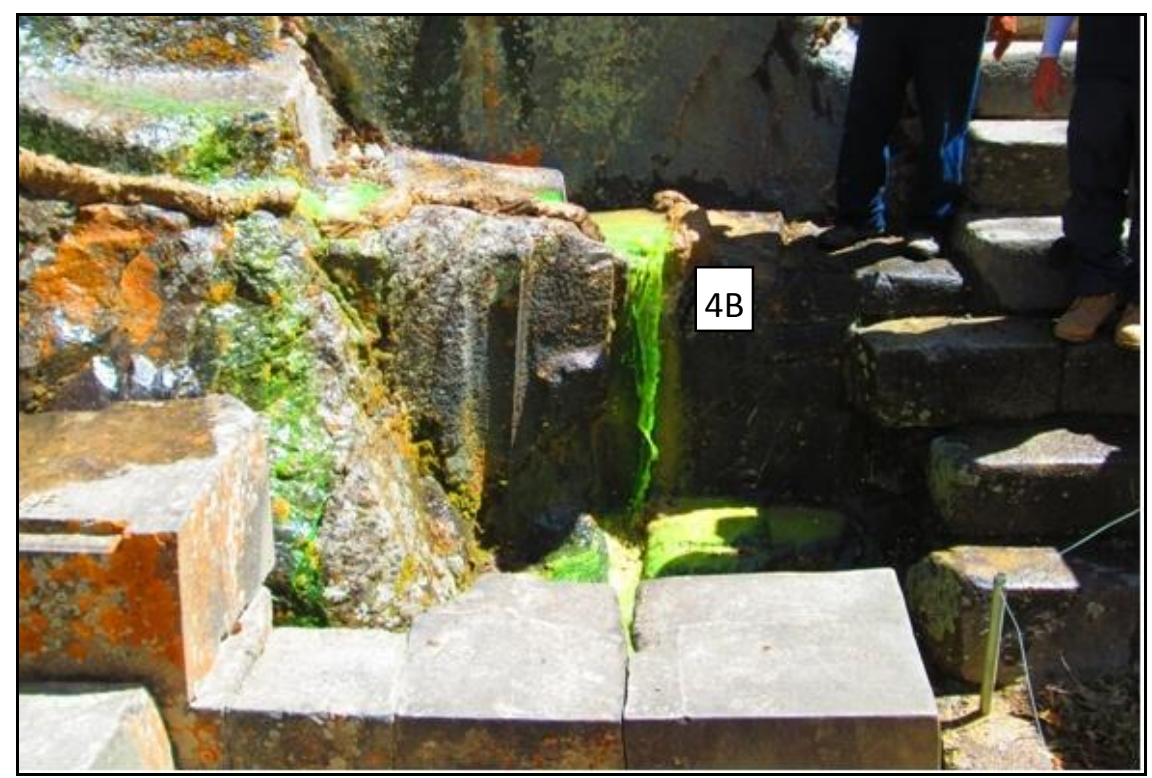

Figure 9: Unfinished Fountain 4B

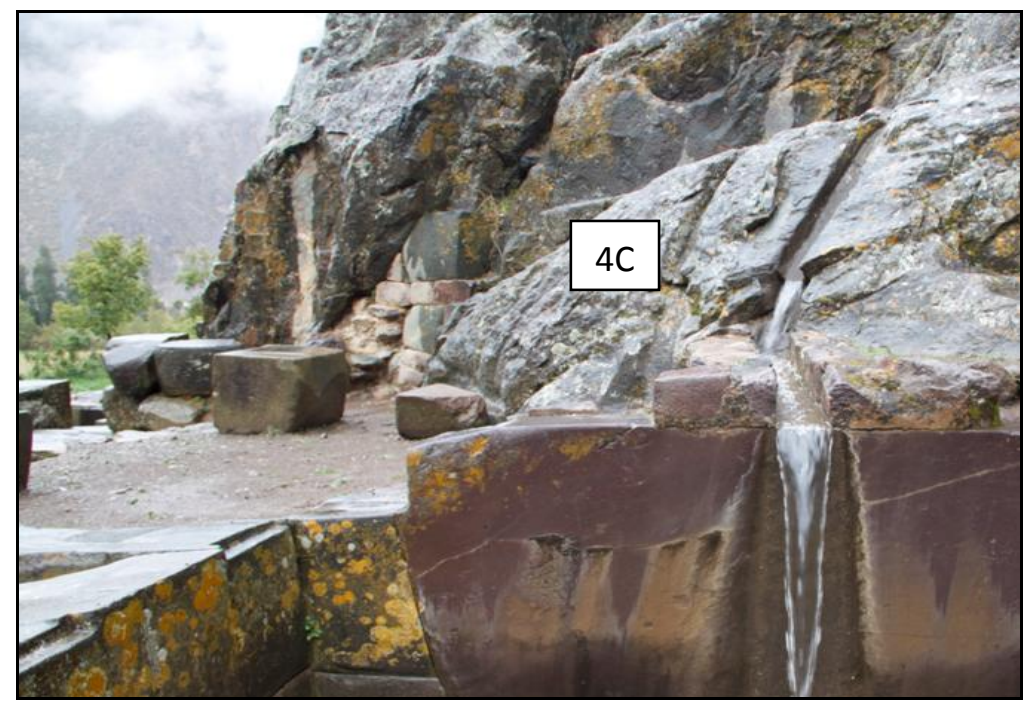

Figure 10: Unfinished Fountain 4C
Fountain $4 \mathrm{~B}$ is not currently functional. Either construction was unfinished or channel walls previously collapsed. Behavior was simulated by constructing artificial channel walls with clay lining. The flow path of its fed channel was estimated based on the location of groves in the rock formation.

The outflow from Fountains 4A and 4B join the outflow of Fountain 3. Outflow from Fountain 4C, if finished, would have joined this channel approximately 10 meters further down site. These first six fountains surround an area filled with the remains of house walls and ceremonial rocks.

Near Channel C7 a channel split occurs. Initially it was believed that a thin rock was used to split flow to Conduits 1 and 2. However, Dr. Oviedo said this was a temporary fix and that the split would have occurred further downstream by creating two distinct channels, each with separate walls. The third control volume, or the Lower Misana, begins after these three outflows join. 


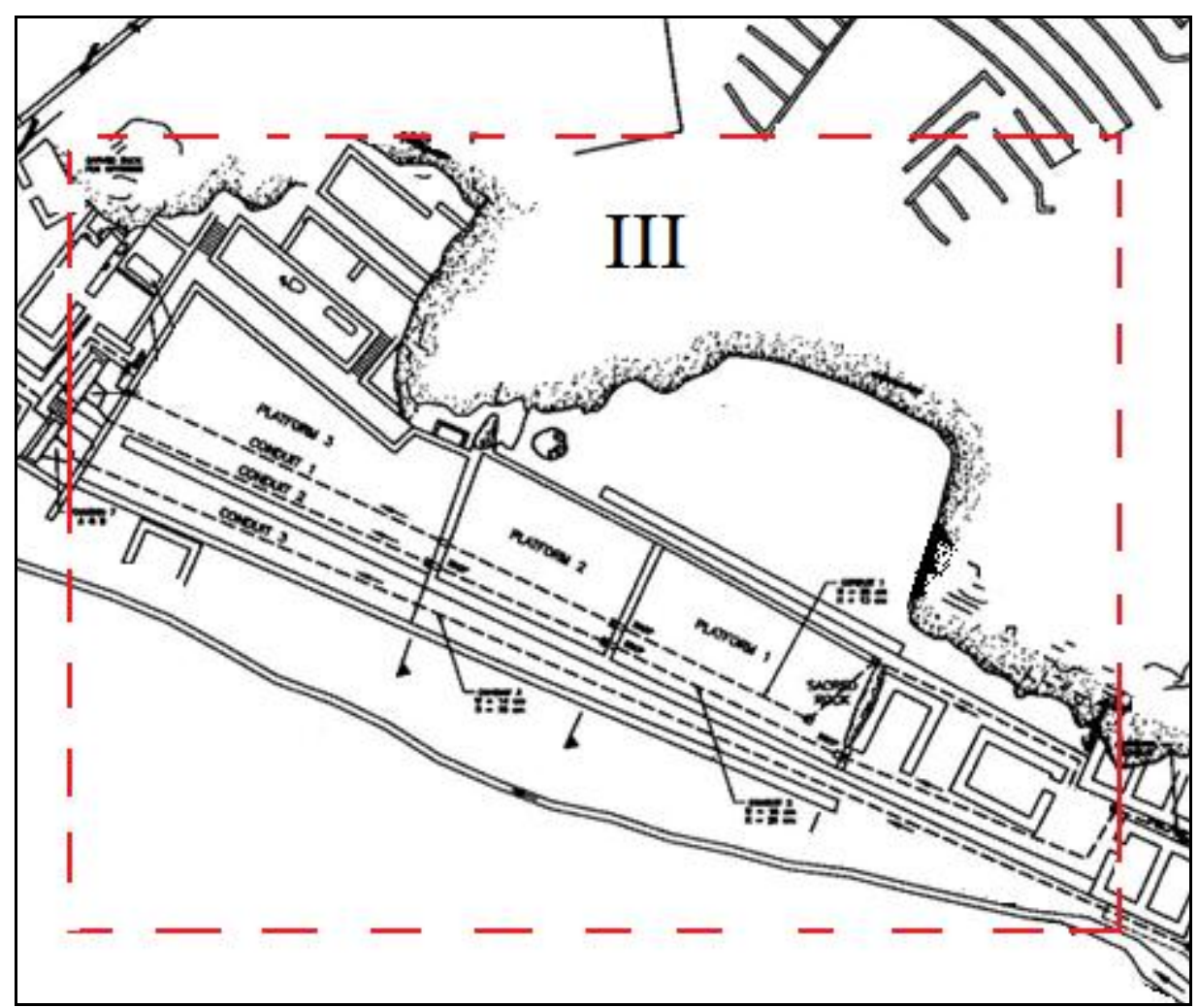

Figure 11: Control Volume III

A second source to the site, the Manyaraki Canal, enters control volume III. Three larger channels (referred to as Conduits 1,2 and 3) transport both sources of water to Fountains 6A, 6B, 7A, and 7B located at the far south end of the Inkamisana Complex. Unfinished Fountains 5A and 5B would have been fed by these conduits if complete. These conduits traverse three large grassy areas or platforms and a large Sacred Rock. At the end of each platform there are multiple drop structures and a level change of approximately one meter. Figures 12 and 13 show these drop structures.

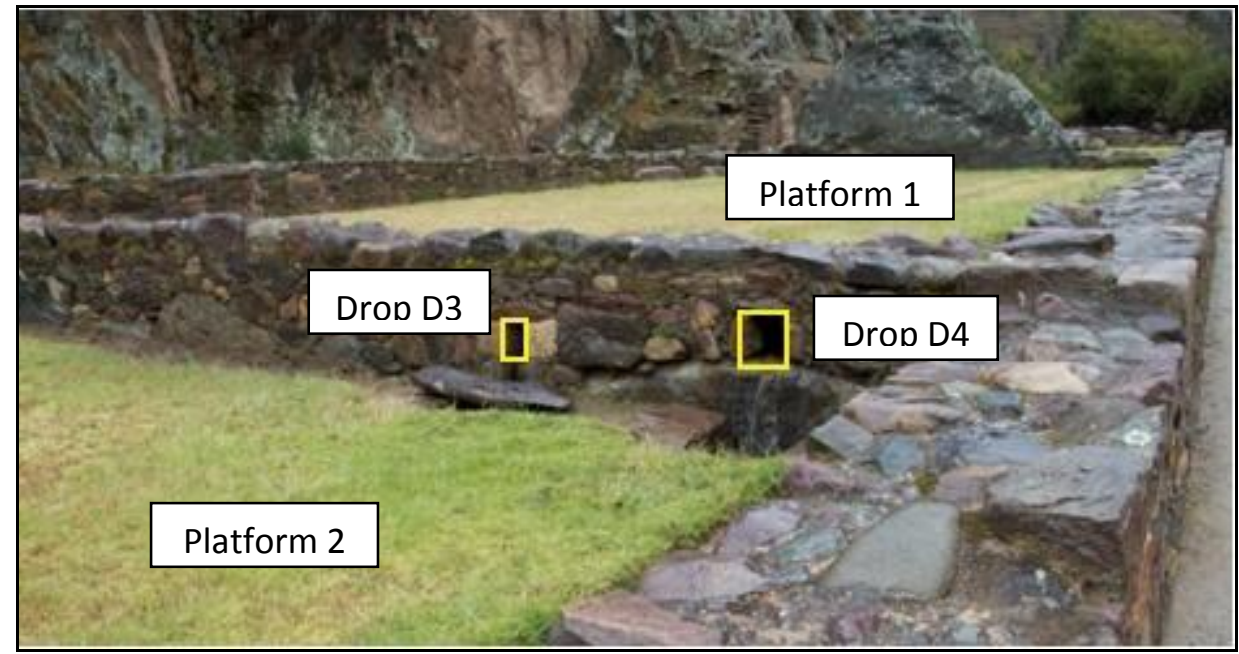

Figure 12: Drop Structures D and E
There are two drop structures, D3 and D4, that allow flow in Conduits 1 and 2 to drop from Platform 1 to Platform 2. At the base of each drop, water falls into a basin and then continues its flow through Platform 2. 


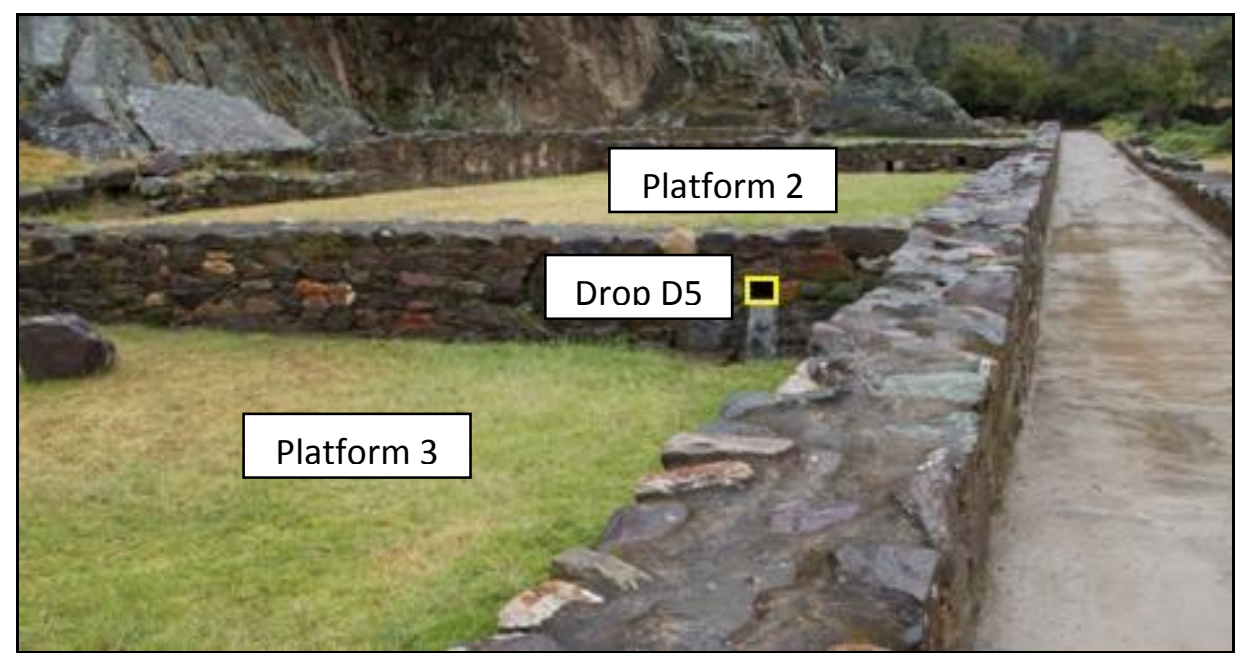

There is one drop, D5, visible where Platforms 2 and 3 meet. This drop allows flow from in Conduit 2 to fall into a basin and then continue underneath Platform 3.

Figure 13: Drop Structure F

The three conduits are sub grade; two travel under the three platforms and the third under a walkway adjacent to the platforms. Conduit 2 feeds Fountains $6 \mathrm{~A}$ and 6B while Conduit 3 feeds Fountains 7A and 7B. Conduit 1 currently spits out at the side of Fountain $6 \mathrm{~A}$ and is likely the intended feed to unfinished Fountains 5A and 5B (Figure 16). The three sets of fountains flow into separate catch basins. Outflow to each of these basins gathers into one channel that then feeds control volume 4, or the Fountain House Complex.

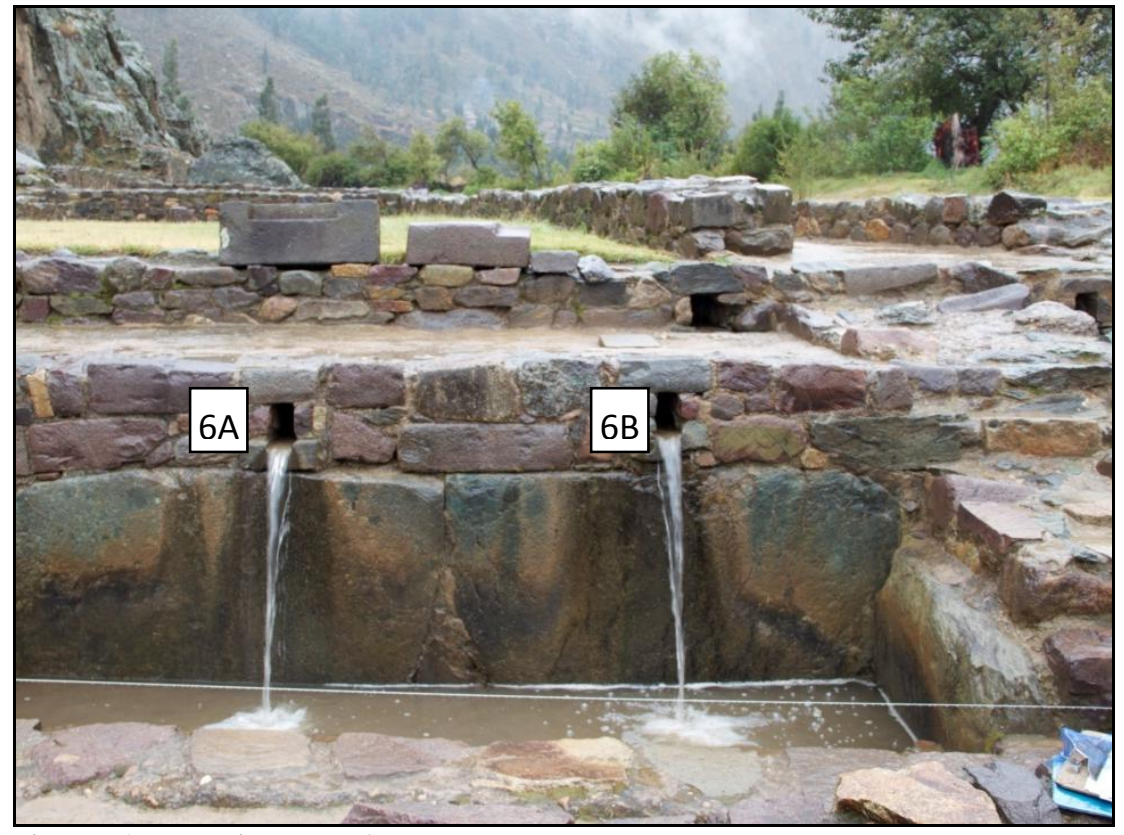

Fountains 6A and 6B are at approximately the same height. The catch basin is slightly sloped to the right. This drains the water through an orifice and into an underground channel.

Figure 14: Fountains 6A and 6B 


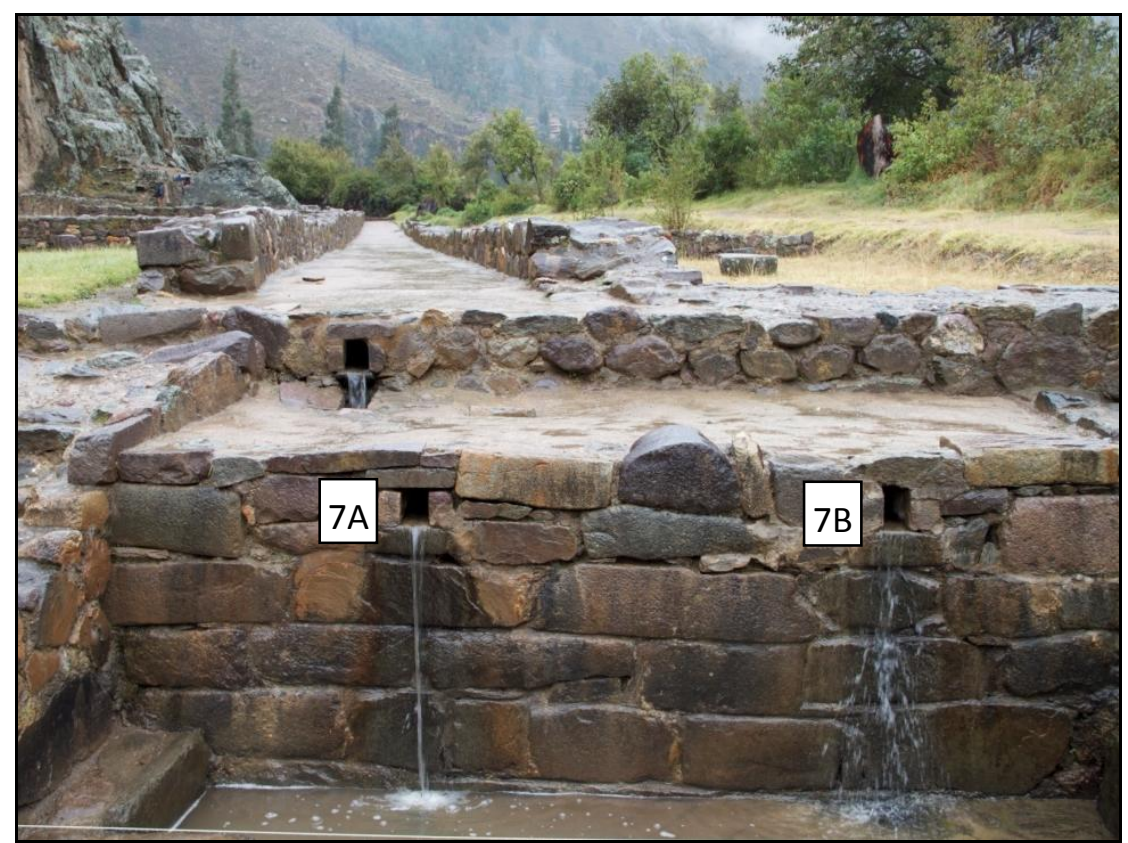

Figure 15: Fountains 7A and 7B

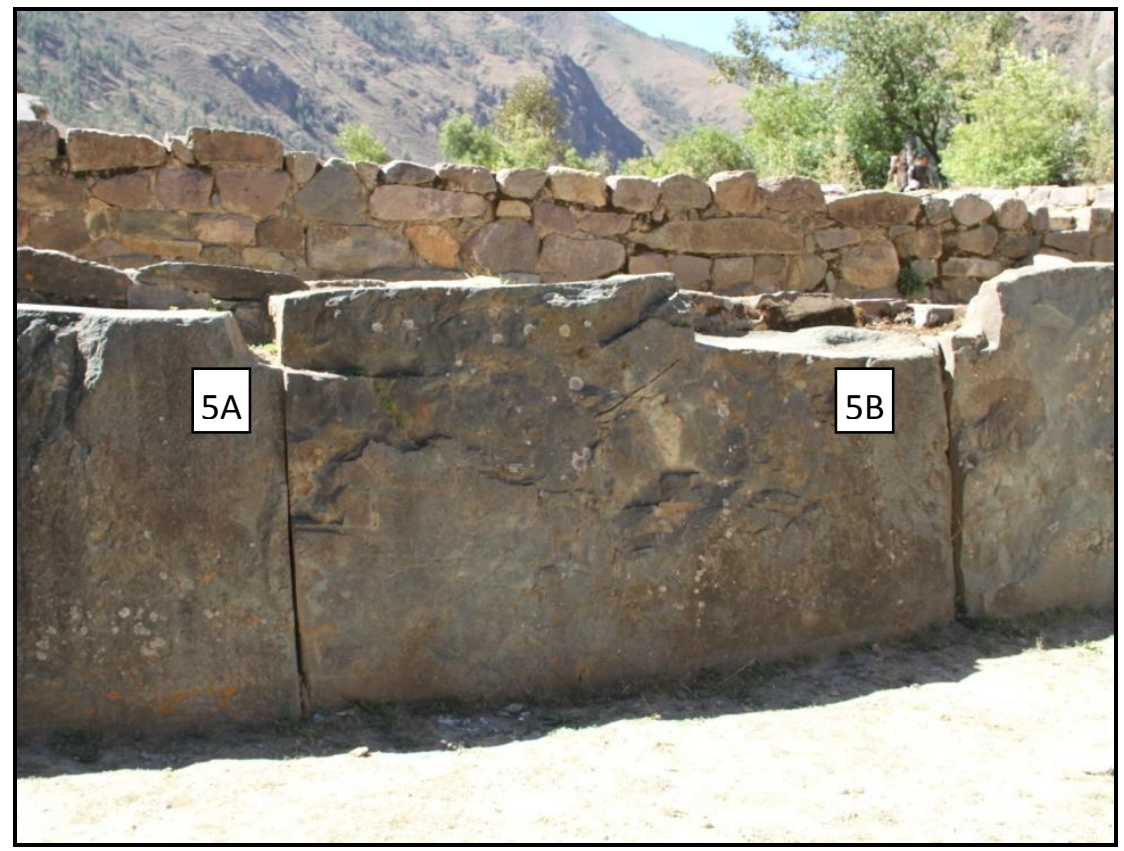

Figure 16: Unfinished Fountains 5A and 5B
Fountains 7A and 7B are at approximately the same height. The catch basin is slightly sloped to the left. This drains the water through an orifice and into an underground channel.

Fountains 5A and 5B are unfinished. The layout of these fountains is similar to Fountains 6A, 6B, 7A, and 7B. There is an orifice at the right edge of the catch basin. This feeds an underground channel that connects to the adjacent basins' outflow channels. 


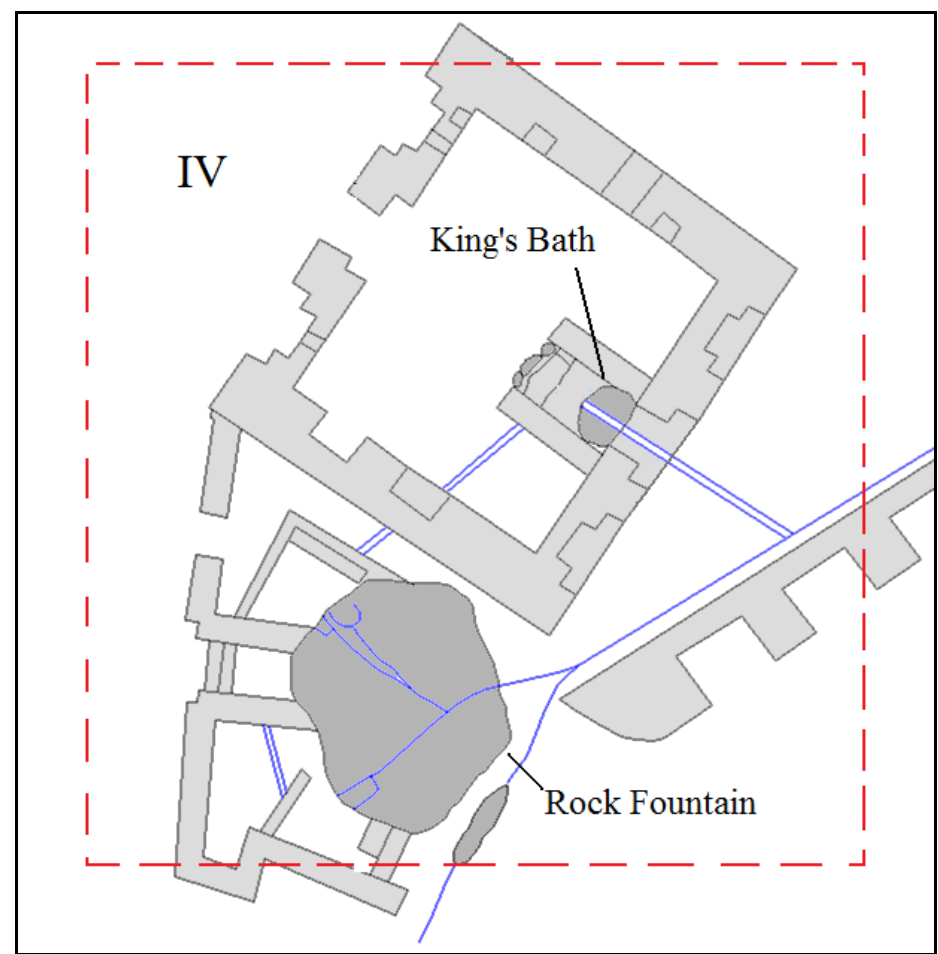

Figure 17: Control Volume 4
Two fountain structures are located in Control Volume IV: the King's Bath and the Rock Fountain. A large and elegant structure called the Fountain House encloses the King's Bath. Adjacent to this building is a massive rock with three fountain channels carved into its top face. The outflow from the King's Bath and Rock Fountain then exit the site via underground channels.

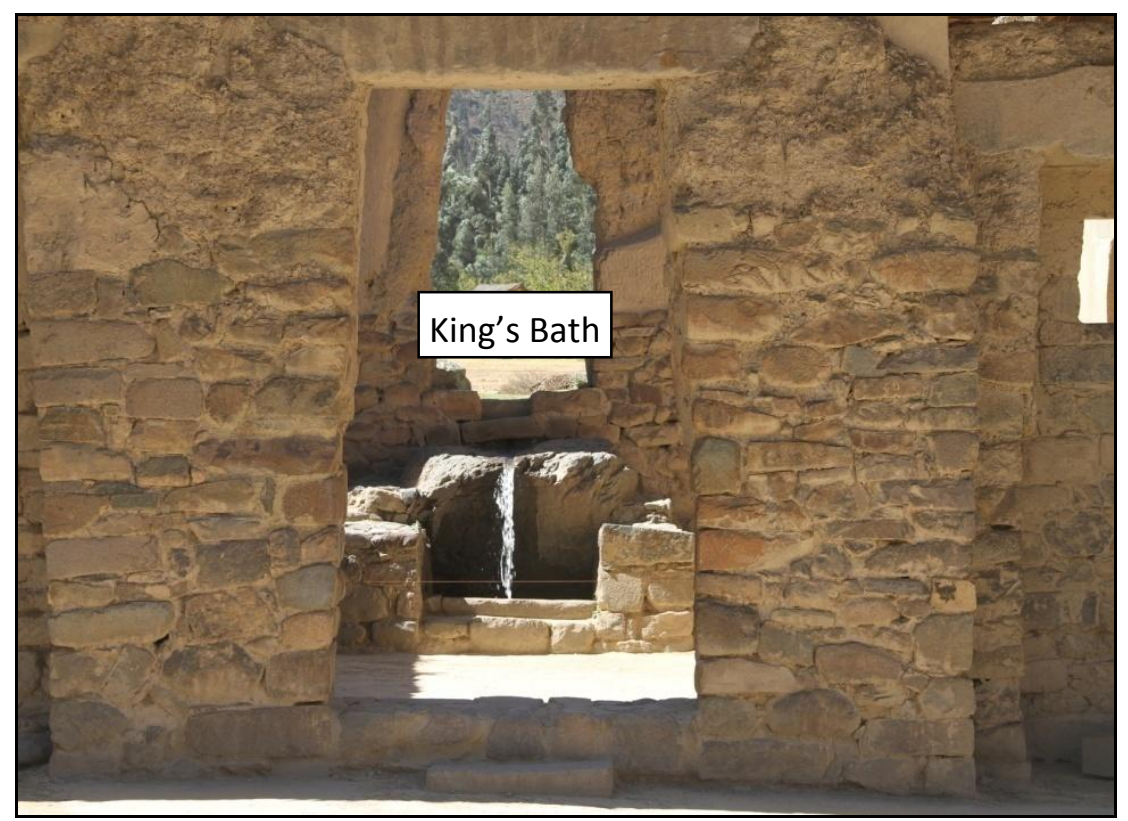

Figure 18: The Fountain House and King's Bath
The Fountain House was designed with several large windows that provide a view of the surrounding mountainside. This fountain has a similar design to Fountain 4A and the Upper and Princess Fountains. 


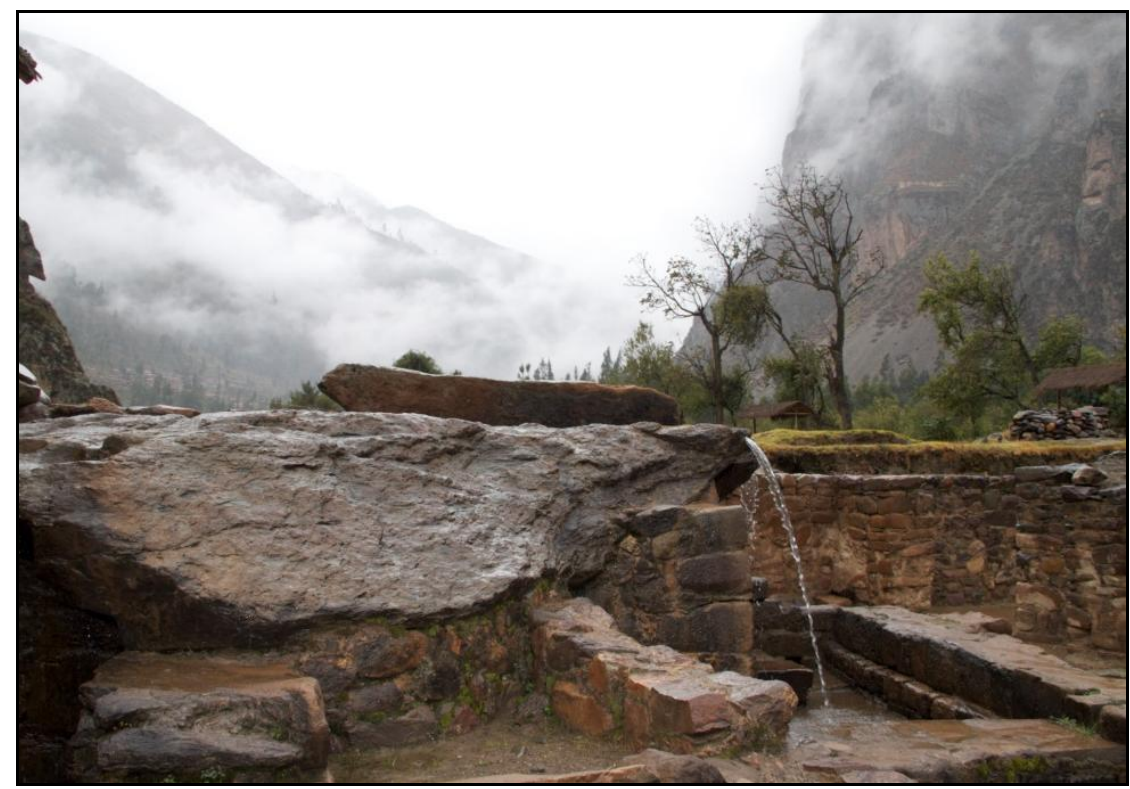

A view of the Rock Fountain looking north, up the Patakancha Valley. The jet behavior of one of its fountains can be seen. The current feed for the Rock Fountain is a modern channel.

Figure 19: The Rock Fountain

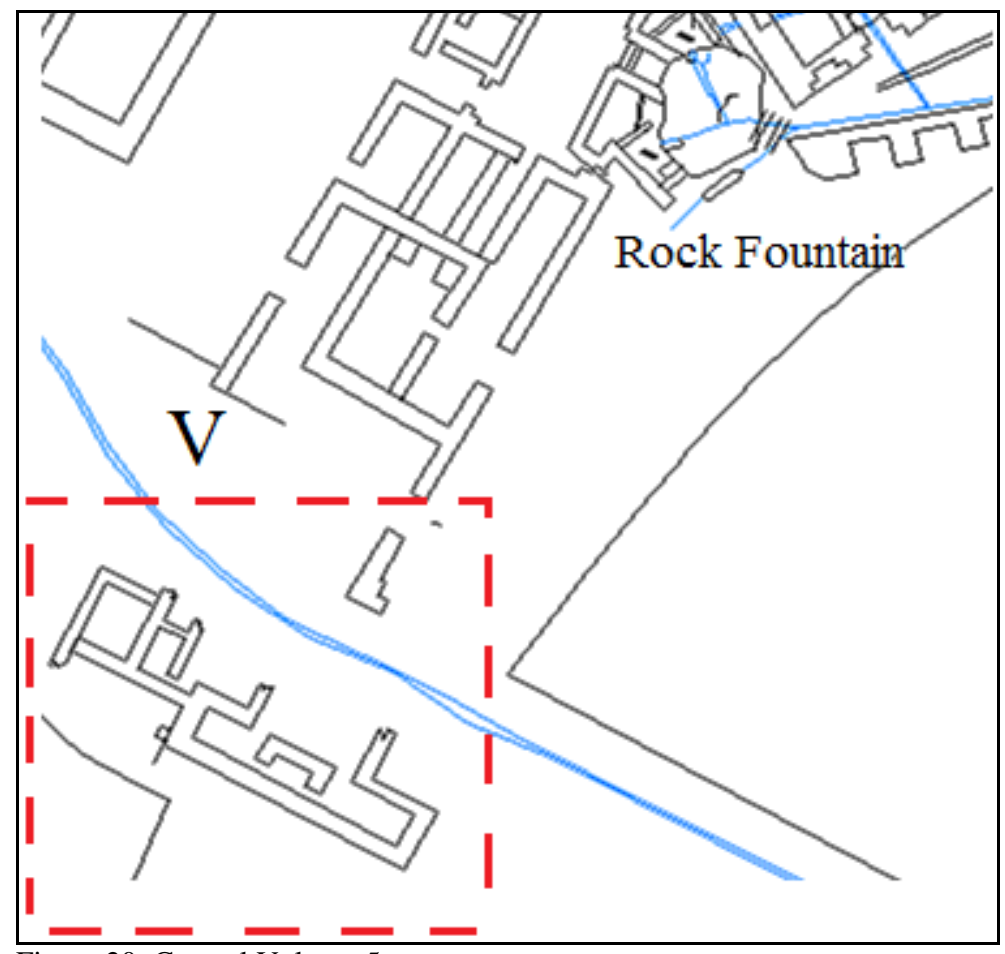

The final control volume, or Princess Fountain Complex, is independent of the first four control volumes. Built in the final stages of Inca occupancy, the two fountains located here are fed by the Manyaraki Canal. Water supplied by this canal flows through a buried channel that splits; one branch runs to the Upper Fountain and one to the Princess Fountain. The Princess Fountain has an elegant design and is one of the most famous Inca fountain in Peru. 


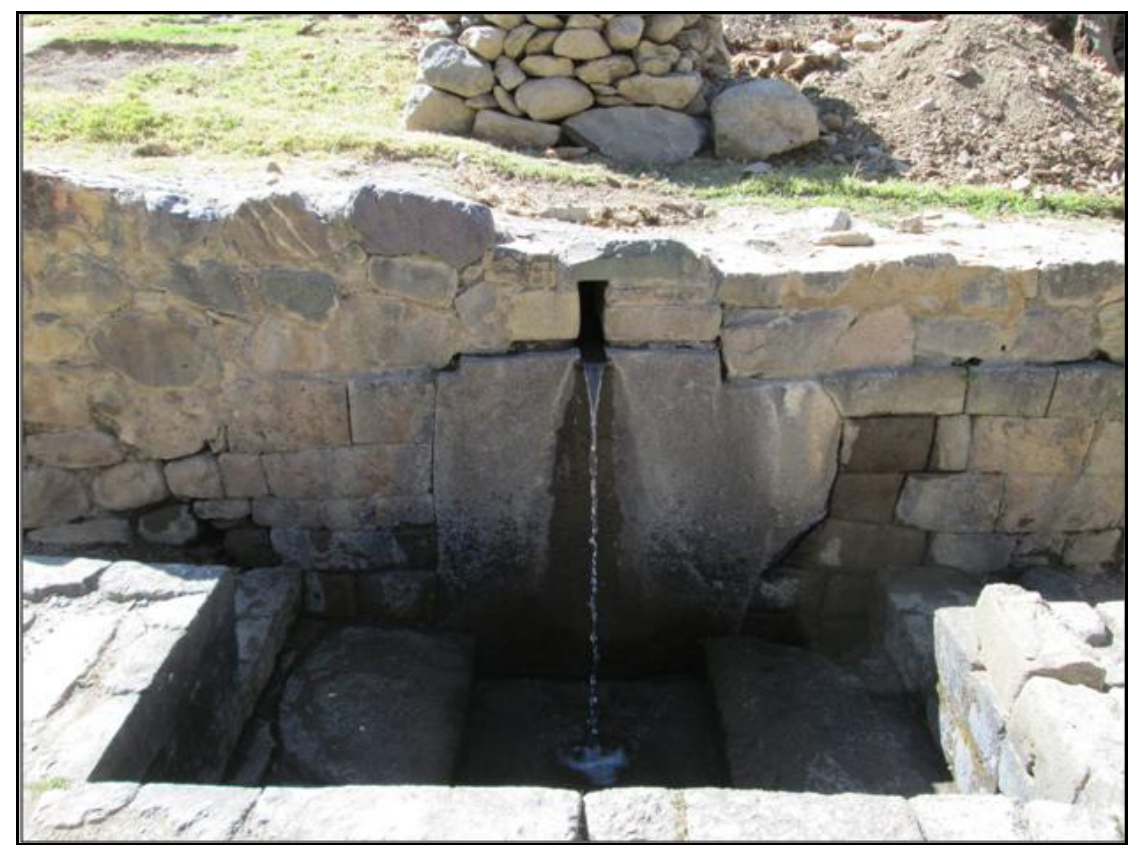

Figure 21: The Upper Fountain

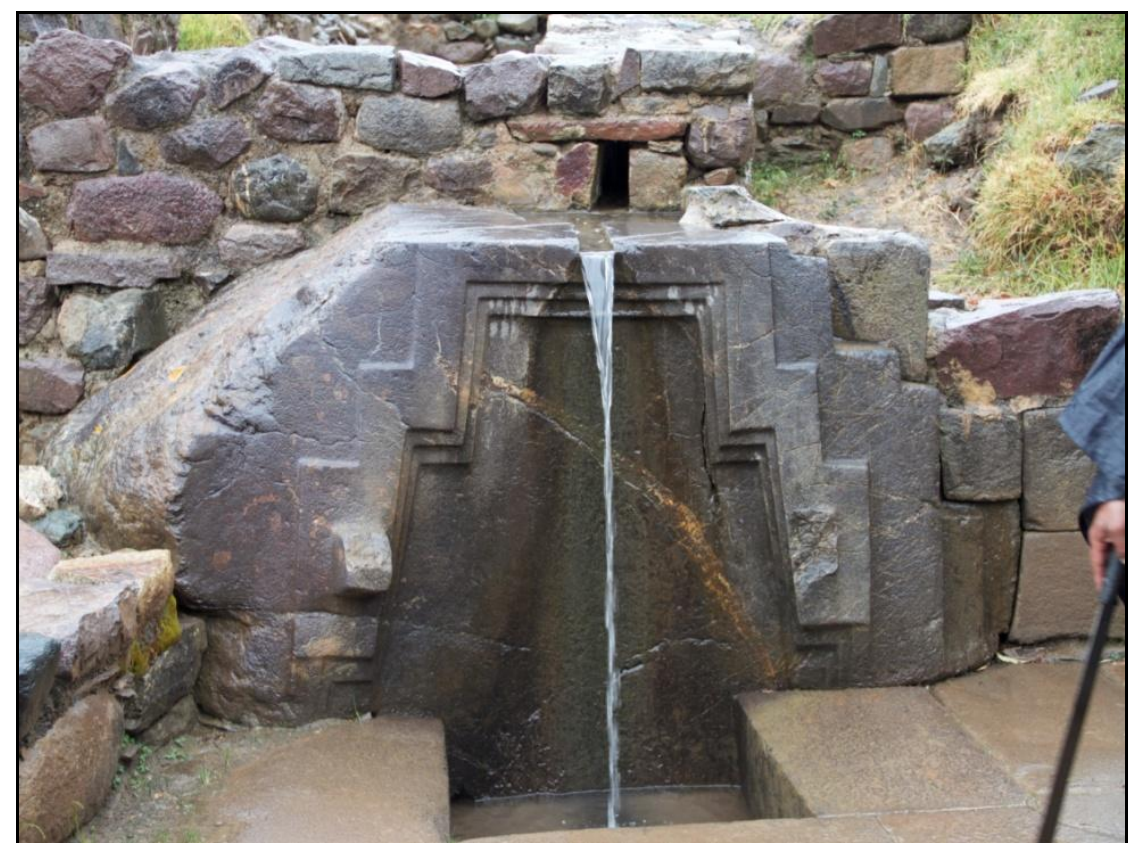

Figure 22: The Princess Fountain
The Upper

Fountain has a very large catch basin. This fountain is similar to Fountains 6A, 6B, 7A, and 7B in that its feed channel is buried. The face of the fountain is flush with the adjacent wall.

The Princess

Fountain has a series of four indentations carved into its front face. The design of the fountain is precise and distinguishes it from other fountains on site. 
The location of the Princess Fountain and Upper Fountain relative to the Rock Fountain and Fountain House is shown in Figure 23.

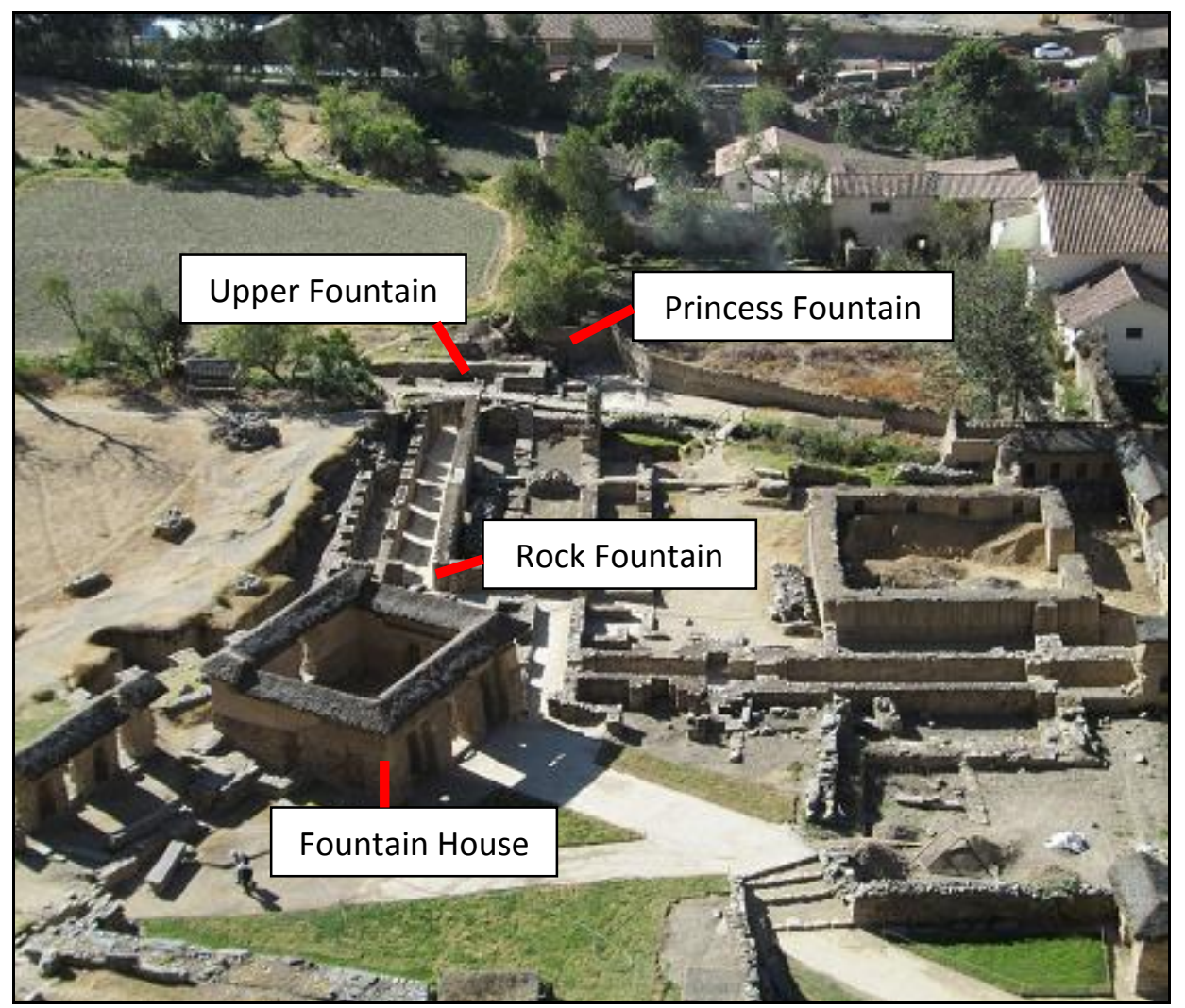

Figure 23: Aerial view of Fountain House Complex

An aerial view of the Fountain House Complex and Princess Fountain Complex shows the relative location of all four fountain structures. There is continued excavation around this area and many ruins have already been found. To the left of the Fountain House is a large field that is currently used for ceremonial celebrations. It stretches from the lower end of the Inkamisana to the Fountain House. The ground level of the field during Inca inhabitance was approximately 8 feet below the current grade. Sometime in the 1600's a flood through the valley caused sediment to deposit over this field.

The location of channels in each of the five control volumes can be found in Figures 24 and 25 (Figure 25 is not to scale since the extent of the site is so large). Note, Channels C10, C11, and $\mathrm{C} 12$ correspond to conduits 1,2, and 3 respectively. All channel design parameters (channel slope, depth, height, roughness coefficient) are compiled in Table 1 shown in the Data section. 


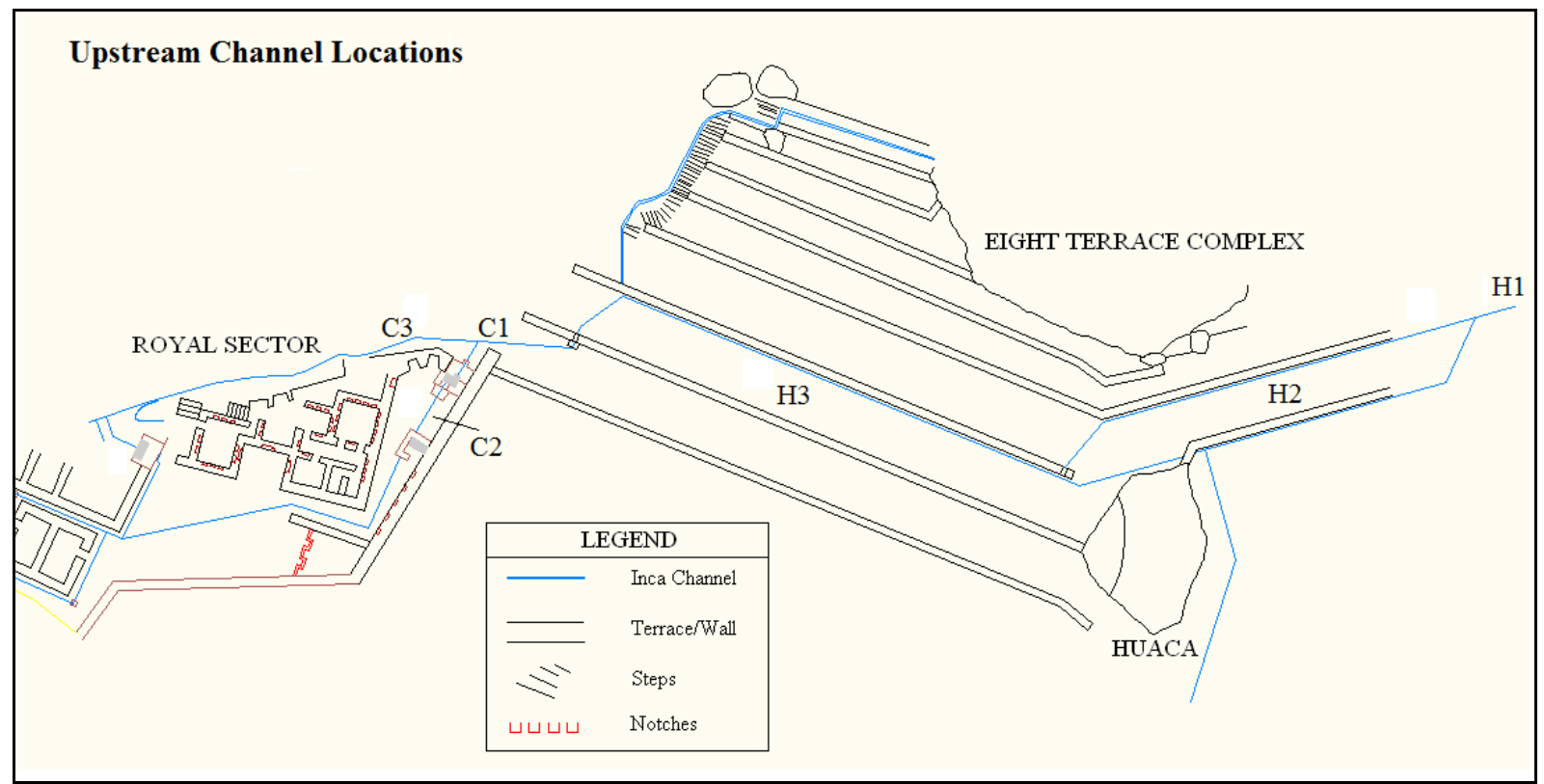

Figure 24: Channel Locations in control volumes 1-2

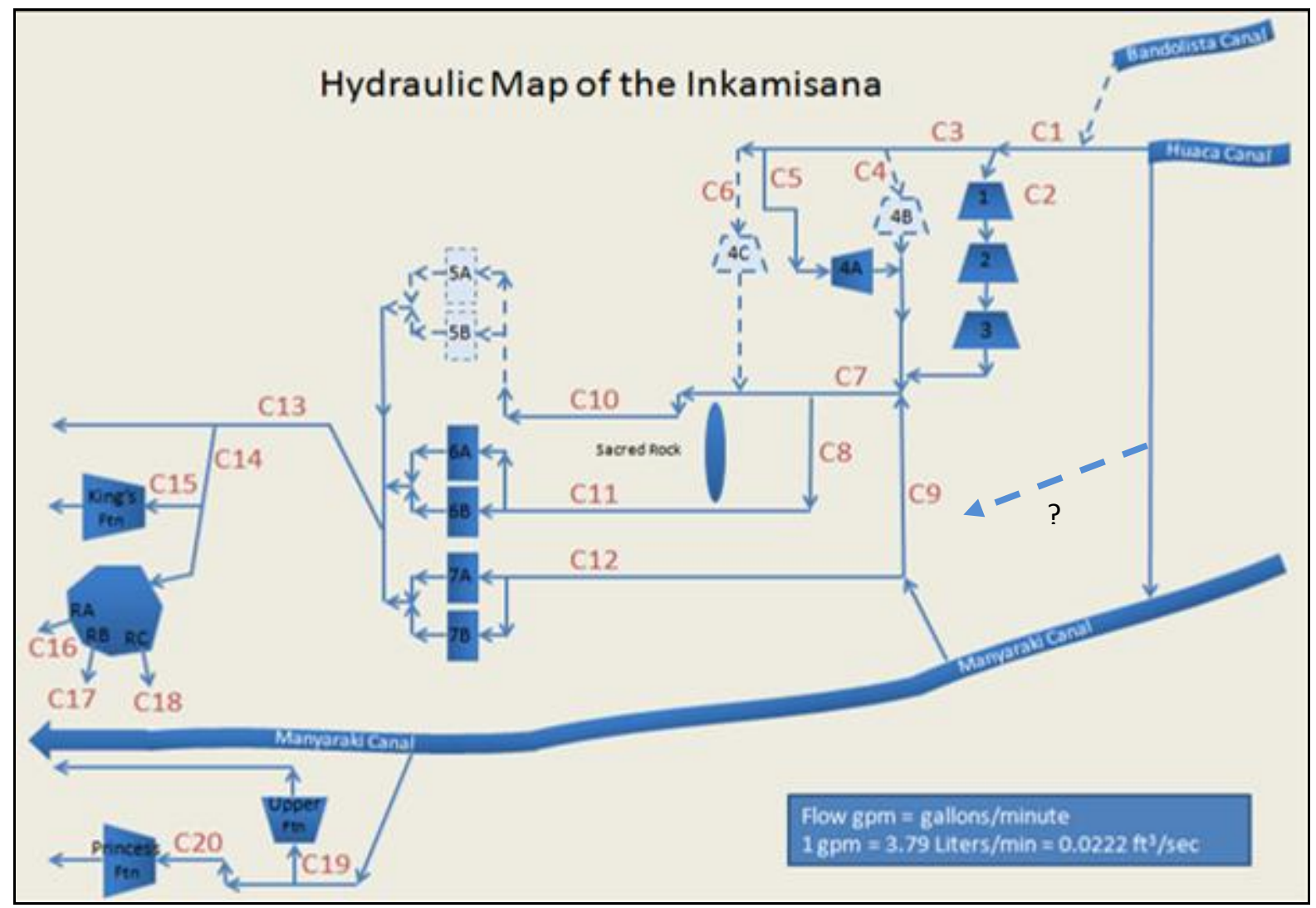

Figure 25: Channel locations in control volumes 2-5 


\section{Field Methods}

\section{Approach}

To understand the design aspects of the site, the research team looked at how the Inca would have overcome specific obstacles when constructing the site. In order to build the ancient royal estate, they needed to find a permanent and reliable source of water. Since springs would not naturally and consistently yield a high enough flow the Inca had to build a system to collect and transport a reliable supply of water, most likely via a canal fed by the Patacancha River. To avoid seepage loss the channels were lined on three sides (or four if underground) with impervious stone slates. The motion of flow throughout the site should also be noted. Flow can be classified into two broad types: laminar or turbulent. A dimensionless parameter called the Reynolds number can be used to understand what type of flow will occur in a channel based upon its geometry:

$$
\operatorname{Re}=\frac{u \cdot L}{v}
$$

In this equation, $\mathrm{u}$ is the mean flow velocity, $\mathrm{L}$ is the characteristic length, and $\mathrm{v}$ is the kinematic viscosity of the fluid. The characteristic length depends on the system being analyzed. In the case of open channel flow, the hydraulic radius of the channel, $R_{H}$, is used. Reynolds numbers for open channel flow can be calculated using Equation 2, where $\mathrm{Q}$ is the flow rate in the channel and $\mathrm{A}$ is the cross sectional area of flow:

$$
R e_{\text {channel }}=\frac{4 \cdot Q \cdot R_{H}}{v \cdot A}
$$

Reynolds numbers greater than 2000 correspond to turbulent flow, values less than 500 correspond to laminar flow, and values in between correspond to the transitional zone (Chanson, 1999).

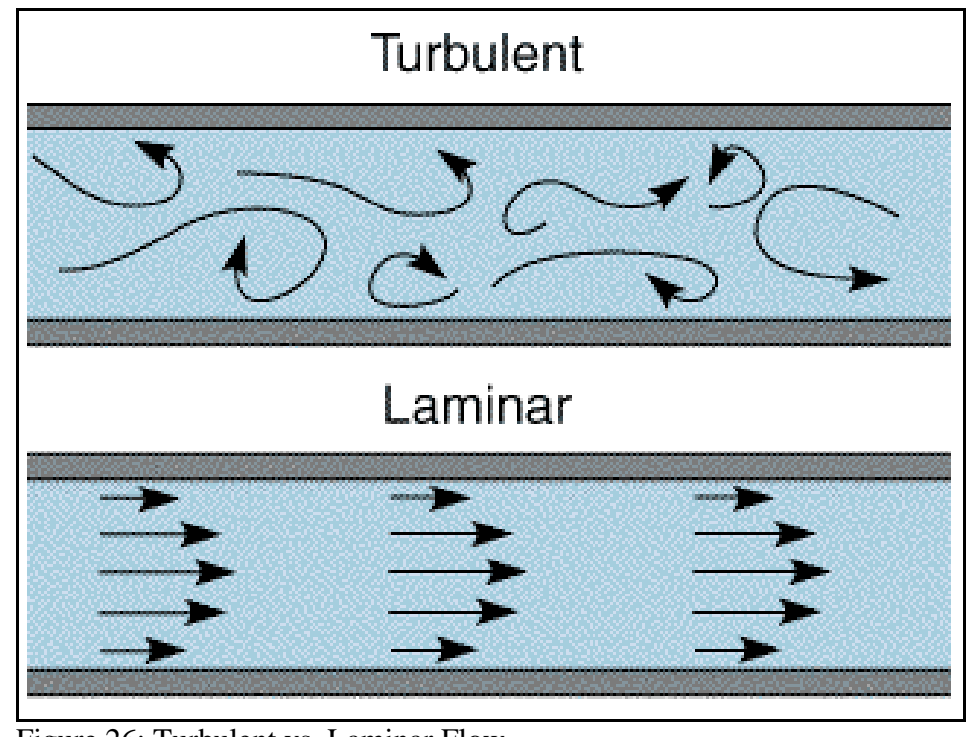

Figure 26: Turbulent vs. Laminar Flow
Turbulent flow paths are less ordered and cause eddies and swirls to form. There is rapid variation of velocity in the flow.

Laminar flow paths are straight and form parallel flow layers. Adjacent layers slide over each other. There is no disruption in the flow and thus no eddies or swirls. 
Kinematic viscosity measures how resistant a fluid is to deformation due to shear forces. Water has a relatively low kinematic viscosity compared to other fluids, and its value decreases as temperature increases:

Table 1: Viscosity of Water vs. Temperature

\begin{tabular}{|c|c|c|}
\hline $\begin{array}{c}\text { Temperature, } \mathrm{T} \\
\left({ }^{\circ} \mathrm{C}\right)\end{array}$ & $\begin{array}{c}\text { Dynamic Viscosity, } \mu \\
\left(\mathrm{Pa} \mathrm{s}, \mathrm{N} \mathrm{s} / \mathrm{m}^{2}\right) \times 10^{-3}\end{array}$ & $\begin{array}{c}\text { Kinematic Viscosity, } v \\
\left(\mathrm{~m}^{2} / \mathrm{s}\right) \times 10^{-6}\end{array}$ \\
\hline 0 & 1.79 & 1.79 \\
\hline 5 & 1.52 & 1.52 \\
\hline 10 & 1.31 & 1.31 \\
\hline 20 & 1.00 & 1.00 \\
\hline 30 & 0.798 & 0.801 \\
\hline 40 & 0.653 & 0.658 \\
\hline 50 & 0.547 & 0.553 \\
\hline 60 & 0.467 & 0.475 \\
\hline 70 & 0.404 & 0.413 \\
\hline 80 & 0.355 & 0.365 \\
\hline 90 & 0.315 & 0.326 \\
\hline 100 & 0.282 & 0.290 \\
\hline
\end{tabular}

Another potential hindrance to flow is sediment buildup. If dirt and debris collect in a channel, its carrying capacity greatly decreases. Once one or more channels stop functioning properly, the behavior of the entire flow network is greatly affected. The Inca, however, were able to design channels to carry flows that would prevent such buildup.

The study of sediment transport in an open channel can be used to model this phenomenon. For sediment transport, the Reynolds number of particles in the flow, $\mathrm{Re}_{*}$, is compared to the Shields parameter of the flow, $\tau_{*}$, (Chanson, 1999). The particle Reynolds number is a ratio of the viscous and inertial forces acting on the particle, both related to flow velocity. Shear velocity also had to be calculated in order to estimate both these parameters. Shear velocity is used to express the effect of shear forces on the motion of a fluid in terms of a velocity. These three parameters can be calculated as:

$$
\begin{aligned}
& V_{*}=\sqrt{g \cdot R_{H} \cdot \sin \theta} \\
& \tau_{*}=\frac{V_{*}^{2}}{(s-1) \cdot g \cdot d_{s}} \\
& R e_{*}=\frac{V_{*} \cdot d_{s}}{v}
\end{aligned}
$$

3

Once $\tau_{*}$ and $\mathrm{Re}_{*}$ are calculated, sediment motion can be predicted by comparing these values to the Shields diagram. The Shields diagram relates the relationship of $\tau *$ and $\operatorname{Re} *$ to behavior of sediment from a series of flume tests: 


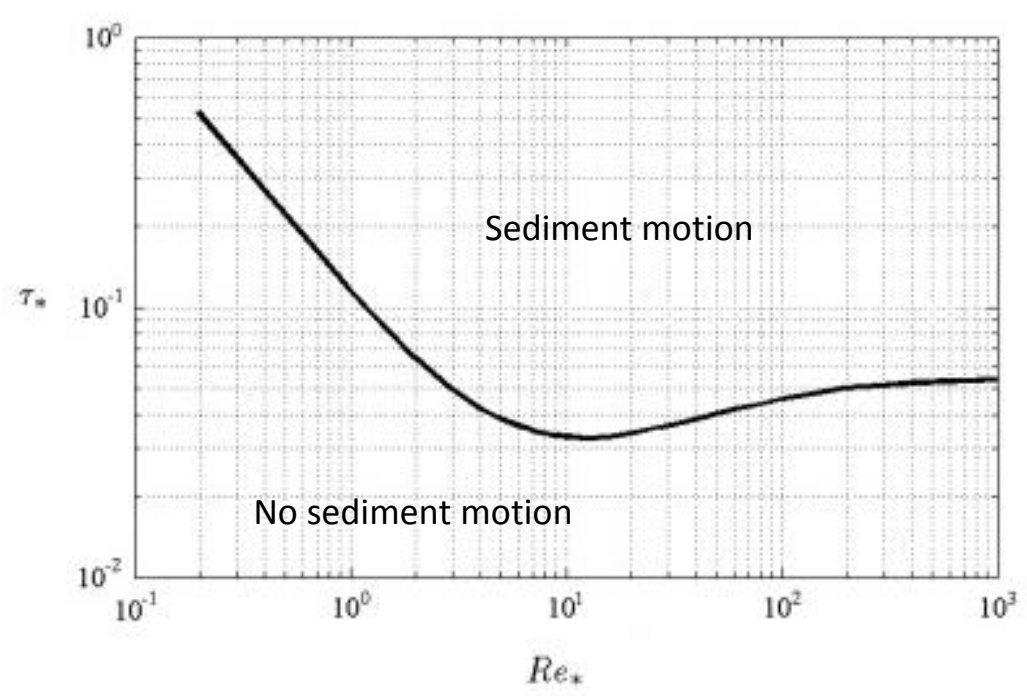

Figure 27: Particle Reynolds number vs. Shields parameter (Guo, 2002)

Coordinates that fall above the critical movement curve correspond to sediment motion, whereas below the curve represents no sediment motion.

Another method for estimating the self-cleaning property of an open channel was studied in a paper on aquaculture engineering (Timmons et al, 1991). Timmons and Youngs developed an equation based upon the properties of sediment present:

$$
v_{\text {olean }}=0.5 \cdot d^{.444}(G-1)^{0.5}
$$

In this equation $\mathrm{d}$ is the particle diameter in $\mathrm{mm}, \mathrm{v}$ is minimum cleaning velocity in $\mathrm{ft} / \mathrm{s}$, and $\mathrm{G}$ is the specific gravity of the sediment. This method is a simplification of sediment transport equations, and was applied specifically to sediments with specific gravity between 1.83 and 2.64. Timmons and Youngs used this equation as a first estimate of cleaning velocity for fish feces and uneaten food (Timmons et al, 1991).

Carrying capacity is another important design aspect of a channel. The slope and geometry of a channel directly affect the velocity and flow rate of water it can carry. At this site, channel slopes range from 1 to 7 percent. Carrying capacity for each channel was calculated using a flow depth equal to 0.5 and 0.8 the total channel depth. These two depths were used as a factor of safety in order to account for splashing and to avoid overflow. Manning's method, Equations 7 and 9, for open channel flow was used to calculate these properties:

$$
\begin{aligned}
& \bar{V}=\frac{1}{n} \cdot R_{H}^{2 / 3} \cdot s^{1 / 2} \\
& Q=\bar{V}_{1} \cdot A_{1}=\bar{V}_{2} \cdot A_{2}
\end{aligned}
$$




$$
\begin{aligned}
& Q=\frac{1}{n} \cdot A \cdot R_{H}{ }^{2 / 3} \cdot s^{1 / 2} \\
& \text { where } R_{H}=\frac{\left(w * y_{n}\right)}{\left(w+2 \cdot y_{n}\right)}
\end{aligned}
$$

In Equation 7, $\bar{V}$ represents the uniform flow velocity in $\mathrm{m} / \mathrm{s}, \mathrm{n}$ is a coefficient that relates the roughness of a channel's lining, $\mathrm{R}_{\mathrm{H}}$ is hydraulic radius, and $\mathrm{s}$ is the slope of the channel bed.

Assuming constant shear stress as the boundary assumption, hydraulic radius is the ratio of cross-sectional flow area to wetted perimeter (Note: for wide channels, $w>10 y_{n}$, hydraulic radius can be approximated by flow depth). It is used as a measure of 'flow efficiency' which then helps assess a channel's capacity and is an important metric in relating the design of varied channel geometry. The greater the hydraulic radius, the great the efficiency of a channel and thus the more flow it can carry. For a given channel width, the hydraulic radius of a channel increases as channel depth increases.

Table 2 shows a chart of Manning's roughness coefficient, $n$, for various materials. Channels that are lined with smoother surfaces have a lower roughness coefficient than natural channels, lined with gravel or weeds.

Table 2: Manning's Coefficient, $\mathrm{n}$, for various materials

\begin{tabular}{|l|c|}
\hline \multicolumn{2}{|c|}{ TYPICAL VALUES OF ROUGHNESS COEFFICIENT, MANNING'S $n$} \\
\hline Lined Canals & $\boldsymbol{n}$ \\
\hline Cement plaster & 0.011 \\
\hline Untreated gunite & 0.016 \\
\hline Wood, planed & 0.012 \\
\hline Wood, unplanned & 0.013 \\
\hline Concrete, troweled & 0.012 \\
\hline Concrete, wood forms, unfinished & 0.015 \\
\hline Rubble in cement & 0.020 \\
\hline Asphalt, smooth & 0.013 \\
\hline Asphalt, rough & 0.016 \\
\hline Corrugated metal & 0.024 \\
\hline Unlined Canals & $\boldsymbol{n}$ \\
\hline Earth, straight and uniform & 0.023 \\
\hline Earth, winding and weedy banks & 0.035 \\
\hline Cut in rock, straight and uniform & 0.030 \\
\hline Cut in rock, jagged and irregular & 0.045 \\
\hline
\end{tabular}


Table 3 continued: Manning's Coefficient, $n$, for various materials

\begin{tabular}{|l|c|}
\hline Natural Channels & $\boldsymbol{n}$ \\
\hline Gravel beds, straight & 0.025 \\
\hline Gravel beds plus large boulders & 0.040 \\
\hline Earth, straight, with some grass & 0.026 \\
\hline Earth, winding, no vegetation & 0.030 \\
\hline Earth, winding, weedy banks & 0.050 \\
\hline Earth, very weedy and overgrown & 0.080 \\
\hline
\end{tabular}

In Equation 8, Q represents flow rate in volume/time. This equation shows that if the cross sectional area of a channel decreases, the flow velocity must increase in order to account for flow rate continuity. Equation 9 combines Manning's Equation with the Continuity Equation. An expanded derivation of Manning's Equation can be seen in Figures 28 and 29.

where $F_{1}$ and $F_{2}$ are the hydrostatic forces, $\tau_{w}$ is the shear stress between the water and the channel perimeter, $P$ is the perimeter of the channel, $W$ is the weight of the water in the channel segment $(\gamma L A)$, and $\theta$ is the slope angle of the channel. Since the flow in the channel is uniform, $y_{1}=y_{2}, F_{1}=F_{2}$, and $V_{2}=V_{1}$. For small slopes usually encountered in open channel flow, $\sin \theta$ may be replaced with the channel slope $\left(S_{o}\right)$ and Eq. 5.1 reduces to

$$
\tau_{w}=\gamma R S_{o}
$$

where $R$ is the hydraulic radius $(R=A / P)$.

Turbulent flow occurs in most open channel flow problems, and the shear stress $\left(\tau_{w}\right)$ may be estimated as

$$
\tau_{w}=f \rho \frac{V^{2}}{8}
$$

where $f$ is a friction factor dependent on the surface roughness of the channel perimeter and the Reynolds number. Substituting Eq. 5.3 into Eq. 5.2 and solving for $V$ gives the Chezy equation

$$
V=C \sqrt{R S_{o}}
$$

where $C$ is the Chezy coefficient and is equal to $\sqrt{8 g / f}$. relation

Based on experimental data, Manning developed the following empirical

$$
C=\frac{R^{1 / 6}}{n}
$$

Figure 28: Derivation of Manning's Equation (Crowe, 2009) 


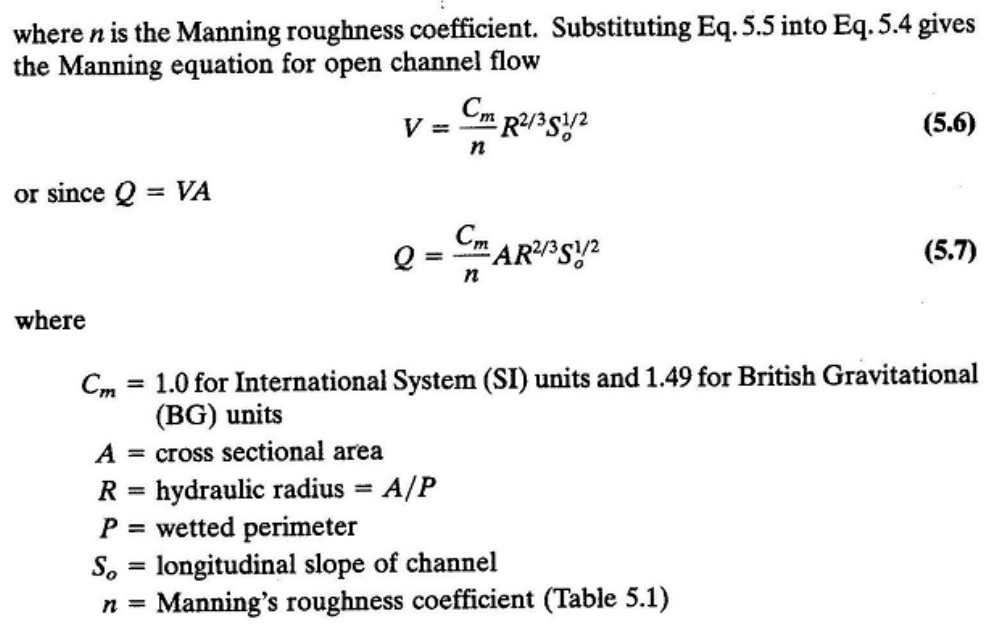

$$
V=\frac{C_{m}}{n} R^{2 / 3} S_{o}^{1 / 2}
$$

or since $Q=V A$

$$
Q=\frac{C_{m}}{n} A R^{2 / 3} S_{o}^{1 / 2}
$$

where

Figure 29: Derivation of Manning's Equation continued (Crowe, 2009)

Froude numbers were also calculated corresponding to the carrying capacity of each channel. A Froude number is a dimensionless parameter used to relate a flow's kinetic force to its gravitational forces. Froude numbers can be calculated by using the equation below:

$$
F r=\frac{\bar{V}}{\sqrt{g \cdot y_{n}}}
$$

In Equation 11, $\bar{V}$ represents the uniform flow velocity, $\mathrm{g}$ is gravity $\left(9.81 \mathrm{~m} / \mathrm{s}^{2}\right)$, and $\mathrm{y}_{\mathrm{n}}$ is the flow depth in the channel. This relationship also helps define if a flow is experiencing sub- or super critical flow. A value greater than one is associated with supercritical flow while values less than one are subcritical.

If flow changes from one state to another, a hydraulic jump will occur. A hydraulic jump that occurs as a result of supercritical flow becoming subcritical will cause a loss in kinetic energy. This phenomenon occurs if channel geometry, slope, or friction change dramatically and may actually be helpful in managing flow through a system. Specific energy, $\mathrm{E}_{\mathrm{s}}$, is the relationship between potential and kinetic energy of a flow. Equation 12 shows how to calculate $E_{s}$ for a given flow based upon its flow rate $Q$, flow depth $y_{n}$, gravity $\left(9.81 \mathrm{~m} / \mathrm{s}^{2}\right)$, and cross-sectional flow area.

$$
E_{s}=y_{n}+\frac{Q^{2}}{2 \cdot g \cdot A^{2}}
$$

For a known flow Q, two different flow depths can be associated with the same specific energy value. One flow depth corresponds to subcritical behavior, while the other represents supercritical behavior. The point at which there is a one-one relationship between flow depth and specific energy is known as the critical state. This is where the specific energy is a minimum for a given flow. Critical depth for a know flow rate can be calculated by using Equation 13 where $\mathrm{q}$ is the flow per unit width of the channel. A graph of flow depth vs. specific energy for varied flow rates can be seen in Figure 30. 


$$
y_{c}=\left(\frac{q^{2}}{g}\right)^{1 / 3}
$$

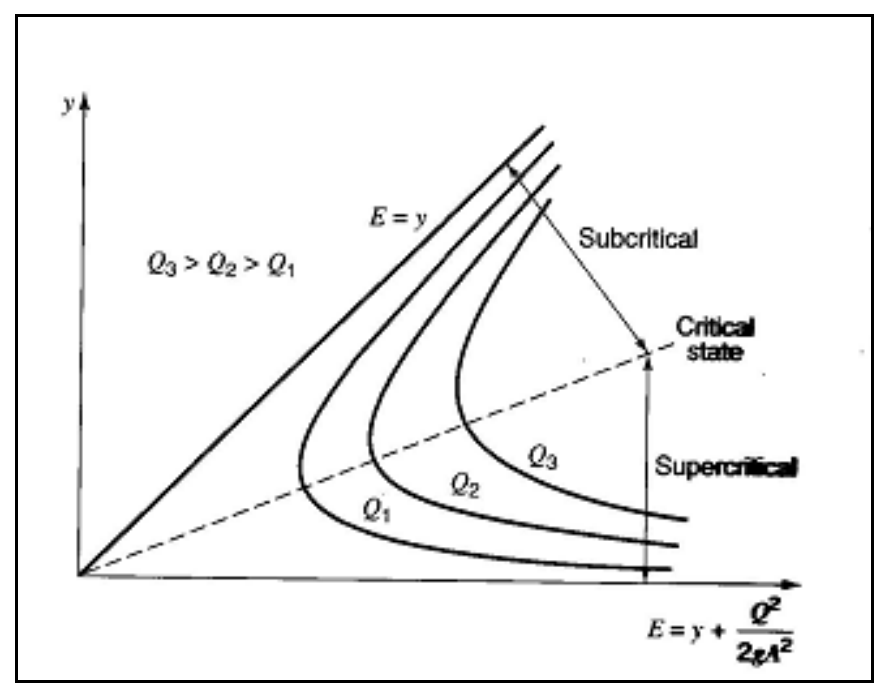

Figure 30: Flow depth vs. specific energy for varied flows (Mays, 2005)

A final property that was examined was the minimal velocity necessary for scouring to occur in the lined channels. In relation to Froude numbers, supercritical flows have a higher kinetic energy state than subcritical flows and thus scouring may become a greater concern. A study done by Fortier and Scobey (1926) for the American Society of Engineers looked at velocities permissible before scouring takes place in canals. The study dealt with canals that had flow depths of 0.91 meters or less. All channels of interest at the Ollantaytambo site meet this requirement. Ian Farrington later did a follow up study (Farrington, 1980) specific to irrigation canals in Peru. Farrington used the same table of scour velocities that Fortier et al developed and concluded that ancient farmers and engineers had an awareness of the principles of hydraulics (Farrington, 1980). Table 3 shows some of these values:

Table 3: Scour velocities for various materials

\begin{tabular}{|l|c|}
\hline Original material excavated for canal & $\begin{array}{c}\text { v (m/s) } \\
\text { - for water carrying } \\
\text { colloidal silts }\end{array}$ \\
\hline Fine sand (non-colloidal) & 0.76 \\
\hline Sandy loam (non-colloidal) & 0.76 \\
\hline Silt loam (non-colloidal) & 0.91 \\
\hline Alluvial silts when non-colloidal & 1.06 \\
\hline Ordinary firm loam & 1.06 \\
\hline Volcanic ash & 1.06 \\
\hline Fine gravel & 1.52 \\
\hline
\end{tabular}


Table 3 continued: Scour velocities for various materials

\begin{tabular}{|l|c|}
\hline \multicolumn{2}{|c|}{$\begin{array}{c}\mathbf{v}(\mathbf{m} / \mathbf{s}) \\
\text { Original material excavated for canal } \\
\text { colloidal silts }\end{array}$} \\
\hline Stiff clay (very colloidal) & 1.52 \\
\hline Graded, loam to cobbles, when non-colloidal & 1.52 \\
\hline Alluvial silts when colloidal & 1.52 \\
\hline Graded, silt to cobbles, when colloidal & 1.68 \\
\hline Coarse gravel (non-colloidal) & 1.83 \\
\hline Cobbles and shingles & 1.68 \\
\hline Shales and hard pans & 1.83 \\
\hline Hard rock & 4.06 \\
\hline
\end{tabular}

\section{Assumptions}

Specific assumptions had to be made about the design intent of elements in the fountain complexes and with the equations used to analyze flow properties. One of the first

assumptions made was to select a roughness coefficient of .03 to use for Manning's Equation. The selection was based upon comparing the rock lining of the channels to a chart of values in the textbook, Engineering Fluid Mechanics (Crowe, Elger, Williams, and Roberson, 2009). This chart is shown as Table 2. For the purpose of this study, a roughness coefficient between $0.20-0.35$ would have been acceptable. A value at either extreme would minimally vary the results the capacity analysis and thus have no effect on the resulting conclusions.

Also, a sensitivity analysis was used along with Equations 7 and 9 to calculate maximum capacities of various channels. Capacities were calculated for flow depth of 50 and $80 \%$ of a channel's total depth. This analysis allowed for a comparable study of reasonable channel flow. According to Wright, maximum capacities of Inca channels across Peru are consistent with this assumption. This assumption also allows for a factor of safety to account for splashing and to avoid overflow. Another assumption refers to the consistency of channel geometry. In order to apply Equations 7 and 9 it had to be assumed that all channels had consistent geometry throughout their length. This assumption applied primarily to sections that were sub grade.

Silts, clays, and fine sands were found to be the soil types present at the site. This determination was made by Eliot Wong and based upon observation in the field. In order to use Equation 6 the specific gravity of sediment is to be between $\mathbf{1 . 8 3}$ and 2.64 (Timmons et al, 1991). Sediment at this site tended to have a slightly higher value, between 2.67-2.7. The team assumed that this difference was negligible and that the equation developed by Timmons and Youngs can still be applied.

A final and critical assumption made was how to define optimal flow. The Inca designed fountains to operate with specific behaviors. At other Inca sites studied by Wright Water, it was evident that the purposes were as much ceremonial as they were practical. Since the fountains at Ollantaytambo were used for the worship of water the Inca designed them to create a specific effect on a viewer's senses (Protzen, 1993). Most of the fountains on site 
were designed for jet flow, and thus the team believes visual appearance was the bigger criteria. For all fountains (excluding the sequence of Fountains 1, 2, and 3) optimal flow is defined by the flow required to meet a specific jet displacement away from the fountain lip. After discussing with the head engineers and through analyzing the catch basins of the fountains it was decided the optimal drop displacement was mid-length of the basin. This displacement is also consistent with fountains at other Inca sites studied by WPI (Wright, 2006).

For Fountains 1, 2, and 3 optimal behavior is instead defined by qualitative measures. Instead of jet flow, these fountains were designed to have a sheeting flow behavior. The metric used for their optimal behavior was chosen to be the sound of water flowing through the sequence of fountains. Protzen describes such channels as "very important" and "conspciously located along major pathways or staircases" (Protzen, 1993).

There were two primary guidelines when running the optimal flow behavior tests, both based upon traditional behavior of Inca cascading fountains. First, the team wanted a flow large enough to create an audible noise and so that water didn't just trickle down the side of the fountains. Second, since the fountains are in sequence a flow rate that allowed all three fountains to simultaneously operate had to be established. Too large a flow rate would cause an uncontrolled flow in subsequent channels and the possibility that flow would jet out of a channel. Several field tests were run until field engineers decided these guidelines were met.

A final assumption made was that the jet of water coming out of a fountain experiences negligible friction or wind affects. In most instances water jetting from a fountain had little contact time with the air, enabling this assumption to hold. These assumptions allow for the simplification of gravity flow from which Equation 14 is derived.

\section{Test Procedures}

It was important to accurately map locations of channels, fountains, and other Inca structures as well as the correct flow paths of water throughout the system. The analysis and simulation model would not have been complete otherwise. Flow paths of canals where mapped using visual inspection for the above-ground canals and dye tracing for the underground canals. In the first control volume, all channels were above ground so visual inspection was used to map correct flow paths. Control volume I has two main canals, one that splits and then rejoins before combining with the second canal as the source to the Inkamisana.

The other four control volumes required dye to be used for the flow tracing. Since dye travels with the natural flow of water it showed the path the flow takes from the time it enters the bifurcation channel to the time that it leaves the fountain house and exists the complex. In the Upper Misana, dye helped confirm the location where Fountain 3 and Fountain 4 outputs joined. A different dye color was placed in each branch of the bifurcation and tracked until the combined color effect was seen.

There were several uncertainties about flow through the Lower Misana. Prior to testing, it was assumed that transverse flow (or flow moving laterally from one conduit to another via a 
channel) may occur somewhere along the three platforms. To test if this was so, dye was placed strategically in different parts of the conduits. Multiple colors were used and flow was tracked to see where a combined color effect might be seen. After running an extensive set of tests (nearly ten different combinations of dye injections), no evidence of transverse flow between conduits was found.

Dye was also used in this control volume to check for seepage. Even after earlier tests showed no transverse movement of flow in the conduits, small amounts of water could be seen coming out of $\mathrm{C} 1$ despite having closed off flow to it. To analyze this phenomenon, dye was added to the system upstream of the split of Channels C8 and C10 from Channel C7. Several tests were run, each time shutting flow to one of the split channels. The dye showed that some flow would leak into the closed channel beneath the dividing wall. Once the leakage was plugged with clay, the seepage ceased. Figure 33 shows this result:

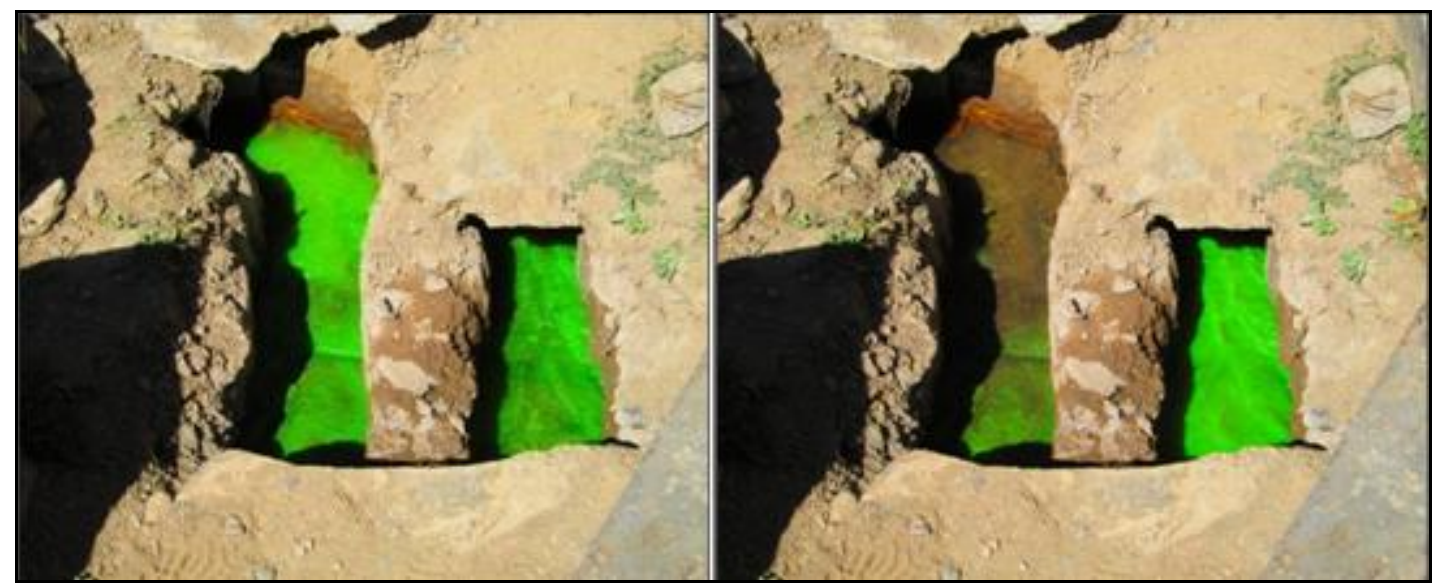

Figure 31: Seepage before and after sealing

The left side of the figure shows significant dye in both Channels $\mathrm{C} 8$ and $\mathrm{C} 10$, representing leakage through the channel wall. The right side of the figure shows negligible dye in the Channel 10. Locations of the channels, drops, and fountains were determined by measuring their size, orientation and location relative to benchmark objects nearby. The Huaca stone and Sacred Rock were both used as benchmarks during additional surveying.

As the research team traversed the site, sketches were drawn in both field books as well as on printed layout plans. These sketches were later used to edit the CAD drawings done of the site. All the maps and drawings were compiled at the end of the testing period and given to WPI to update plans in AutoCAD. WPI has a copy of all current plans of the entire site. Photographs were also taken of all elements of the hydraulic system. Channels, drops, fountains, and orifices were all documented. After each day's work, photos and field sketches were analyzed and discussed by a team of engineers and archaeologists. This process helped to determine what canals were Inca and which ones had been rebuilt.

During the field study of the sites specific tests were run in order to measure flow rates and velocities as well as flow paths and transit time in larger channels. Tests were differentiated 
based upon the section being analyzed and often had multiple trials run. Tracing dye and ping-pong balls as well as catch-flow and numerical methods were used to estimate these properties. The purpose of each of the 20 tests is listed below:

Test 1: Velocity and flow rate analysis in Channel H1 Test 2: Velocity and flow rate analysis in Channel $\mathrm{H} 2$ Test 3: Velocity and flow rate analysis in Channel $\mathrm{H} 3$ Test 4: Velocity and flow rate analysis in Channel C3 Test 5: Velocity and flow rate analysis in Channel C2 Test 6: Velocity and flow rate analysis in Channel C5 Test 7: Seepage test with dye tracing in Channel C7

Test 8: Velocity and transit time analysis for Conduit 1 (C10) Test 9: Velocity and transit time analysis for Conduit 2 (C11) Test 10: Velocity and transit time analysis for Conduit 3 (C12) Test 11: Velocity and flow rate analysis check in Channel $\mathrm{H} 2$ Test 12: Velocity and flow rate analysis check in Channel H3

Test 13: Flow rate analysis for Fountains $6 \mathrm{~A}$ and $6 \mathrm{~B}$

Test 14: Flow rate analysis for Fountains 7A and 7B

Test 15: Flow rate analysis at Drop D1

Test 16: Flow rate analysis at Drop D2

Test 17: Flow rate analysis for Upper Fountain

Test 18: Flow rate analysis for Princess Fountain

Test 19: Flow rate analysis for King's Bath

Test 20: Flow rate analysis for Rock Fountain

Tests 1-6, 11-12 and 15-16 were run with optimal flow directed to Fountains 1, 2, 3, and 4A. Tests 8-10, 13-14, and 17-20 were run with optimal flow to Fountains 6A/B, 7A/B or both. Results of all 20 tests can be found in Appendix 1. Optimal flow was earlier defined based upon jet displacement. The optimal jet displacement was approximately $1 / 2$ the length of a fountain's catch basin. In order to have an efficient methodology for these tests, a plan of approach was devised each day (and subsequently adapted based upon previous day's progress). Main priorities of each day are listed below:

Day 1: Verification of flow paths as well as channel \& fountain dimensions \& locations.

Day 2: Continued verification from day 1. Base flow measurements (tests 1-6).

Day 3: Continuation of tests 1-6. Additional surveying done by Huaca Rock and of Retention Basin.

Day 4: Seepage check of channels in Inkamisana Complex (test 7). Transit time analysis for Channels C10, C11, and C12 (tests 8-10).

Day 5: Check of base flow measurements (Tests 11-12, 15-16). Optimum flow analysis of Upper Misana

Day 6: Optimum flow analysis of Lower Misana (tests 13-14).

Day 7: Inspection of unfinished Fountains 4B, 4C, 5A, and 5B. 
Day 8: Optimum flow analysis of Manyaraki and Princess Fountain Complexes (tests 17-20).

Day 9: Compilation of all missing channel dimensions.

Specific equipment was also necessary to conduct these tests. Fluorescent dye tablets in three different colors were used for the dye tracing portion of the analysis. The tablets were ordered from Bright Dyes, a division of Kingscote Chemicals. The research team was careful to select non-toxic and biodegrading tablets in order to negate any toxic effects on the environment. Technical information for each dye used can be found in Figures $46-48$ in Appendix 2. Additional information can be found by visiting the website, www.brightdyes.com. Nearly 100 ping-pong balls were brought for flow measurements and tracing. The balls were green, blue, pink, orange and yellow. Buckets with known volumes were used for flow rate calculations at many of the fountains and a few other drop structures. The buckets had a line marked on their inside representing 18 liters. Stopwatches and 100 meter measuring tapes were used to mark and time flow through specific channel segments. Radios were supplied by WPI for all field engineers to coordinate tests and communicate across the large site.

Three different calculation techniques were used to calculate volumetric flows of canals and fountains: velocity-area, bucket test, and the Woodburn Equation. Tests 1-6 and 11-12 were conducted using both ping-pong ball and dye tracing methods. Channels for these tests were selected due to their direct correlation to the system's overall capacity. Both of these methods used the velocity-area technique.

First, the cross sectional area of the canals (channel width and flow depth) were measured at several points along each canal. Then velocity measurements were taken by measuring the time for a ping pong ball or a section of dye tracer to travel a measured distance along the canal. Next, each set of velocity and area measurements were averaged. Then the average area and velocity were multiplied to get the volumetric flow rate (Equation 8). Only dye was used when measuring the transit time and velocity in conduits 1,2 , and 3 (tests 8-10). The team attempted to use ping-pong balls, however, this method was stopped after multiple trials proved the balls were easily stuck in the channel.

All dye tracing tests were conducted by filling a bucket with water and adding 3 dye tablets. The three colors of dye used were, blue, orange, and yellow/green. However, after trial and error the yellow/green dye was used most because it was more easily visible due to its fluorescent characteristics. The dye tablets were then stirred into the water to ensure complete mixing. Each tablet is supposed to dye (the volumetric range in which the color is still visible) 60 gallons of water. The dyed water was then added into the canals where it would mix with the uncolored water flowing in the canal. The flowing dyed water was easily followed throughout the system and allowed for us to determine the speed of the water and flow paths of the canal.

The second technique used to determine volumetric flow rate was the catch-flow approach. This technique recorded the time elapsed to fill an 18 liter bucket with water. Tests 13-20 
were conducted using this approach. The bucket would be placed flush against the front face of a fountain or drop and held until water met the $18 \mathrm{~L}$ marking. For each fountain or drop analyzed, three sets of flow rate measurements were completed.

The third determination of flow was by using the Woodburn Equation and area of flow. This technique requires the flow depth, weir width, drop height and horizontal jet distance at the given fountain to be measured. Area of flow is calculated by multiplying the weir width by the flow depth. Next, velocity of the fountain jet is calculated based on the relationship of the distance of the splash point $\mathrm{X}$ from the fountain face and the distance $(\mathrm{H})$ the water drops before it reaches the basin. The "Woodburn Equation" (Equation 14) shown below, was used to determine this relationship:

$$
v_{w}=\frac{2.22 x}{\sqrt{H}}
$$

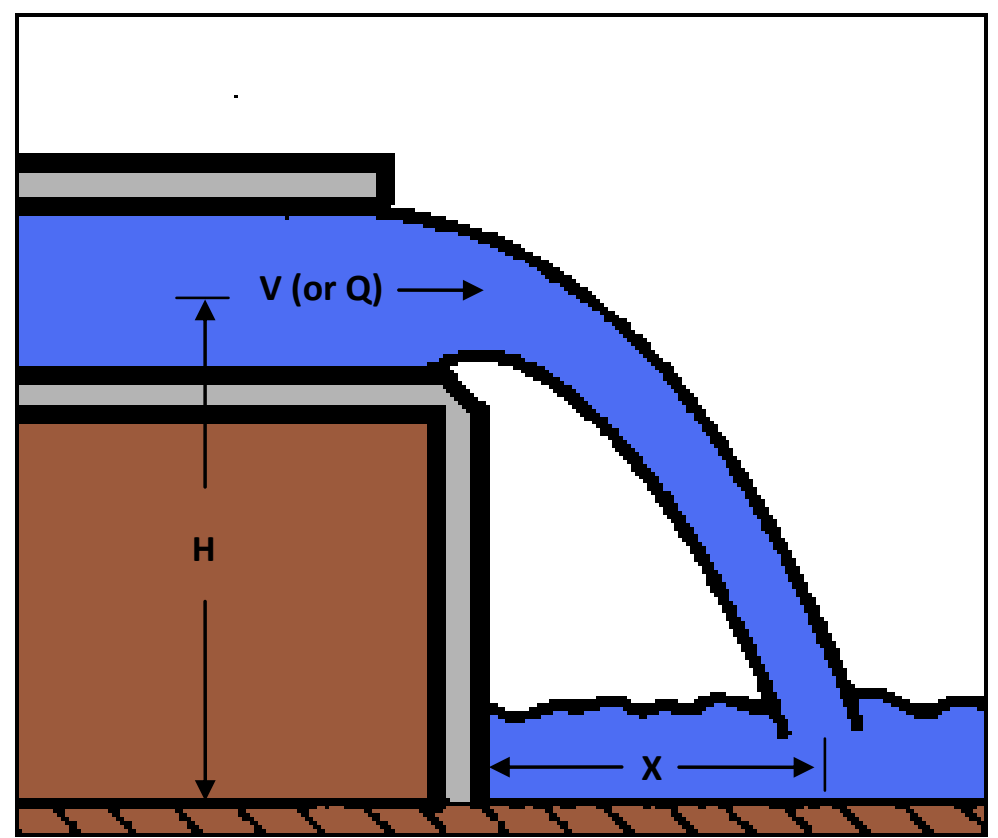

Figure 32: Visual of Woodburn Equation

The displacement was measured from the base of the fountain face to the center of the jet where it lands in the basin. Drop height was measured from the center of the flow depth to the basin floor. It was equal to the height of the fountain plus $1 / 2$ the flow depth. Volumetric flow rate is then calculated by multiplying the cross sectional area of the fountain/drop jet by the jet velocity in the $\mathrm{x}$ direction. The Woodburn method can also be used to back calculate for flow rate. If both drop height and drop displacement is know, the equation can be rearranged to calculate $\mathrm{v}$, and then to calculate Q. Derivation of the Woodburn Equation is shown: 
$y$ represent the coordinates of any other point in the jet. Neglecting air resistance, the horizontal component of the jet velocity is constant with the time $t$, from which

$$
x=V t
$$

The jet has a downward acceleration which conforms to the law of falling bodies, and therefore

$$
y=\frac{1}{2} g t^{2}
$$

Eliminating $t$ between the two equations

$$
x^{2}=\frac{2 V^{2}}{g} y
$$

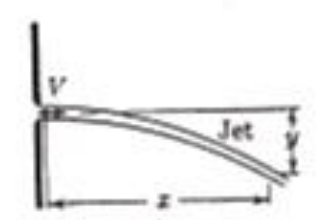

Fio. 60

which is the equation of a parabola with its vertex at the vena contracta. Solving for $V$,

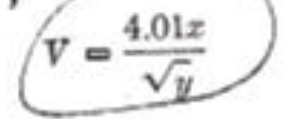

Figure 33: Derivation of Woodburn Equation (Crowe, 2009)

\section{Constraints}

There was a broad range of constraints that were encountered during the field testing. The first and most significant problem was maintaining the appropriate amount of water flow in the source canals. This was extremely difficult due to the variability of flow in the Huaca canal, up valley of the 8 terraces. The main cause of this variation was due to farmers upstream diverting the water for irrigation purposes. At one point, there was not enough water in the Huaca canal to feed any water into the Inkamisana. Even after adequate flow was sustained in the Huaca canal, flow levels had to be modified in order to achieve the required flow for optimal behavior at Fountains 1, 2, 3, and 4. This was a time consuming process that required adjusting a diverting stone at the diversion of the Huaca canal (the Inca valve was a stone placed in a channel to block flow). In some instances more water needed to be diverted, other times less. Both cases required estimation of downstream flow behavior of fountains and left room for inaccuracy.

After all necessary adjustments, it would still take time for the new flow pattern to move downstream and flow throughout the entire system to reach equilibrium. An engineer would be stationed at a specific fountain or drop to visually inspect the new flow behavior during all the adjustments. If flow levels still needed altered the entire process was repeated until finally desired fountain behavior was achieved. Another obstacle was not being able to run tests at certain times due to maintenance and rebuilding of channel sections. Some tests had to be run upstream prior to analyzing downstream channels. The inability to work on a channel caused delays in the subsequent tests and planned analyses. Clogged channels were also a problem despite sediment transport occurring due to flow. Channels were often left exposed to 
tourists and as a result dirt was often kicked into channels in large clumps. Channel walls may have also partially collapsed into the channels. This build up affected the true capacities of channels and even prevented us from completing ping-pong ball tests. A makeshift snake was used in order to clean out Conduit 3 prior to conducting a series of transit time tests. Previously C 3 could only carry a small flow due to sediment build up near the inlet of source 2.

Errors in flow rate measurements vary by source. Certain tests resulted in conflicting results and thus a check test had to be completed to find the source of error. After reviewing the results of Tests 2 and 3 it was clear that the estimation of flow rate was much too high. To check these flows Tests 11-12 and 15-16 were run. Results showed a more reasonable flow rate and it was concluded that the source of error was variation of flow upstream. Flow rates changed even as tests were being conducting, thus cross sectional data did not correspond to velocity measurements collected.

The technique that required cross sectional area and velocity of a canal to be measured had the most potential for error. Error in this technique is a result of inaccurate or nonrepresentative velocity measurements. Flow in several channels tended to have wave-like flow behavior. This behavior may have been caused by wind or may have been due to inability to reach an equilibrium flow. These oscillations in flow depth may have led to measurement error and thus compounded flow rate calculation error. In some instances, wind affected the movement ping pong balls as they flowed downstream. Wind usually increased the travel time of the balls and thus velocity of flow appeared slower as wind tended to resist the direction of flow.

There were timing errors in several of the tests. Since the dye plume dispersed as flow paths lengthened, measuring the travel time required the movement of the center of the plume to be tracked. Fluorometers were not used in the field and so tracing was done by eye, thus causing potential error. Variability in channel cross-sectional area was also a source of error (most channels had fairly uniform geometries).

Many of these errors were minimized by conducting multiple trials, using both dye and ping pong balls for each measurement. Measurements of the cross-sectional area were taken at the beginning middle and end of each canal to further reduce error (for longer channels up to 5 sets of measurements were taken). The error in the catch-flow method is mainly a result of inaccurate volume readings. During some of the tests, water would splash and not be captured by the bucket. Estimating when the bucket reached the exact $18 \mathrm{~L}$ marking also added error. Multiple tests were run and flawed trials were scrapped in order to minimize error.

The Woodburn analysis relies on the assumption that there is no air resistance or wind to affect the horizontal velocity of the water. This assumption leads to a slightly higher estimate of flow from a fountain/drop. However, since drop heights are relatively small and contact time with the air is fairly short, these errors are negligible. 
Constraints and sources of error in field measurements did not prevent reasonable results to be collected. The effect of the constraints was additional time required to run each test. The Woodburn and bucket techniques yielded similar flow estimations and were considered reasonable results.

\section{Simulation Model}

\section{Design}

The simulation model was designed to model the flow behavior throughout four of the five control volumes of the Inkamisana Complex (The Upper Misana, Lower Misana, Fountain House Complex, and Princess Fountain Complex). The Upper Misana includes Fountains 1 through 4 (Fountain 4 being the conglomerate of 4A, 4B \& 4C) as well as two of the source inputs (Huaca Canal and Manyaraki Canal 1) locations. The Lower Misana is comprised of Fountains 5A/B, 6A/B, and 7A/B. The King's Fountain and Rock Fountain (RA, RB \& RC) make up the Fountain House Complex.

The fourth control volume is independent of the other three and includes the Princess Fountain and Upper Fountain as well as the Manyaraki Canal 2 source. The first three control volumes are intimately related as initial inputs are carried throughout their connected system.

An important aspect of the simulation model is its ability to incorporate user varied inputs to model changing field conditions at the site (varied inputs also help the user to create desired flow behavior at specific elements). Another unique product is the image based map of the varying channel and fountain behavior. This is necessary in order to relate the behavior of the system at a micro level (i.e. at an individual fountain or channel) to how it behaved as an entire system.

The layout of the model was constructed in such a way as to differentiate the behavior of each distinct control volume as well as show individual channel and fountain behavior throughout the system. Within the simulation interface, the flow analysis is first differentiated vertically in correlation to each control volume. Then these control volumes are delineated laterally into discrete fountain systems to be analyzed: 


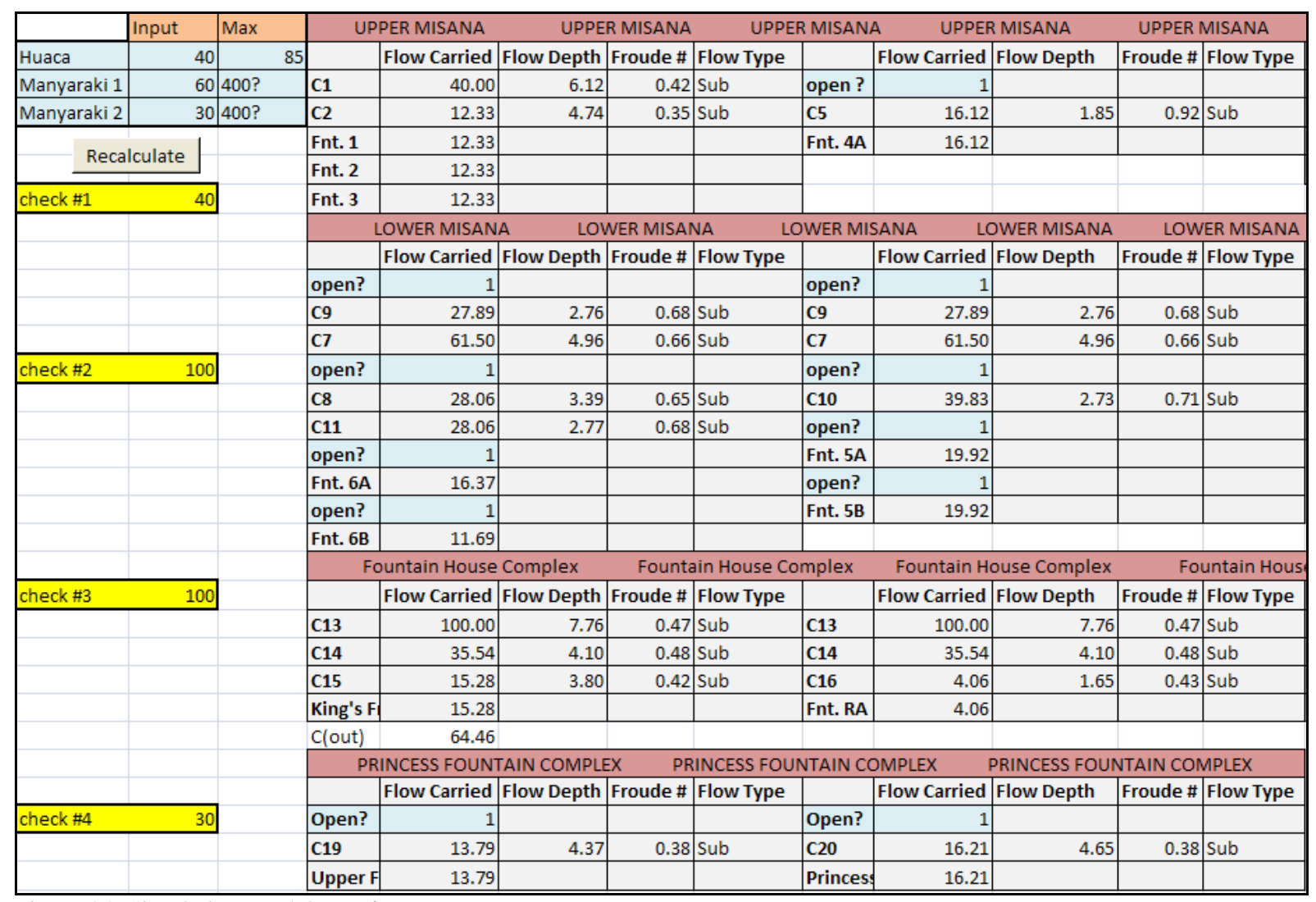

Figure 34: Simulation Model Interface

The interface also includes two tables of the flow parameters calculated through the simulation. One table displays the behavior and the other displays fountain behavior. In addition, the final three tabs in the excel project join map layouts with the various outputs of the simulation to create a comprehensive representation of the flow network.

\section{Assumptions}

The simulation model relies heavily on several flow assumptions. First, since only fountain behavior was being modeled the control volume at the far north end of the site was not included. This control volume was instead treated as a discrete point source. In addition, when calculating the amount of flow to be diverted at the junction of multiple channels, a simple ratio of capacities was used as the criteria. This ratio was determined based upon the relationship of each channel's maximum flow capacity to total available flow at the junction:

$$
Q_{\text {out } 1}=Q_{\text {cap } 1} /\left[Q_{\text {cap } 1}+Q_{\text {cap } 2}+\ldots Q_{\text {cap } n}\right]^{\cdot Q_{\text {in }}}
$$

For example if Channel A was split into Channels B and $\mathrm{C}$, then the flow to Channel $\mathrm{B}$ was calculated as $\mathrm{Q}_{\mathrm{MAX}, \mathrm{B}} /\left(\mathrm{Q}_{\mathrm{MAX}, \mathrm{B}}+\mathrm{Q}_{\mathrm{MAX}, \mathrm{C}}\right)^{*} \mathrm{Q}_{\mathrm{A}}$. This relationship assumes that feed channels which split into parallel channels have the same angle of approach. In reality, the intersection of a split channel and a feed channel can be as sharp as a perpendicular angle. Flow 
distribution at such a junction would vary significantly from how it would be modeled in the simulation. The bottoms of channels connecting at a junction are also assumed to be at the same level. This simplifies the calculation of flow distribution to each channel. At several locations in the Inkamisana this assumption is not true. However, detailed surveys of these junctions have to be completed in order to adjust this assumption.

The governing equation used to estimate optimal channel flow rates was the Woodburn Equation. This equation is the most accurate of the three flow measurement techniques. In the simulation model, the Woodburn Equation was used to calculate flow rate $\mathrm{Q}$ for a specified drop distance in the $\mathrm{X}$-direction. This distance was usually taken as one-half the width of the splash basin. Also, to accurately model the flow rates for the Princess Fountain and Upper Fountain, the flow depth in the fountain jet was estimated to be roughly $1 / 3$ the depth of flow in the source channel. With this assumption, simulated fountain flow rates were close to resembling those measured in the field.

\section{Simulation Code in Microsoft Excel}

There are a few important components of the coding required to make the simulation run a reasonable analysis of the site. First, an understanding and usage of nested functions (e.g. an if-then statement) was a basis for relating flow bifurcation and distribution throughout the system. A 'IF' statement requires a specific scenario to occur in order for a defined output to be generated in the target cell. Within an 'IF' statement, an 'AND' statement can also be inserted (multiple scenarios ALL have to be true in order for this output to be generated) or an 'OR' statement (at least one of the predefined scenarios have to be true in order for this output to be generated). An example of an 'IF', 'AND', and 'OR' statement is shown below:

\section{EX 1: IF (A12=1, 'OPEN') \\ EX 2: $\operatorname{IF}\left(\mathrm{AND}\left(\mathrm{A} 12=0, \mathrm{~A} 14=0,{ }^{\prime} \mathrm{CLOSED}\right)\right)$ \\ EX 3: IF (OR (A12=1, A14=1, 'OPEN'))}

The function in the first example will return the word 'OPEN' to the target cell only if cell $\mathrm{A} 12=1$. In the second example the word 'CLOSED' will be generated if BOTH A12=1 and A14=1. In the final example the word 'OPEN' will appear in the target cell if EITHER $\mathrm{A} 12=1$ or $\mathrm{A} 14=1$. There are a broad number of conditional statements that can be created using these three nested functions.

Another important component of the code is the solver program in Excel. This application allows for an equation to solve a non-separable equation (e.g. Equations 7 and 9 which can be used in solving for flow depth). It does this through an iterative approach that forces a target cell to zero while changing a designated input cell. The target cell is where the equation to be solved is stored. Constraints can be added to the application, such as upper and lower limits to the range of solutions. Finally, the use of an Excel Macro is a powerful tool for allowing user interaction and incorporating varying inputs to the model. A Macro is a set of instructions that are defined and then can be triggered through a button or keyboard shortcut 
within the spreadsheet. Excel uses Visual Basic (VBA) to write and store Macros before they are applied to a spreadsheet. This tool is a powerful way to eliminate the need to repeat the steps of common tasks over and over.

Several obstacles had to be overcome when using these features to write the codes in the model. First, Excel allows a maximum of 7 nested functions per cell. However, numerous channel relationships in the model required up to 16 of these statements. To get around this, the cell equations had to be written in such a way as to combine as many 'like' terms (scenarios that yielded similar results) so as to meet this maximum allowance. Another limitation of using Excel is the scope of its predefined "Solver" application. In order to run properly the function is coded to run its iterative process based upon non-varying inputs. The limitation of this approach, however, is that if earlier inputs to the system are changed, the function does not automatically re-solve the equation. In order to adapt this feature to the design intent of the simulation, a Macro had to be constructed which when applied would run through the desired re-solving process.

Data collected in the field about channel and fountain geometry as well as correct flow paths was used to reasonably design the model. Statistics about optimal behavior of the fountains in the field was used to relate simulated fountain behavior. This information is stored in several tables within the model interface. User inputs to the model include the three initial flow sources as well as valve behavior for 15 distinct elements. Knowledge of maximum capacity at these channels is not necessary, as these values are already contained in the cells adjacent to the flow input cells. Initial flows are to be in gallons per minute. The valves are located at Channels C4, C5, C6, C8, C9, C10, and C12 and Fountains 6A, 6B, 7A, 7B as well as the Upper and Princess Fountains. Valves were also placed to allow simulation of flow to the unfinished Fountains 5A and 5B. These valves relate whether flow is allowed to be carried through the corresponding element. If a valve is to be set open, the number 1 is to be entered and if it is to be set shut, the number 0 . After all inputs are entered or adjusted the user also must click the Recalculate button (located directly beneath the flow input cells) to run through the analysis.

In the model, nested functions were first applied to analyze how flow to a junction was distributed to each joined channel. This process was carried throughout the entire system until flow through each channel and then to each fountain was known. Next, the Solver application was used to solve for the flow depth in each channel based upon these flow rates. By applying Equation 9 the model can solve for flow depth (all variables are now defined except for $\mathrm{R}_{\mathrm{H}}$ which is directly related to $\mathrm{y}_{\mathrm{n}}$ ). After this step, the Excel Macro described previously was applied to re-solve for the depths if inputs are changed. Flow depth at each fountain was a composite of information about the feed channel and whether flow is split to an adjacent fountain (e.g. with Fountains 7A and 7B). An algorithm was used if flow was to be split at the junction of multiple canals. The algorithm was similar to what was used in deciding flow distribution except with respect to each fountain's optimal flow requirement.

Other flow channel and fountain parameters are also calculated based upon these results. Channel parameters include the Froude number and associated flow condition (subcritical, 
critical, or supercritical), flow velocity, and whether the flow can be considered self-cleaning. Froude numbers were calculated by using the flow depth and velocity calculated through the simulation of flow through the system. The Froude number then corresponds to a flow condition. If Fr is greater than 1, the flow is classified as supercritical. If it is less than 1, it is classified as subcritical. Flow with a Fr number of 1 is considered critical (i.e. on the verge of being either sub- or super-critical). To calculate flow velocity, Equations 7 and 8 can be applied or the flow rate can be divided by the cross-sectional area of flow. The crosssectional area is directly related to the flow depth calculated in previous steps of the simulation $\left(A_{x}=y_{n} x b\right.$, where $b$ is channel width). Once the velocity in each channel is computed it is compared to the velocity required for a channel to be considered self-cleaning.

$\mathrm{V}_{\text {clean }}$ is calculated using Equation 6 and is based upon the previous soil characterization of B. A table then compiles the values for min, mid, and max particle sizes for each soil type within class C. If a channel's flow velocity is greater than or equal to the maximum velocity in the table it is considered self-cleaning. Otherwise the channel is not self-cleaning.

Additional fountain parameters include jet distance in the $\mathrm{x}$-direction and whether the fountain is behaving ideally. Equation 9 can be rearranged and used to calculate the horizontal 'jet distance' with respect to the x-direction. The flow rate, $\mathrm{Q}$, coming out of the jet is an output of earlier calculations and can be used to solve for this distance, $x$. Lastly, in order to determine whether a fountain behaved ideally, the model was programmed to compare the jet behavior of the simulated fountains to the observed jet behavior of each fountain during the field tests. A range of $\pm 20 \%$ of the field $x$ values was allowed to be considered ideal. If a fountain had flow outside of this range it was considered non-optimal behavior. Nested functions were used to decide flow classification, self-cleaning properties, and optimal behavior.

\section{Output}

The simulation models yields both qualitative and quantitative outputs. The flow parameters calculated and then tabulated in the model are depth of flow, flow rate carried, Froude number, velocity of flow, and jet distance in the x-direction. These values are collected for each fountain, drop or channel and compiled into two separate tables in the program. One table includes these first four flow parameters for each channel in the system as well as each channel's geometry. The other table includes the jet behavior specific to each fountain as well as each fountain's geometry.

Qualitative outputs include three hydraulic maps with specific flow parameters tied to them. The three maps are "Flow to Fountain vs. Optimal Behavior", "Channel Flow Rate vs. Flow Characterization" and "Channel Velocity vs. Self-Cleaning Capability".

In the first map, each fountain has two cells coupled to it, a value cell and a descriptor cell. Value cells contain the flow rates calculated and stored in the fountain properties table in the simulation tab. Descriptor cells are located in the cell adjacent to the value cell. These cells contain a text that distinguishes whether the flow does or does not meet optimal fountain behavior requirements. A "YES" is applied to the cell for any flow within the predetermined 
accepted range to be considered optimal. A "NO" is applied to any value outside of this range, except for a value of zero. If a fountain receives zero flow, then the text "NO FLOW" will appear in the value cell instead and the descriptor cell will become empty. An image of this map is shown in Figure 37.

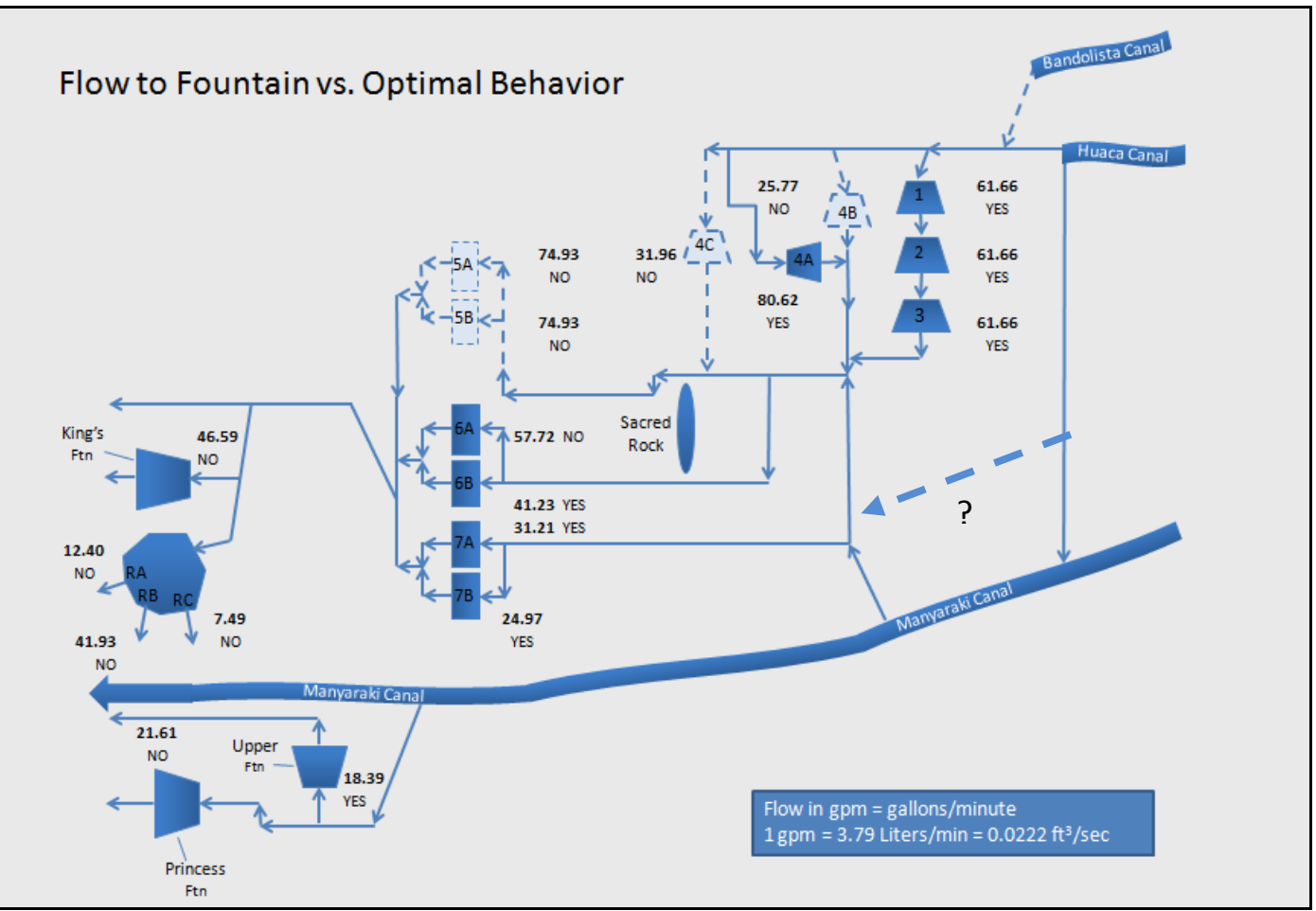

Figure 35: Map of flow rate vs. optimal behavior

In the second map, each channel also has both a value cell and descriptor cell tied to it. This map relies upon the outputs of the channel properties table in the simulation tab. The value cell contains the flow rate running through the specific channel. Its descriptor cell distinguishes whether the channel has critical, sub- or super-critical flow. The word "SUB" is applied to the cell if the channel's Froude number is less than 1. The word "SUPER" is applied to a channel whose Froude number is greater than 1. For any channel with a Froude number equal to 1 , the word "CRITICAL" is applied. Figure 38 shows an example output of this map. 


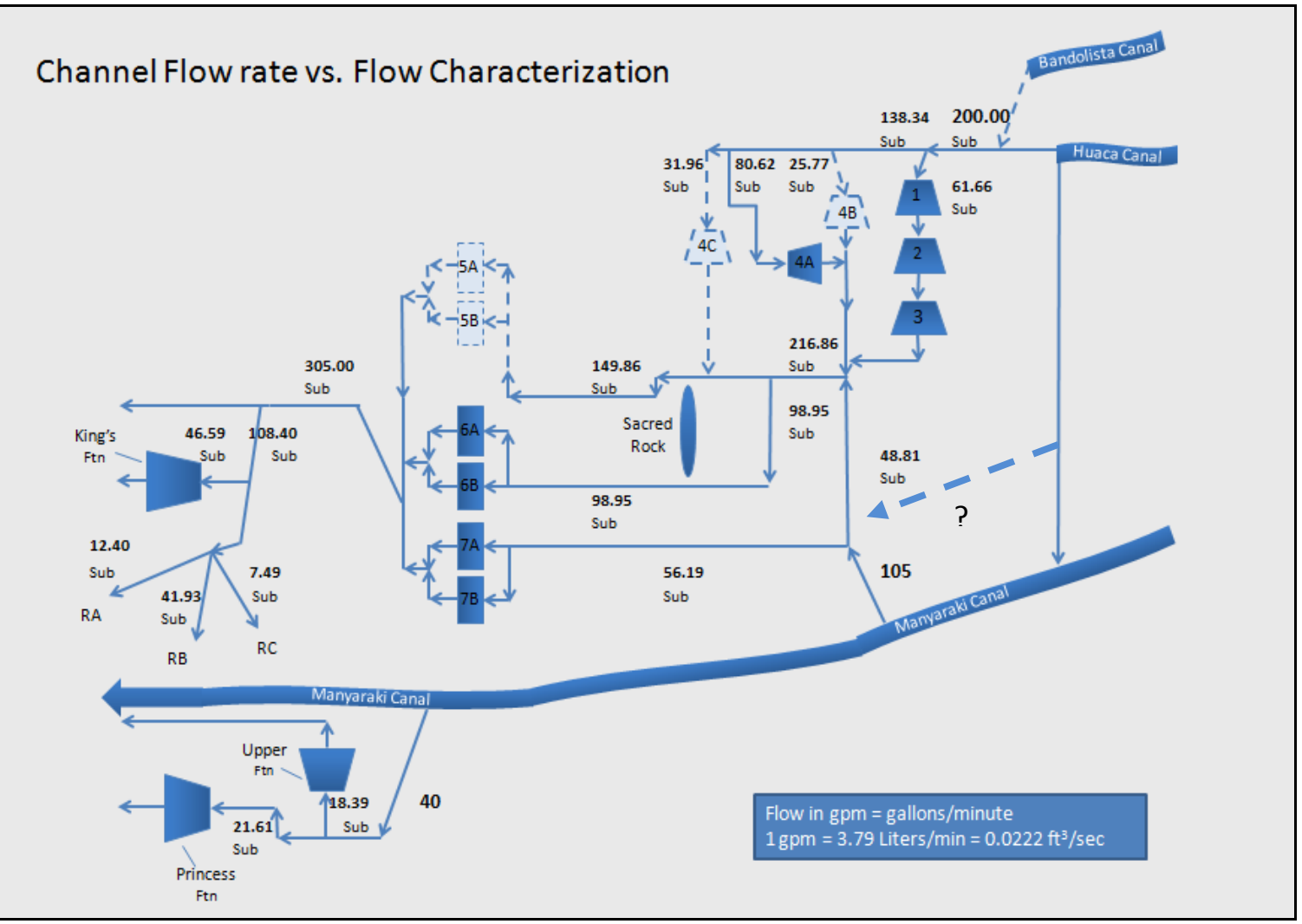

Figure 36: Map of flow rates vs. flow characterization

In the final map, each channel has a value and descriptor cell applied to it, both different parameters than the previous map. The value cell in this map contains the velocity of flow through each channel. Self-cleaning capability is stored in the descriptor cell. If the velocity of flow through a channel is greater than or equal to the flow required to clean the channel, the word "YES" is applied to this cell. If not, the word "NO" is applied. The parameters placed on this map are contained in the channel properties table in the simulation tab. Figure 39 shows a sample version of this map. 


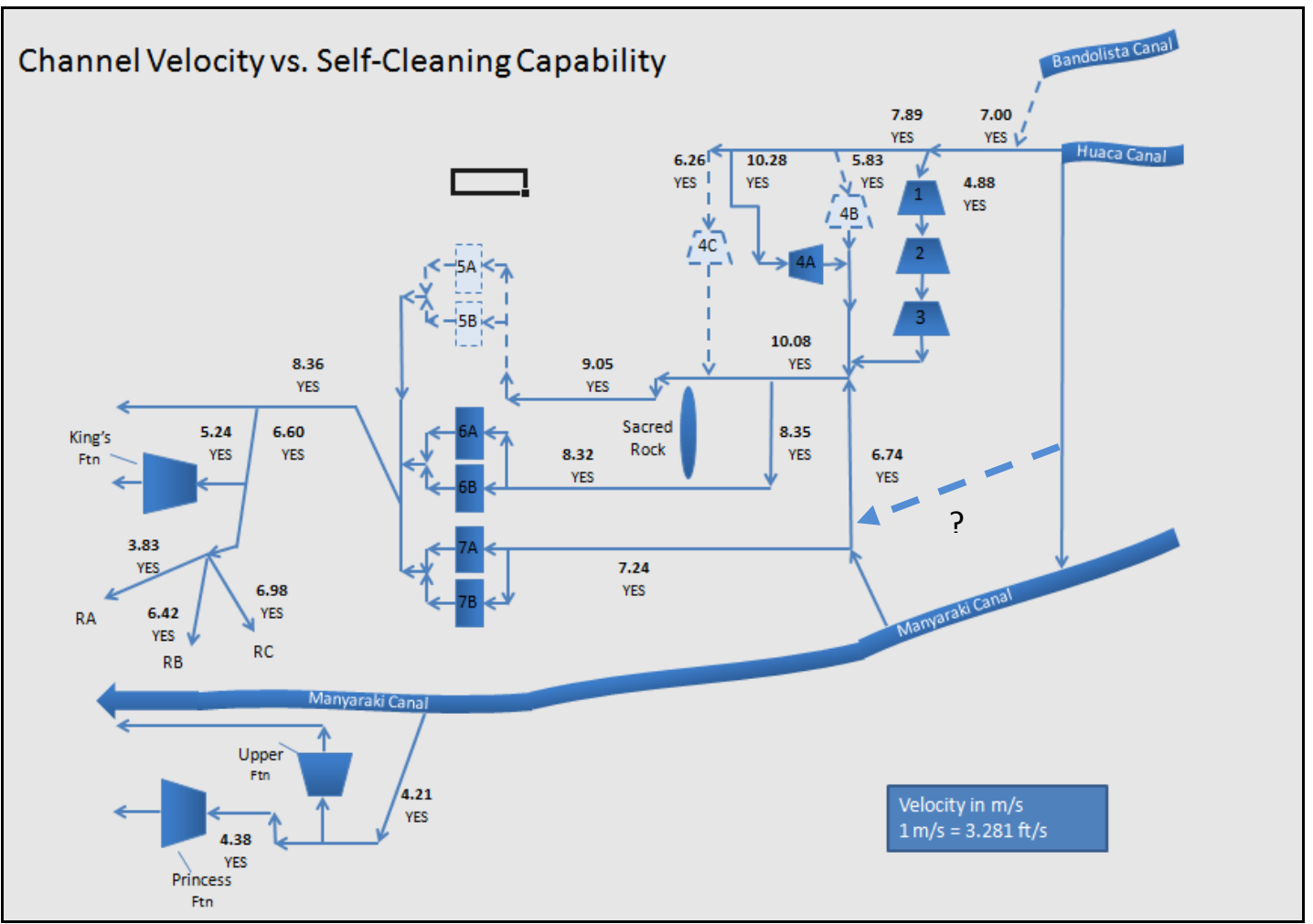

Figure 37: Map of channel velocity vs. self-cleaning capability

\section{Results}

Over the nine day data collection period, 60 individual tests were run. Each of the broader test types subsequently had several tests run to analyze flow behavior throughout the complex. These tests resulted in a detailed data analysis of flow through each control volume. Both quantitative and qualitative conclusions can be drawn from this analysis. Results of all tests have been compiled into comprehensive tables. All data not shown in this section can be found in the appendix. Detailed sketches of cross sections can either be found in the appendix or in the supplementary sources indexed. Numerous maps were also created to show the location of hydraulic elements relevant to specific sections of the site. The main map shows a comprehensive layout of the site and includes all four control volumes. Another map, Figure 25, labels the location of each channel within the lower four control volumes. All maps include channels, fountains, and drops as well as terraces and other landmarks located at the site.

The field measurements provided essential information of the site. In some cases additional hydraulic elements were discovered, while other times dimensions and locations were modified to correctly match field conditions. During an analysis of the area surrounding Fountain 4A it was determined that possibly two more side fountains were intended to be completed. A channel carved to the left of $4 \mathrm{~A}$ was traced and an apparent outlet orifice was found leading into Channel C7. A channel carved to the right of 4A seemed to dead-end. However, further study showed a possible catch basin and flow path for an additional fountain. After discussion of both unfinished elements, these new findings were deemed 
Fountains 4B and 4C respectively. The addition of these two Fountains to the Upper Misana directly affects the flow distribution patterns through the system. An orifice that emptied into Channel C7 was also discovered. This finding further supported the existence of the unfinished Fountain 4C

At the lower end of the Inkamisana Complex, unfinished Fountain 5 was studied in more detail. The surveying team the previous year found a partially carved rock face similar to that at Fountains 6 and 7. With further inspection it was noted that two spouts for fountains had been left unfinished. After being compared to the rest of the Lower Misana, it was concluded that the set of Fountains5A and 5B was to mirror both the 6 and 7 double fountains. It concluded that these fountains were intended to be fed by Conduit 1 . This conclusion was based upon the fact that Conduit 1 does not feed any other fountain and is located at an elevation and proximity that could adequately supply water to 5A and 5B. Comparing capacity of Conduit 1 to the optimal flow requirements for both of these fountains further supported this conclusion.

There were also several drops that had not been located on the layout maps as well as inaccurate location of walls in several places. Sketches of the drop orifices were tied to the known location of several terrace walls. Additional surveying was done to pinpoint the true dimension and location of inaccurately drawn walls. At the north end of the Inkamisana, the location of the Huaca relative to the Huaca canal and Manyaraki Canal had to be corrected. During cleaning of Channels C7 and C10, a high status green rock was discovered lining the channel bottoms. This rock was similar to rock found by WPI at other Inca ruins including Machu Picchu. Green rock gives credence to the spiritual significance of the Inkamisana, especially in the section near the Fountain 4 complex.

The research team was able to conclude several important aspects of the flow paths throughout the complex. One question initially was whether there was transverse flow between Conduits 1,2, and 3. Through a series of dye trace experiments the team was able to conclude that each conduit was a distinct channel. This means that Conduit 3 solely feeds Fountains 7A and 7B, Conduit 2 feeds Fountains 6A and 6B, and Conduit 1 feeds the existing drop on the side of Fountain 6B. This drop potentially could have fed the unfinished Fountains 5A and 5B.

To test this finding, trials were run in which flow was withheld to one of the conduits (multiple tests were run with a different conduit closed each time). Surprisingly small amounts of flow appeared downstream in conduits that had been closed. This finding led to the realization that seepage must be occurring in segments of the underground channels. In particular, that leakage occurred in Channel 7 just before it splits into Channels C8 and C10 near the Sacred Rock. To eliminate this leakage, packed clay was added to plug some cracks and holes in the channel walls. Once seepage effects were eliminated, no evidence of transverse flow distribution between the conduits occurred. As a result of this finding, the hydraulic simulation of the Lower Misana was greatly simplified. 


\section{Data}

Geometry of channels throughout the site was compiled into Table 1.

Table 4: Channel Geometries

\begin{tabular}{|c|c|c|c|c|c|}
\hline Channel & $\mathbf{s}$ & $\mathbf{w}(\mathbf{c m})$ & d (cm) & $\mathbf{n}$ & $\begin{array}{c}\mathbf{R}_{\mathbf{h}} \\
(\mathbf{c m})\end{array}$ \\
\hline H1 & 0.001 & 65.33 & 35.67 & 0.05 & 17.05 \\
\hline H2 & 0.01 & 23 & 9.67 & 0.03 & 5.25 \\
\hline H3 & 0.0218 & 24 & 10 & 0.03 & 5.45 \\
\hline C1 & 0.01 & 12.7 & 13.3 & 0.03 & 4.30 \\
\hline $\mathrm{C} 2$ & 0.01 & 6.83 & 8 & 0.03 & 2.39 \\
\hline $\mathrm{C3}$ & 0.02 & 8.5 & 9 & 0.03 & 2.89 \\
\hline C4 & 0.02 & 13 & 7 & 0.03 & 3.37 \\
\hline C5 & 0.04 & 14 & 12 & 0.03 & 4.42 \\
\hline C6 & 0.02 & 12 & 9 & 0.03 & 3.60 \\
\hline C7 & 0.02 & 17 & 14 & 0.03 & 5.29 \\
\hline C8 & 0.02 & 14 & 22 & 0.03 & 5.31 \\
\hline C9 & 0.02 & 18 & 12 & 0.03 & 5.14 \\
\hline C10 & 0.02 & 25 & 13 & 0.03 & 6.37 \\
\hline C11 & 0.02 & 18 & 25 & 0.03 & 6.62 \\
\hline $\mathrm{C12}$ & 0.02 & 14 & 18 & 0.03 & 5.04 \\
\hline $\mathrm{C} 13$ & 0.01 & 20 & 23 & 0.03 & 6.97 \\
\hline C14 & 0.01 & 18 & 16 & 0.03 & 5.76 \\
\hline C15 & 0.01 & 10 & 10 & 0.03 & 3.33 \\
\hline C16 & 0.01 & 9 & 4 & 0.03 & 2.12 \\
\hline C17 & 0.02 & 18 & 4 & 0.03 & 2.77 \\
\hline C18 & 0.07 & 4 & 3 & 0.03 & 1.20 \\
\hline C19 & 0.01 & 8 & 8 & 0.03 & 2.67 \\
\hline C20 & 0.01 & 8.5 & 8.5 & 0.03 & 2.83 \\
\hline
\end{tabular}

Using Equations 7 and 9, both flow and velocity capacities of channels were calculated. Geometry data compiled earlier was used in these equations. Froude numbers were then computed for the resulting velocities in each channel. Table 2 shows the Froude numbers and capacities at 50 and $80 \%$ flow depth in each channel: 
Table 5: Channel capacity and corresponding Froude value

\begin{tabular}{|c|c|c|c|c|c|c|}
\hline Channel & $\begin{array}{c}Q(\text { (@ .8d) } \\
(\mathrm{gpm})\end{array}$ & $\begin{array}{c}\mathbf{V}(@ .8 d) \\
(\mathbf{m} / \mathbf{s})\end{array}$ & Froud \# & $\begin{array}{c}\text { Q (@ .5d) } \\
\text { (gpm) }\end{array}$ & $\begin{array}{c}\mathbf{V}(@ .5 d) \\
(\mathbf{m} / \mathbf{s})\end{array}$ & Froude \# \\
\hline H1 & 533 & 0.18 & 0.11 & 277 & 0.15 & 0.11 \\
\hline H2 & 121 & 0.43 & 0.49 & 61.7 & 0.35 & 0.51 \\
\hline H3 & 198 & 0.65 & 0.73 & 101 & 0.53 & 0.76 \\
\hline C1 & 83.2 & 0.39 & 0.38 & 45.4 & 0.34 & 0.42 \\
\hline $\mathrm{C} 2$ & 18.3 & 0.26 & 0.33 & 10.1 & 0.23 & 0.37 \\
\hline $\mathrm{C} 3$ & 40.9 & 0.42 & 0.50 & 22.3 & 0.37 & 0.55 \\
\hline C4 & 52.6 & 0.46 & 0.62 & 27.3 & 0.38 & 0.65 \\
\hline C5 & 167 & 0.79 & 0.81 & 90.1 & 0.68 & 0.88 \\
\hline C6 & 66.1 & 0.48 & 0.57 & 35.2 & 0.41 & 0.62 \\
\hline C7 & 189 & 0.63 & 0.60 & 101 & 0.54 & 0.65 \\
\hline C8 & 250 & 0.64 & 0.49 & 141 & 0.58 & 0.56 \\
\hline C9 & 167 & 0.61 & 0.63 & 88.0 & 0.51 & 0.67 \\
\hline C10 & 287 & 0.70 & 0.69 & 148 & 0.58 & 0.72 \\
\hline C11 & 422 & 0.74 & 0.53 & 235 & 0.66 & 0.60 \\
\hline $\mathrm{C12}$ & 196 & 0.61 & 0.52 & 109 & 0.55 & 0.58 \\
\hline C13 & 314 & 0.54 & 0.40 & 173 & 0.47 & 0.45 \\
\hline C14 & 171 & 0.47 & 0.42 & 92.5 & 0.41 & 0.46 \\
\hline C15 & 41.5 & 0.33 & 0.37 & 22.6 & 0.28 & 0.41 \\
\hline C16 & 10.7 & 0.23 & 0.42 & 5.48 & 0.19 & 0.43 \\
\hline C17 & 35.4 & 0.39 & 0.69 & 17.3 & 0.30 & 0.69 \\
\hline C18 & 6.60 & 0.43 & 0.89 & 3.51 & 0.37 & 0.96 \\
\hline C19 & 22.9 & 0.28 & 0.36 & 12.5 & 0.25 & 0.39 \\
\hline $\mathrm{C20}$ & 26.9 & 0.29 & 0.36 & 14.6 & 0.26 & 0.40 \\
\hline
\end{tabular}

After all data was collected during optimal flow rate tests, the required flow rate at each of the fountains was calculated. Depending on the fountain only a few of the flow techniques could be applied. For instance, since Fountains 4B, 4C, 5A, and 5B are currently unfinished, the only metric for estimating optimal flow was the Woodburn method. At Fountain 4A, all three techniques could be used. Table 3 summarizes these findings: 
Table 6: Fountain Optimum Flow Requirements as per each method (gpm)

\begin{tabular}{|r|r|c|c|c|}
\hline Fountain & $\mathbf{Q}_{\text {woodburn }}$ & $\mathbf{Q}_{\text {bucket }}$ & $\mathbf{Q}_{\text {dye }}$ & $\mathbf{Q}_{\text {ball }}$ \\
\hline $\mathbf{1}$ & N/A & N/A & 10.9 & 8.99 \\
\hline $\mathbf{2}$ & N/A & N/A & 10.9 & 8.99 \\
\hline $\mathbf{3}$ & N/A & N/A & 10.9 & 8.99 \\
\hline 4A & 28.3 & 26.9 & 45.3 & 45.3 \\
\hline Unfinished 4B & 24.0 & N/A & N/A & N/A \\
\hline Unfinished 4C & 14.7 & N/A & N/A & N/A \\
\hline Unfinished 5B & 25.4 & N/A & N/A & N/A \\
\hline $\mathbf{6 A}$ & 33.9 & N/A & N/A & N/A \\
\hline $\mathbf{6 B}$ & 23.3 & 21.6 & N/A & N/A \\
\hline 7A & 23.9 & 23.0 & N/A & N/A \\
\hline 7B & 19.2 & 15.7 & N/A & N/A \\
\hline KA & 33.7 & 26.8 & N/A & N/A \\
\hline RB & 17.2 & 24.8 & N/A & N/A \\
\hline RC & 2.66 & 2.80 & N/A & N/A \\
\hline Upper Fountain & 11.3 & 7.45 & N/A & N/A \\
\hline Princess Fountain & 17.1 & 14.7 & N/A & N/A \\
\hline & & & &
\end{tabular}

A map showing the capacity of each channel under both flow depth conditions as well as a map showing optimal flow requirements for all fountains is shown in Figures 40 - 45 in Appendix 2.

Using Equation 6, the minimum self-cleaning velocities calculated for the soil found at the site are tabulated in Table 7. Note: The "cleaning" velocity was calculated with respect to a minimum, mid-range, and maximum diameter for each soil. The absolute maximum velocity required to prevent sediment build up under all soil conditions in the channels is approximately $0.1 \mathrm{~m} / \mathrm{s}$.

Table 7: Minimum Self-Cleaning Velocities

\begin{tabular}{|l|c|c|c|c|c|c|c|}
\hline & $\mathbf{G}$ & $\begin{array}{c}\mathbf{d}_{\text {min }} \\
(\mathbf{m m})\end{array}$ & $\begin{array}{c}\mathbf{d}_{\text {mid }} \\
(\mathbf{m m})\end{array}$ & $\begin{array}{c}\mathbf{d}_{\text {max }} \\
(\mathbf{m m})\end{array}$ & $\begin{array}{c}\mathbf{v}_{\text {min }} \\
(\mathbf{m} / \mathbf{s})\end{array}$ & $\begin{array}{c}\mathbf{v}_{\text {mid }} \\
(\mathbf{m} / \mathbf{s})\end{array}$ & $\begin{array}{c}\mathbf{v}_{\text {max }} \\
(\mathbf{m} / \mathbf{s})\end{array}$ \\
\hline clay & 2.67 & - & - & 0.002 & - & - & 0.012 \\
\hline silt & 2.70 & 0.002 & 0.025 & 0.05 & 0.013 & 0.039 & 0.053 \\
\hline fine sand & 2.70 & 0.05 & 0.15 & 0.25 & 0.053 & 0.086 & 0.107 \\
\hline
\end{tabular}


Table 5 displays the sediment transport parameters described by Chanson (2009) for each channel. These values were calculated through simulating the flow required for each fountain to operate optimally. This flow scenario models the distribution of $50 \mathrm{gpm}, 105 \mathrm{gpm}$, and 30 gpm from sources 1,2 , and 3 respectively.

Table 8: Sediment Transport Parameters

\begin{tabular}{|r|r|r|r|}
\hline Channel & \multicolumn{1}{|c|}{ v $^{*}$} & \multicolumn{1}{c|}{$\boldsymbol{\tau}^{*}$} & \multicolumn{1}{c|}{ Re $^{*}$} \\
\hline C1 & 0.079 & 1.52 & 19.6 \\
\hline C2 & 0.058 & 0.818 & 14.4 \\
\hline C3 & 0.091 & 2.04 & 22.7 \\
\hline C4 & 0.113 & 3.11 & 28.0 \\
\hline C5 & 0.166 & 6.71 & 41.1 \\
\hline C6 & 0.108 & 2.87 & 26.9 \\
\hline C7 & 0.129 & 4.07 & 32.1 \\
\hline C8 & 0.117 & 3.35 & 29.1 \\
\hline C9 & 0.133 & 4.31 & 33.0 \\
\hline C10 & 0.157 & 5.99 & 38.9 \\
\hline C11 & 0.133 & 4.31 & 33.0 \\
\hline C12 & 0.117 & 3.35 & 29.1 \\
\hline C13 & 0.099 & 2.40 & 24.6 \\
\hline C14 & 0.094 & 2.16 & 23.3 \\
\hline C15 & 0.070 & 1.20 & 17.4 \\
\hline C16 & 0.066 & 1.08 & 16.5 \\
\hline C17 & 0.133 & 4.31 & 33.0 \\
\hline C18 & 0.117 & 3.35 & 29.1 \\
\hline C19 & 0.063 & 0.958 & 15.6 \\
\hline C20 & 0.065 & 1.02 & 16.0 \\
\hline
\end{tabular}

\section{Discussion}

By analyzing the capacities of each channel in succession throughout the system, the team was able to model the total capacity of the system. First, the total flow to the Upper Misana is not limited by the capacity of Channel $\mathrm{C} 1$ but instead by the summation of Channels $\mathrm{C} 2$ and C3. For $50 \%$ flow depth the combined capacity is approximately $30 \mathrm{gpm}$ and for $80 \%$ depth it is 60 gpm. Flow to the Lower Misana is then limited by this capacity added to the capacity of Channels C9 and C12. The Lower Misana can at most handle approximately $420 \mathrm{gpm}$ or 230 gpm depending on flow depth.

For the Fountain House Complex, flow is limited by the capacity of the feed channel to each fountain. In summation, theses channels (Channels C15, C16, C17, and C18) have a capacity of $92 \mathrm{gpm}$ and $49 \mathrm{gpm}$ for the respective flow depth scenarios. Since excavation around the Princess Fountain is ongoing, the capacity for the whole system can only be estimated based 
upon the direct feed channels to the two fountains. These feed channels combined can at most handle $35 \mathrm{gpm}$ and $20 \mathrm{gpm}$.

Next, comparing channel capacities to the optimal flow required for each fountain gives an understanding of what/how many fountains can simultaneously operate (Note: If multiple flow techniques were used at a fountain, flow calculated by the Woodburn Equation is used as the best estimate). Looking at the flow requirements, several limitations can be seen. First of all, Channel C3 can only support optimal flow at Fountain $4 \mathrm{~A}\left(\mathrm{Q}_{\mathrm{req}}=30 \mathrm{gpm}\right)$ if it has an $80 \%$ flow depth. Also, C3 ( $\left.\mathrm{Q}_{\text {cap }}=40 \mathrm{gpm}\right)$ can either support Fountain $4 \mathrm{~A}$ or a combination of unfinished Fountain $4 \mathrm{~B}\left(\mathrm{Q}_{\mathrm{req}}=25 \mathrm{gpm}\right)$ and unfinished Fountain $4 \mathrm{C}\left(\mathrm{Q}_{\mathrm{req}}=15 \mathrm{gpm}\right)$. All three of these fountains cannot operate fully at the same time.

At the Lower Misana, the three conduits can supply adequate flow for all six fountains to simultaneously behave optimally. Flow required for Fountains 5A, 5B, 6A, 6B, 7A, and 7B to all operated is approximately $155 \mathrm{gpm}$. This scenario is possible only due to a second source of water, currently the Manyaraki Canal, being fed into Channels C9 and C12. The fountains in the Lower Misana could not all operate if the sole source of water entered the system via Channel C1. However, with a dual source system the additional flow can be distributed as necessary.

The Manyaraki and Princess Complexes are both able to support sufficient flow for each of their fountains. For the Fountain House Complex, regardless of flow scenario (i.e. whether $50 \%$ or $80 \%$ depth of flow) each feed channel can transmit optimal flow to its connecting fountain. The Princess Fountain, however, requires a higher capacity scenario in order to meet optimal flow to both the Upper and Princess Fountains.

Next, flow velocities for channel capacities were compared to scour and flow condition parameters. In each channel, velocities were lower than the minimum velocity required for scour to occur. Looking at Table $3, \mathrm{v}_{\text {scour }}$ for hard rock is nearly $4 \mathrm{~m} / \mathrm{s}$ which is an order of magnitude higher than any of the maximum velocities carried. Comparing the flow velocity of each channel in the 3 complexes, it can be seen that each channel has subcritical flow.

The maximum velocity required for self-cleaning channels calculated by the Timmons and Youngs method (1991) was $0.1 \mathrm{~m} / \mathrm{s}$. Flow through all channels was able to meet this requirement. Looking at the sediment transport method described by Chanson (2009), the parameters for each channel correspond to sediment motion. Both of these methods show that the channels were able to prevent build up of sediment.

The simulation model also helped to depict important design aspects of the site. Through running various no flow scenarios in the model, it can be seen that the total system can also act as discrete control volumes. For instance, if flow to Channels C7, C8, C10, and C12 is shut then the Upper Misana can operate as a separate entity. Once flow runs through the first six fountains it can be funneled through Channel C7 and then C9 and be deposited out of the site. Flow can also be shut to Channel $\mathrm{C} 1$ in order to allow only the Lower Misana to operate. Other scenarios can be created by using one of the 15 valves to shut flow to various channels. 
Simulated flow to unfinished Fountains 5A and 5B can be applied or stopped. Flow can also be stopped from feeding Fountain 4A and unfinished Fountains $4 \mathrm{~B}$ and 4C depending on the behavior desired. Note, a constraint to the system is added since the capacity of Channel C3 can only supply adequate flow to either Fountain 4A or to both Fountains 4B and 4C.

One flow scenario is allowing flow to all fountains on site. This would model how the site would behave if construction had finished. The unfinished fountains can be modeled with the simulation model and behavior of the entire site can be analyzed. Modeling this scenario shows that flow cannot adequately be supplied to Fountains $4 \mathrm{~A}, 4 \mathrm{~B}$ and $4 \mathrm{C}$. The additional unfinished Fountains 5A and 5B can be adequately fed without negatively affecting the behavior of the other fountains in the network. This is due to the secondary source from the Manyaraki canal and the large capacities of Conduits 1, 2, and 3.

A second scenario is shutting flow to unfinished Fountains 4B, 4C, 5A and 5B. This scenario represents how the site currently would distribute flow. All fountains can receive adequate flow for optimal behavior. This scenario can be used to better calibrate the model. By running controlled tests, fountain behavior in the model can be adjusted to better represent behavior seen in the field.

Due to the limitation of Channel C3, either Channels C4 and C6 or Channel C5 has to be shut. In the former case, the simulation shows that Fountain $4 \mathrm{~A}$ can be adequately fed if Fountains $4 \mathrm{~B}$ and $4 \mathrm{C}$ were not operating. The latter case allows Fountains $4 \mathrm{~B}$ and $4 \mathrm{C}$ to operate ideally since flow is not diverted to Fountain 4A. These two results help explain the relationship of Fountains $4 \mathrm{~A}, 4 \mathrm{~B}$, and $4 \mathrm{C}$ to the capacities of their feed channels.

By relating the results from the field tests and simulation model, it is evident that a multitude of hydraulic properties could be met while ample flow to fountains throughout the system could also be supplied. Both the simulation model and results from field tests show evidence that the Inca designed the fountains, drops, and channels and Ollantaytambo to meet these desired criteria.

\section{Future work}

For future research, work to be done at the site could be the excavation of the area just to the north of the fountain house. This may be beneficial for better understanding the site's hydraulics and may not make sense from an archaeological perspective. The ground level at Inca times is estimated to be approximately 8 feet below the current ground level. This area lies between the Inkamisana and the Fountain House. It may have a hydraulic relationship to either of these areas as well as the Princess Fountain Complex. Another area for further excavation is the area north of the Princess Fountain Complex. This work is essential in order to determine the water supply network used for the complex. The fountain is currently fed from the modern canal but the original source is unknown. Only a small portion of the supply network currently used to feed the complex is original. Excavation may take years to complete but the possible findings would be crucial to completing the hydraulic analysis of the Ollantaytambo flow networks. A finalized layout of the entire site, as originally designed, could then be completed. 
Additional work can be done to improve the code used in the simulation model. Kesserwani et al (2010) developed a method for approximating flow distribution of channels intersection at right angles. This method may be a more accurate estimation for flow distribution between channels joined at a junction. Further study of this approach would be necessary in order to change the model's code. Another way to improve the code would be a more detailed survey of channel intersections. The relationship between channel bed elevations is essential to improving the flow distribution between channels at a junction. This detailed survey would also be essential in applying the method devised by Kesserwani et al (2010). Calibration of the model should also be done. Calibration would be based upon the actual site behavior of fountains and channels under controlled conditions. Additional flow measurements of the channels and fountains would need to be conducted in order to complete this process. If further excavation is completed, the model layout would have to be revised. Any additional hydraulic elements (e.g. channels and fountains) would be included in the simulation.

To further the comprehensive representation of the site, ArcGIS can be utilized. ArcGIS is a powerful mapping and modeling program. One of its major strengths is the ability to project data with no relative location information into a pre-defined coordinate system. Layout plans and elevation diagrams can be uploaded into GIS and incorporated into real map projections. For instance, surveying data from the Inkamisana can be projected into a coordinate system that relates its location relative to other Incan ruins in Peru. Another important aspect of GIS is its ability to relate multiple data layers to each other. This means the watershed analysis done by Sollner (2011-2012) can be directly related to the hydraulic study of the Inkamisana Complex.

\section{Conclusion}

The network of channels and fountains in the Inkamisana is intimately connected to the Patacancha watershed. Fountains located within these complexes require a reliable source of water sufficient enough to meet optimal flow requirements. Sollner's (2011-2012) research shows the ability for the Patacancha watershed to supply adequate water to canals built along the valley. Two of these canals travel down the Patacancha Valley and end up supplying the Inkamisana Complexes at two distinct points. One of the canals is a diversion from the Patacancha River and later splits into two different canals (i.e. the Huaca and Manyaraki Canals) and the other a canal stemming from the Media Luna stream (i.e. the Bandolista Canal). Dual water sources may have helped to adjust for seasonal flow variations as well as the hydraulic distribution constraints within the flow networks. The Huaca and Bandolista Canals combine near the Inkamisana bifurcation and feed the Upper Misana (Fountains 1, 2, 3, 4A, 4B, and 4C). Water from the Manyaraki Canal joins the system at the junction of Channels C9 and C12 and helps supply the Lower Misana (Fountains 5A, 5B, 6A, 6B, 7A, and 7B). Water output from the Lower Misana feeds the Fountain House Complex (King's Bath and Rock Fountain) before leaving the site entirely. The Princess Fountain Complex is currently fed from the Manyaraki Canal downstream of the previous source point.

Extensive tests were run to analyze the behavior of flow throughout the Inkamisana. Dye tracing was used to track flow paths throughout the system as well as to measure optimal flow rates to fountains. Optimal flow was defined by field engineers by comparing the behavior of 
similarly designed Inca fountains. Ping-pong balls, buckets, and a numerical technique were also used to estimate flow rates. These tests were able to show that flow supplied by the source canals were sufficient for fountains to behave optimally. Velocity and flow rate capacities of all channels were estimated based upon design parameters such as slope, channel roughness, and geometry. A simulation model was also designed to mimic the flow behavior throughout each network. Data collected in the field helped to accurately model each channel and fountain's behavior. Addition of valve control of specific channels and source modification allowed for a sensitivity analysis of the system. This approach better represented the operational behavior of the site during Inca occupancy. For both the field data and simulation outputs, other hydraulic parameters were also analyzed. Scour velocity, selfcleaning behavior, and flow characterization were compared to velocities in each channel estimated by both approaches. Amazingly, these three parameters could be optimized while still maintaining adequate flow to each fountain. These finding helped show that the Inca truly had an intuitive understanding of hydraulic principles.

This understanding allowed the Inca to design a hydraulically balanced system. Based upon Sollner's research (2011-2012), the combined capacities of the Huaca, Bandolista, and Manyaraki Canals could have fed all fountains at the site with excess water for other uses. Fountains in the Upper and Lower complexes could have been adequately supplied by the Huaca canal. The Inca could have carried the Bandolista canal to be a secondary source for the Lower Misana. Channels near the bifurcation of the Inkamisana are the limiting factor of flow to the Upper Misana. The unfinished Fountains 5A and 5B were meant to be hydraulically similar to Fountains 6A, 6B, 7A, and 7B. There is evidence (both its proximity and current lack of use) that Conduit 1 was intended to feed these unfinished fountains. Flow rate estimations show that there is adequate flow leaving the Lower Misana to feed the King's Bath and Rock Fountain with excess for other use further down site. Design of fountains throughout the site for aesthetic pleasure can be seen through the Woodburn analysis. Future analysis of flow estimation for Inca sites can be done through several steps. Estimation of channel geometry and properties are needed for the Manning's method of flow capacity. Fountain geometry and sprout cross sections are needed for jet analysis. Additional flow parameters can be estimated based upon these properties and through charts and tables used in this research. 


\section{References}

Chanson, Hubert. The Hydraulics of Open Channel Flow: An introduction. New York: John Wiley \& Sons Inc., 1999. Print.

Crowe, C., Elger, D., Williams, B., \& Roberson, J. (2009). Engineering Fluid Mechanics (9 ed.). Jefferson City: John Wiley \& Sons, Inc..

D’Altroy, T. (2002). The Incas. Malden, MA Blackwell Publishing.

Farrington, I. (1980). The Archaeology of Irrigation Canals, with Special Reference to Peru. World Archaeology, 2(No. 3), 287-305. Retrieved May 20, 2012, from the JSTOR database.

Guo, J., 2002. Hunter Rouse and Shields diagram. In: Advances in Hydraulics and Water Engineering, Proceedings of the 13th IAHR-APD Congress, vol. 2, pp. 1096-1098.

Kesserwani, G., Vazquez, J., Rivière, N., Liang, Q., Travin, G., \& Mosé, R. (2010). New Approach for Predicting Flow Bifurcation. Journal of Hydraulic Engineering, 10. Retrieved November 8, 2012, from http://www.hach.ulg.ac.be

MacQuarrie, K. (2007). The Last Days of the Incas. (1st ed.). New York, New York: Simon \& Shuster Paperbacks.

Mays, Larry. Water Resources Engineering. Phoenix: John Wiley \& Sons, Inc., 2005 Print.

Mazadiego, L., Puche, O., \& Hervas, A. (2009). Water and Inca cosmogony: myths, geology, and engineering in the Peruvian Andes. Geological Society, London, Special Publications, 310. Retrieved November 21, 2012, from http://sp.lyellcollection.org/

Namnama, K., DeGuzman, K. (2000). The Inca Empire K12, USA

Niles, S. A. (1987). Callachaca Style and Status in an Inca Community. Iowa City, IA: University of Iowa Press.

Protzen, J. (1993). Inca Architecture and Construction at Ollantaytambo. New York, NY: Oxford University Press.

Timmons, M.B. and W.D. Youngs. (1991) Considerations on the design of raceways, from ASAE Special Publication \#701: Aquaculture Systems Engineering, Proceedings from World Aquaculture Society, World Aquaculture 91, June 15-22, 1991, San Juan, Puerto Rico

Turbulent flow is slower than laminar flow | lorem ipsum. (n.d.). lorem ipsum. Retrieved November 27, 2012, from http://blog.nialbarker.com/252/slow_is_fa 
Water - Dynamic and Kinematic Viscosity . (n.d.). Engineering ToolBox . Retrieved November 27, 2012, from http://www.engineeringtoolbox.com/water-dynamickinematic-viscosity-d_596.html

Wright, K. R., Wright, R. M., Zegarra, A. V., \& McEwan, G. (2011).Moray: Inca Engineering Mystery. (1st ed.). Reston, Virginia: American Society of Civil Engineers.

Wright, K. R. (2006). Tipon: Water Engineering Masterpiece of the Inca Empire. (1st ed.). Reston, Virginia: American Society of Civil Engineers .

Wright, K. M., \& Zegarra, A. V. (2000). Machu Picchu: A Civil Engineering Marvel. (1st ed.). Reston, Virginia: American Society of Civil Engineers.

Wurbs, Ralph, and Wesley James. Water Resources Engineering. College Station: Prentice Hall, 2002. Print. 


\section{Appendix I}

Table 9: Test 1 Velocity Measurements - optimal flow to fountains 1-3 and 4A

\begin{tabular}{|c|r|r|r|}
\hline & $\begin{array}{c}\Delta \mathbf{t} \\
(\mathbf{s e c})\end{array}$ & $\Delta \mathbf{x}(\mathbf{m})$ & $\begin{array}{c}\text { velocity } \\
(\mathbf{m} / \mathbf{s})\end{array}$ \\
\hline \multirow{3}{*}{$\begin{array}{c}\text { ping pong } \\
\text { ball tests }\end{array}$} & N/A & N/A & N/A \\
\cline { 2 - 4 } & N/A & N/A & N/A \\
\hline average & N/A & N/A & N/A \\
\hline \multirow{3}{*}{$\begin{array}{c}\text { dye trace } \\
\text { tests }\end{array}$} & 9.78 & 5.90 & N/A \\
\cline { 2 - 4 } & 9.82 & 5.90 & 0.60 \\
\hline average & 9.90 & 5.90 & 0.60 \\
\hline & $\mathbf{9 . 8 3}$ & $\mathbf{5 . 9 0}$ & $\mathbf{0 . 6 0}$ \\
\hline
\end{tabular}

Table 10: Test 1 Flow Rate Calculations - optimal flow to fountains 1-3 and 4A

\begin{tabular}{|l|r|r|r|r|r|r|}
\hline & $\begin{array}{c}\text { flow depth } \\
(\mathbf{c m})\end{array}$ & $\begin{array}{c}\text { channel } \\
\text { width } \mathbf{( c m})\end{array}$ & $\begin{array}{c}\text { max channel } \\
\text { height } \mathbf{( c m )}\end{array}$ & $\begin{array}{c}\text { Flow Area } \\
\left(\mathbf{c m}^{\mathbf{2}}\right)\end{array}$ & $\begin{array}{c}\text { Max Channel } \\
\left.\text { Area } \mathbf{( c m}^{\mathbf{2}}\right)\end{array}$ & $\begin{array}{c}\text { Qmeasured } \\
(\mathbf{g p m})\end{array}$ \\
\hline & 12.50 & 53.00 & 38.00 & 662.50 & 2014.00 & 630.12 \\
\hline & 7.00 & 73.00 & 37.00 & 511.00 & 2701.00 & 486.02 \\
\hline & 17.00 & 70.00 & 32.00 & 1190.00 & 2240.00 & 1131.83 \\
\hline Average & $\mathbf{1 2 . 1 7}$ & $\mathbf{6 5 . 3 3}$ & $\mathbf{3 5 . 6 7}$ & $\mathbf{7 8 7 . 8 3}$ & $\mathbf{2 3 1 8 . 3 3}$ & $\mathbf{7 4 9 . 3 2}$ \\
\hline
\end{tabular}

Table 11: Test 2 Velocity Measurements - optimal flow to fountains 1-3 and 4A

\begin{tabular}{|c|c|r|r|}
\hline & $\begin{array}{c}\Delta \mathbf{t} \\
(\mathbf{s e c})\end{array}$ & $\Delta \mathbf{x} \mathbf{( m )}$ & $\begin{array}{c}\text { velocity } \\
(\mathbf{m} / \mathbf{s})\end{array}$ \\
\hline \multirow{3}{*}{$\begin{array}{c}\text { ping pong } \\
\text { ball tests }\end{array}$} & 15.98 & 15.00 & 0.94 \\
\cline { 2 - 4 } & 15.67 & 15.00 & 0.96 \\
\hline average & $\mathbf{1 5 . 8 5}$ & $\mathbf{1 5 . 0 0}$ & $\mathbf{0 . 9 5}$ \\
\hline \multirow{2}{*}{$\begin{array}{c}\text { dye trace } \\
\text { tests }\end{array}$} & 16.01 & 15.00 & 0.94 \\
\cline { 2 - 4 } & 16.10 & 15.00 & 0.93 \\
\hline average & 15.83 & 15.00 & 0.95 \\
\hline
\end{tabular}


Table 12: Test 2 Flow Rate Calculations - optimal flow to fountains 1-3 and 4A

\begin{tabular}{|r|r|r|r|r|r|r|}
\hline & $\begin{array}{c}\text { flow depth } \\
(\mathbf{c m})\end{array}$ & $\begin{array}{c}\text { channel } \\
\text { width } \mathbf{( c m})\end{array}$ & $\begin{array}{c}\text { max channel } \\
\text { height } \mathbf{( c m})\end{array}$ & $\begin{array}{c}\text { Flow Area } \\
\left(\mathbf{c m}^{\mathbf{2}}\right)\end{array}$ & $\begin{array}{c}\text { Max Channel } \\
\left.\text { Area } \mathbf{( c m}^{\mathbf{2}}\right)\end{array}$ & $\begin{array}{c}\text { Qmeasured } \\
(\mathbf{g p m})\end{array}$ \\
\hline & 3.00 & 20.00 & 10.00 & 60.00 & 200.00 & 89.72 \\
\hline & 1.50 & 27.00 & 10.00 & 40.50 & 270.00 & 60.55 \\
\hline & 2.00 & 22.00 & 9.00 & 44.00 & 198.00 & 65.79 \\
\hline Average & $\mathbf{2 . 1 7}$ & $\mathbf{2 3 . 0 0}$ & $\mathbf{9 . 6 7}$ & $\mathbf{4 8 . 1 7}$ & $\mathbf{2 2 2 . 6 7}$ & $\mathbf{7 1 . 9 7}$ \\
\hline
\end{tabular}

Table 13: Test 3 Velocity Measurements - optimal flow to fountains 1-3 and 4A

\begin{tabular}{|c|c|r|r|}
\hline & $\begin{array}{c}\Delta \mathbf{t} \\
(\mathbf{s e c})\end{array}$ & $\Delta \mathbf{x} \mathbf{( m )}$ & $\begin{array}{c}\text { velocity } \\
(\mathbf{m} / \mathbf{s})\end{array}$ \\
\hline \multirow{3}{*}{$\begin{array}{c}\text { ping pong } \\
\text { ball tests }\end{array}$} & 18.62 & 15.00 & 0.81 \\
\cline { 2 - 4 } & 17.75 & 15.00 & 0.85 \\
\hline average & 18.29 & 15.00 & 0.82 \\
\hline \multirow{3}{*}{$\begin{array}{c}\mathbf{1 8 . 2 2} \\
\text { dye trace }\end{array}$} & 18.55 & 15.00 & $\mathbf{0 . 8 2}$ \\
\cline { 2 - 4 } tests & 18.02 & 15.00 & 0.81 \\
\cline { 2 - 4 } & 17.95 & 15.00 & 0.83 \\
\hline average & $\mathbf{1 8 . 1 7}$ & $\mathbf{1 5 . 0 0}$ & $\mathbf{0 . 8 3}$ \\
\hline
\end{tabular}

Table 14: Test 3 Flow Rate Calculations - optimal flow to fountains 1-3 and 4A

\begin{tabular}{|r|r|r|r|r|r|r|}
\hline & $\begin{array}{c}\text { flow depth } \\
(\mathbf{c m})\end{array}$ & $\begin{array}{c}\text { channel } \\
\text { width } \mathbf{( c m})\end{array}$ & $\begin{array}{c}\text { max channel } \\
\text { height } \mathbf{( c m})\end{array}$ & $\begin{array}{c}\text { Flow Area } \\
\left(\mathbf{c m}^{\mathbf{2}}\right)\end{array}$ & $\begin{array}{c}\text { Max Channel } \\
\text { Area }\left(\mathbf{c m}^{\mathbf{2}}\right)\end{array}$ & $\begin{array}{c}\text { Qmeasured } \\
(\mathbf{g p m})\end{array}$ \\
\hline & 1.00 & 27.00 & 10.00 & 27.00 & 270.00 & 35.35 \\
\hline & 1.20 & 24.00 & 9.00 & 28.80 & 216.00 & 37.57 \\
\hline & 1.40 & 21.00 & 11.00 & 29.40 & 231.00 & 38.36 \\
\hline average & $\mathbf{1 . 2 0}$ & $\mathbf{2 4 . 0 0}$ & $\mathbf{1 0 . 0 0}$ & $\mathbf{2 8 . 4 0}$ & $\mathbf{2 3 9 . 0 0}$ & $\mathbf{3 7 . 0 9}$ \\
\hline
\end{tabular}


Table 15: Test 4 Velocity Measurements - optimal flow to fountains 1-3 and 4A

\begin{tabular}{|c|r|r|r|}
\hline & $\begin{array}{c}\Delta \mathbf{t} \\
(\mathbf{s e c})\end{array}$ & $\Delta \mathbf{x}(\mathbf{m})$ & $\begin{array}{c}\text { velocity } \\
(\mathbf{m} / \mathbf{s})\end{array}$ \\
\hline & 5.78 & 4.10 & 0.71 \\
\cline { 2 - 4 } ping pong & 5.91 & 4.10 & 0.69 \\
\cline { 2 - 4 } ball tests & 5.34 & 4.10 & 0.77 \\
\hline average & $\mathbf{5 . 6 8}$ & $\mathbf{4 . 1 0}$ & $\mathbf{0 . 7 2}$ \\
\hline \multirow{3}{*}{$\begin{array}{c}\text { dye trace } \\
\text { tests }\end{array}$} & 5.34 & 4.10 & 0.77 \\
\cline { 2 - 4 } & 5.56 & 4.10 & 0.74 \\
\hline average & 5.62 & 4.10 & 0.73 \\
\hline & $\mathbf{5 . 5 1}$ & $\mathbf{4 . 1 0}$ & $\mathbf{0 . 7 4}$ \\
\hline
\end{tabular}

Table 16: Test 4 Flow Rate Calculations - optimal flow to fountains 1-3 and 4A

\begin{tabular}{|r|r|r|r|r|r|r|}
\hline & $\begin{array}{c}\text { flow depth } \\
(\mathbf{c m})\end{array}$ & $\begin{array}{c}\text { channel } \\
\text { width }(\mathbf{c m})\end{array}$ & $\begin{array}{c}\text { max channel } \\
\text { height } \mathbf{( c m )}\end{array}$ & $\begin{array}{c}\text { Flow Area } \\
\left(\mathbf{c m}^{\mathbf{2}}\right)\end{array}$ & $\begin{array}{c}\text { Max Channel } \\
\text { Area }\left(\mathbf{c m}^{\mathbf{2}}\right)\end{array}$ & $\begin{array}{c}\text { Qmeasured } \\
(\mathbf{g p m})\end{array}$ \\
\hline & 3.50 & 9.00 & 7.00 & 31.50 & 63.00 & 36.62 \\
\hline & 2.50 & 10.00 & 8.00 & 25.00 & 80.00 & 29.17 \\
\hline & 6.50 & 8.00 & 10.00 & 52.00 & 80.00 & 60.55 \\
\hline Average & $\mathbf{4 . 1 7}$ & $\mathbf{9 . 0 0}$ & $\mathbf{8 . 3 3}$ & $\mathbf{3 6 . 1 7}$ & $\mathbf{7 4 . 3 3}$ & $\mathbf{4 2 . 1 7}$ \\
\hline
\end{tabular}

Table 17: Test 5 Velocity Measurements - optimal flow to fountains 1-3 and 4A

\begin{tabular}{|c|r|r|r|}
\hline & $\begin{array}{c}\Delta \mathbf{t} \\
(\mathbf{s e c})\end{array}$ & $\Delta \mathbf{x}(\mathbf{m})$ & $\begin{array}{c}\text { velocity } \\
(\mathbf{m} / \mathbf{s})\end{array}$ \\
\hline \multirow{4}{*}{$\begin{array}{c}\text { ping pong } \\
\text { ball tests }\end{array}$} & 3.53 & 1.29 & 0.37 \\
\cline { 2 - 4 } & 3.84 & 1.29 & 0.34 \\
\hline average & 3.50 & 1.29 & 0.37 \\
\hline \multirow{3}{*}{$\begin{array}{c}\text { dye trace } \\
\text { tests }\end{array}$} & 2.90 & $\mathbf{1 . 2 9}$ & $\mathbf{0 . 3 6}$ \\
\cline { 2 - 4 } & 3.22 & 1.29 & 0.44 \\
\cline { 2 - 4 } & 2.88 & 1.29 & 0.40 \\
\hline average & $\mathbf{3 . 0 0}$ & $\mathbf{1 . 2 9}$ & 0.45 \\
\hline
\end{tabular}


Table 18: Test 5 Flow Rate Calculations - optimal flow to fountains 1-3 and 4A

\begin{tabular}{|l|r|r|r|r|r|r|}
\hline & $\begin{array}{c}\text { flow depth } \\
\text { (cm) }\end{array}$ & $\begin{array}{c}\text { channel } \\
\text { width }(\mathbf{c m})\end{array}$ & $\begin{array}{c}\text { max channel } \\
\text { height }(\mathbf{c m})\end{array}$ & $\begin{array}{c}\text { Flow Area } \\
\left(\mathbf{c m}^{\mathbf{2}}\right)\end{array}$ & $\begin{array}{c}\text { Max Channel } \\
\text { Area }\left(\mathbf{c m}^{\mathbf{2}}\right)\end{array}$ & $\begin{array}{c}\text { Qmeasured } \\
(\mathbf{g p m})\end{array}$ \\
\hline & 2.50 & 6.50 & 8.00 & 16.25 & 52.00 & 10.15 \\
\hline & 2.50 & 7.00 & 9.00 & 17.50 & 63.00 & 10.94 \\
\hline & 2.00 & 7.00 & 7.00 & 14.00 & 49.00 & 8.72 \\
\hline Average & $\mathbf{2 . 3 3}$ & $\mathbf{6 . 8 3}$ & $\mathbf{8 . 0 0}$ & $\mathbf{1 5 . 9 2}$ & $\mathbf{5 4 . 6 7}$ & $\mathbf{9 . 9 9}$ \\
\hline
\end{tabular}

Table 19: Test 6 Velocity Measurements - optimal flow to fountains 1-3 and 4A

\begin{tabular}{|c|r|r|r|}
\hline \multirow{3}{*}{$\begin{array}{c}\text { ping pong } \\
\text { ball tests }\end{array}$} & $\begin{array}{c}\Delta \mathbf{t} \\
(\mathbf{s e c})\end{array}$ & $\Delta \mathbf{x} \mathbf{( m )}$ & $\begin{array}{c}\text { velocity } \\
(\mathbf{m} / \mathbf{s})\end{array}$ \\
\cline { 2 - 4 } & 1.53 & 1.82 & 1.19 \\
\cline { 2 - 4 } & 1.75 & 1.82 & 1.04 \\
\cline { 2 - 4 } & 1.67 & 1.82 & 1.09 \\
\cline { 2 - 4 } & 1.69 & 1.82 & 1.08 \\
\hline \multirow{3}{*}{$\begin{array}{c}\text { dye trace } \\
\text { tests }\end{array}$} & 1.72 & 1.82 & 1.06 \\
\cline { 2 - 4 } & 1.72 & 1.82 & $\mathbf{1 . 0 9}$ \\
\cline { 2 - 4 } & 1.72 & 1.82 & 1.16 \\
\hline \multirow{2}{*}{ average } & 1.68 & 1.82 & 1.06 \\
\hline \multirow{2}{*}{ average } & $\mathbf{1 . 6 7}$ & $\mathbf{1 . 8 2}$ & 1.06 \\
\hline
\end{tabular}

Table 20: Test 6 Flow Rate Calculations - optimal flow to fountains 1-3 and 4A

\begin{tabular}{|l|r|r|r|r|r|r|}
\hline & $\begin{array}{c}\text { flow depth } \\
(\mathbf{c m})\end{array}$ & $\begin{array}{c}\text { channel } \\
\text { width }(\mathbf{c m})\end{array}$ & $\begin{array}{c}\text { max channel } \\
\text { height }(\mathbf{c m})\end{array}$ & $\begin{array}{c}\text { Flow Area } \\
\left(\mathbf{c m}^{\mathbf{2}}\right)\end{array}$ & $\begin{array}{c}\text { Max Channel } \\
\text { Area }\left(\mathbf{c m}^{\mathbf{2}}\right)\end{array}$ & $\begin{array}{c}\text { Qmeasured } \\
(\mathbf{g p m})\end{array}$ \\
\hline & 2.00 & 15.00 & 13.00 & 30.00 & 195.00 & 50.73 \\
\hline & 1.50 & 15.00 & 14.00 & 22.50 & 210.00 & 38.04 \\
\hline Average & 2.00 & 13.00 & 16.00 & 26.00 & 208.00 & 44.07 \\
\hline
\end{tabular}


Table 21: Test 8 Transit Time and Average Velocity

\begin{tabular}{|c|r|r|r|r|}
\hline & spot 1 & spot 2 & spot 3 & spot 4 \\
\hline \multirow{2}{*}{$\begin{array}{c}\text { cumulative } \\
\Delta \mathbf{t}(\mathbf{s e c})\end{array}$} & 38.28 & 108.00 & 111.00 & 123.00 \\
\cline { 2 - 5 } & 36.10 & 109.00 & 112.00 & 121.00 \\
\cline { 2 - 5 } & 37.63 & 107.00 & 113.00 & 119.00 \\
\hline average $\Delta \mathbf{t}(\mathbf{s e c})$ & $\mathbf{3 7 . 3 4}$ & $\mathbf{1 0 8 . 0 0}$ & $\mathbf{1 1 2 . 0 0}$ & $\mathbf{1 2 1 . 0 0}$ \\
\hline $\begin{array}{c}\text { cumulative } \Delta \mathbf{x} \\
(\mathbf{m})\end{array}$ & 35.30 & 84.50 & 87.10 & 89.40 \\
\hline average $\mathbf{~}(\mathbf{m} / \mathbf{s})$ & $\mathbf{0 . 9 5}$ & $\mathbf{0 . 7 8}$ & $\mathbf{0 . 7 8}$ & $\mathbf{0 . 7 4}$ \\
\hline
\end{tabular}

Table 22: Test 9 Transit Time and Average Velocity

\begin{tabular}{|c|r|r|r|r|}
\hline & spot 1 & \multicolumn{1}{|c|}{ spot 2 } & spot 3 & spot 4 \\
\hline \multirow{2}{*}{$\begin{array}{c}\text { cumulative } \\
\Delta \mathbf{t} \text { (sec) }\end{array}$} & 30.32 & 58.00 & 109.00 & 114.00 \\
\cline { 2 - 5 } & 28.72 & 55.00 & 103.00 & 107.00 \\
\cline { 2 - 5 } & 28.06 & 54.00 & 99.00 & 105.00 \\
\hline average $\Delta \mathbf{t}$ & $\mathbf{2 9 . 0 3}$ & $\mathbf{5 5 . 6 7}$ & $\mathbf{1 0 3 . 6 7}$ & $\mathbf{1 0 8 . 6 7}$ \\
\hline $\begin{array}{c}\text { cumulative } \Delta \mathbf{x} \\
(\mathbf{m})\end{array}$ & 18.47 & 33.00 & 59.00 & 61.17 \\
\hline average v (m/s) & $\mathbf{0 . 6 4}$ & $\mathbf{0 . 5 9}$ & $\mathbf{0 . 5 7}$ & $\mathbf{0 . 5 6}$ \\
\hline
\end{tabular}

Table 23: Test 10 Transit Time and Average Velocity

Table 23: Test 10 Transit Time and Average Velocity
\begin{tabular}{|c|r|r|}
\hline \multirow{2}{*}{$\begin{array}{c}\text { cumulative } \\
\Delta \mathbf{t}(\mathbf{s e c})\end{array}$} & spot $\mathbf{1}$ & spot $\mathbf{2}$ \\
\cline { 2 - 3 } & 33.44 & 110.00 \\
\cline { 2 - 3 } & 31.72 & 107.00 \\
\hline average $\Delta \mathbf{t}$ & $\mathbf{3 2 . 5 5}$ & $\mathbf{1 0 8 . 0 0}$ \\
\hline $\begin{array}{c}\text { cumulative } \Delta \mathbf{x} \\
(\mathbf{m})\end{array}$ & 17.08 & 57.50 \\
\hline average $\mathbf{~ ( m / s ) ~}$ & $\mathbf{0 . 5 2}$ & $\mathbf{0 . 5 3}$ \\
\hline
\end{tabular}


Table 24: Test 11 Velocity Measurements

\begin{tabular}{|c|c|c|c|}
\hline & $\begin{array}{c}\Delta t \\
(\mathrm{sec})\end{array}$ & $\Delta \mathbf{x}(\mathbf{m})$ & velocity $(\mathbf{m} / \mathbf{s})$ \\
\hline \multirow{4}{*}{$\begin{array}{l}\text { ping pong } \\
\text { ball tests }\end{array}$} & 28.66 & 22.50 & 0.79 \\
\hline & 28.56 & 22.50 & 0.79 \\
\hline & 28.75 & 22.50 & 0.78 \\
\hline & 28.37 & 22.50 & 0.79 \\
\hline average & 28.59 & 22.50 & 0.79 \\
\hline \multirow{4}{*}{$\begin{array}{l}\text { dye trace } \\
\text { tests }\end{array}$} & 27.75 & 22.50 & 0.81 \\
\hline & 28.52 & 22.50 & 0.79 \\
\hline & 30.44 & 22.50 & 0.74 \\
\hline & 31.50 & 22.50 & 0.71 \\
\hline average & 29.55 & 22.50 & 0.76 \\
\hline
\end{tabular}

Table 25: Test 11 Flow Rate Calculations

\begin{tabular}{|r|r|r|r|r|r|r|}
\hline & $\begin{array}{c}\text { flow depth } \\
(\mathbf{c m})\end{array}$ & $\begin{array}{c}\text { channel } \\
\text { width }(\mathbf{c m})\end{array}$ & $\begin{array}{c}\text { max channel } \\
\text { height }(\mathbf{c m})\end{array}$ & $\begin{array}{c}\text { Flow Area } \\
\left(\mathbf{c m}^{\mathbf{2}}\right)\end{array}$ & $\begin{array}{c}\text { Max Channel } \\
\text { Area }\left(\mathbf{c m}^{\mathbf{2}}\right)\end{array}$ & $\begin{array}{c}\text { Qmeasured } \\
(\mathbf{g p m})\end{array}$ \\
\hline & 1.25 & 20.50 & 10.00 & 25.63 & 205.00 & 31.55 \\
\hline & 1.25 & 23.00 & 12.00 & 28.75 & 276.00 & 35.35 \\
\hline & 2.13 & 22.00 & 12.00 & 46.75 & 264.00 & 57.38 \\
\hline & 1.50 & 25.00 & 13.00 & 37.50 & 325.00 & 46.13 \\
\hline & 1.13 & 24.00 & 13.00 & 27.00 & 312.00 & 33.13 \\
\hline Average & $\mathbf{1 . 4 5}$ & $\mathbf{2 2 . 9 0}$ & $\mathbf{1 2 . 0 0}$ & $\mathbf{3 4 . 6 6}$ & $\mathbf{2 6 7 . 5 0}$ & $\mathbf{4 2 . 6 4}$ \\
\hline
\end{tabular}

Table 26: Test 12 Velocity Measurements

\begin{tabular}{|c|c|r|r|}
\hline & $\begin{array}{c}\Delta \mathbf{t} \\
(\mathbf{s e c})\end{array}$ & $\Delta \mathbf{x}(\mathbf{m})$ & \multicolumn{1}{|c|}{$\begin{array}{c}\text { velocity } \\
(\mathbf{m} / \mathbf{s})\end{array}$} \\
\hline \multirow{4}{*}{$\begin{array}{c}\text { ping pong } \\
\text { ball tests }\end{array}$} & 44.74 & 35.00 & 0.78 \\
\cline { 2 - 4 } & 43.99 & 35.00 & 0.80 \\
\cline { 2 - 4 } & 44.64 & 35.00 & 0.78 \\
\cline { 2 - 4 } & 43.56 & 35.00 & 0.80 \\
\hline average & $\mathbf{4 4 . 2 3}$ & $\mathbf{3 5 . 0 0}$ & $\mathbf{0 . 7 9}$ \\
\hline \multirow{3}{*}{$\begin{array}{c}\text { dye trace } \\
\text { tests }\end{array}$} & 47.49 & 35.00 & 0.74 \\
\cline { 2 - 4 } & 48.17 & 35.00 & 0.73 \\
\cline { 2 - 4 } & 48.83 & 35.00 & 0.72 \\
\cline { 2 - 4 } & 49.02 & 35.00 & 0.71 \\
\hline average & $\mathbf{4 8 . 3 8}$ & $\mathbf{3 5 . 0 0}$ & $\mathbf{0 . 7 2}$ \\
\hline
\end{tabular}


Table 27: Test 12 Flow Rate Calculations

\begin{tabular}{|l|r|r|r|r|r|r|}
\hline & $\begin{array}{c}\text { flow depth } \\
(\mathbf{c m})\end{array}$ & $\begin{array}{c}\text { channel } \\
\text { width }(\mathbf{c m})\end{array}$ & $\begin{array}{c}\text { max channel } \\
\text { height }(\mathbf{c m})\end{array}$ & $\begin{array}{c}\text { Flow Area } \\
\left(\mathbf{c m}^{\mathbf{2}}\right)\end{array}$ & $\begin{array}{c}\text { Max Channel } \\
\text { Area }\left(\mathbf{c m}^{\mathbf{2}}\right)\end{array}$ & $\begin{array}{c}\text { Qmeasured } \\
(\mathbf{g p m})\end{array}$ \\
\hline & 3.25 & 23.00 & 12.00 & 74.75 & 276.00 & 89.72 \\
\hline & 2.75 & 24.00 & 10.00 & 66.00 & 240.00 & 79.26 \\
\hline & 1.00 & 20.00 & 13.00 & 20.00 & 260.00 & 23.94 \\
\hline & 1.75 & 22.50 & 12.00 & 39.38 & 270.00 & 47.24 \\
\hline average & 1.75 & 26.50 & 13.00 & 46.38 & 344.50 & 55.64 \\
\hline
\end{tabular}

Table 28: Test 15 Flow Rate Calculations

\begin{tabular}{|r|r|r|r|}
\hline & volume (L) & \multicolumn{1}{|c|}{$\Delta \mathbf{t}(\mathbf{s})$} & $\mathbf{Q} \mathbf{( g p m )}$ \\
\hline & 18.00 & 12.78 & 22.35 \\
\hline & 18.00 & 12.04 & 23.78 \\
\hline & 18.00 & 12.18 & 23.46 \\
\hline & 18.00 & 12.58 & 22.67 \\
\hline average & $\mathbf{1 8 . 0 0}$ & $\mathbf{1 2 . 4 0}$ & $\mathbf{2 2 . 9 9}$ \\
\hline
\end{tabular}

Table 29: Test 16 Flow Rate Calculation

\begin{tabular}{|r|r|r|r|}
\hline & volume $(\mathbf{L})$ & \multicolumn{1}{c|}{$\Delta \mathbf{t}(\mathbf{s})$} & $\mathbf{Q}(\mathbf{g p m})$ \\
\hline & 18.00 & 11.80 & 24.25 \\
\hline & 18.00 & 11.97 & 23.78 \\
\hline & 18.00 & 12.20 & 23.46 \\
\hline & 18.00 & 11.93 & 23.94 \\
\hline average & $\mathbf{1 8 . 0 0}$ & $\mathbf{1 1 . 9 8}$ & $\mathbf{2 3 . 7 8}$ \\
\hline
\end{tabular}

Table 30: Test 13 Flow Rate Calculation (bucket test)

\begin{tabular}{|l|r|r|r|r|r|}
\hline & volume (L) & $\Delta \mathbf{t}_{\mathbf{A}}(\mathbf{s})$ & $\Delta \mathbf{t}_{\mathbf{B}}(\mathbf{s})$ & $\begin{array}{c}\mathbf{Q}_{\mathbf{A}} \\
(\mathbf{g p m})\end{array}$ & $\begin{array}{c}\mathbf{Q}_{\mathbf{B}} \\
(\mathbf{g p m})\end{array}$ \\
\hline & 18.00 & 12.03 & 13.34 & 23.78 & 21.4 \\
\hline & 18.00 & 12.19 & 13.28 & 23.46 & 21.56 \\
\hline & 18.00 & 11.84 & 12.94 & 24.10 & 22.03 \\
\hline average & $\mathbf{1 8 . 0 0}$ & $\mathbf{1 2 . 0 2}$ & $\mathbf{1 3 . 1 9}$ & $\mathbf{2 3 . 7 8}$ & $\mathbf{2 1 . 7 2}$ \\
\hline
\end{tabular}


Table 31: Test 13Flow Rate Calculation (Woodburn Equation)

\begin{tabular}{|c|c|c|c|r|r|r|}
\hline & $\begin{array}{c}\Delta \mathbf{x} \\
(\mathbf{c m})\end{array}$ & $\begin{array}{c}\Delta \mathbf{h} \\
(\mathbf{c m})\end{array}$ & $\begin{array}{c}\text { Depth } \\
(\mathbf{c m})\end{array}$ & $\begin{array}{c}\text { Width } \\
(\mathbf{c m})\end{array}$ & $\mathbf{v}(\mathbf{m} / \mathbf{s})$ & $\mathbf{Q}(\mathbf{g p m})$ \\
\hline $\mathbf{6 A}$ & 42.00 & 106.00 & 2.50 & 9.50 & 0.91 & $\mathbf{3 4 . 0 8}$ \\
\hline $\mathbf{6 B}$ & 41.00 & 116.00 & 2.00 & 9.50 & 0.85 & $\mathbf{2 5 . 5 2}$ \\
\hline
\end{tabular}

Table 32: Test14 Flow Rate Calculation (bucket test)

\begin{tabular}{|r|r|r|r|r|r|}
\hline & volume $(\mathbf{L})$ & $\Delta \mathbf{t}_{\mathbf{A}}(\mathbf{s})$ & $\Delta \mathbf{t}_{\mathbf{B}}(\mathbf{s})$ & $\begin{array}{c}\mathbf{Q}_{\mathbf{A}} \\
(\mathbf{g p m})\end{array}$ & $\begin{array}{c}\mathbf{Q}_{\mathbf{B}} \\
(\mathbf{g p m})\end{array}$ \\
\hline & 18.00 & 12.50 & 18.07 & 22.83 & 15.85 \\
\hline & 18.00 & 12.50 & 18.20 & 22.83 & 15.69 \\
\hline & 18.00 & 12.24 & 18.06 & 23.30 & 15.85 \\
\hline & 18.00 & 12.47 & 18.25 & 22.83 & 15.69 \\
\hline average & $\mathbf{1 8 . 0 0}$ & $\mathbf{1 2 . 4 3}$ & $\mathbf{1 8 . 1 5}$ & $\mathbf{2 2 . 9 9}$ & $\mathbf{1 5 . 7 2}$ \\
\hline
\end{tabular}

Table 33: Test 14 Flow Rate Calculation (Woodburn Equation)

\begin{tabular}{|c|c|c|r|r|r|r|}
\hline & $\begin{array}{c}\Delta \mathbf{x} \\
(\mathbf{c m})\end{array}$ & $\begin{array}{c}\Delta \mathbf{h} \\
(\mathbf{c m})\end{array}$ & $\begin{array}{c}\text { depth } \\
(\mathbf{c m})\end{array}$ & \multicolumn{1}{c|}{$\begin{array}{c}\text { width } \\
(\mathbf{c m})\end{array}$} & $\mathbf{v}(\mathbf{m} / \mathbf{s})$ & $\mathbf{Q}(\mathbf{g p m})$ \\
\hline 7A & 35.00 & 105.00 & 2.00 & 10.00 & 0.76 & $\mathbf{2 4 . 1 0}$ \\
\hline 7B & 30.00 & 97.00 & 2.00 & 9.00 & 0.68 & $\mathbf{1 9 . 3 4}$ \\
\hline
\end{tabular}

Table 34: Tests 17-18 Flow Rate Calculation (bucket test)

\begin{tabular}{|c|c|c|c|c|c|}
\cline { 3 - 6 } \multicolumn{2}{c|}{} & \multicolumn{2}{c|}{$\begin{array}{c}\text { Upper } \\
\text { Fountain }\end{array}$} & \multicolumn{2}{c|}{$\begin{array}{c}\text { Princess } \\
\text { Fountain }\end{array}$} \\
\hline & $\begin{array}{c}\text { volume } \\
(\mathbf{L})\end{array}$ & $\Delta \mathbf{t}(\mathbf{s})$ & $\begin{array}{c}\mathbf{Q} \\
(\mathbf{g p m})\end{array}$ & $\Delta \mathbf{t} \mathbf{( s )}$ & $\begin{array}{c}\mathbf{Q} \\
(\mathbf{g p m})\end{array}$ \\
\hline & 18.00 & 37.60 & 7.61 & 19.77 & 14.43 \\
\hline & 18.00 & 38.87 & 7.29 & 19.10 & 14.90 \\
\hline & 18.00 & 38.40 & 7.45 & 19.20 & 14.90 \\
\hline average & $\mathbf{1 8 . 0 0}$ & $\mathbf{3 8 . 2 9}$ & $\mathbf{7 . 4 5}$ & $\mathbf{1 9 . 3 6}$ & $\mathbf{1 4 . 7 4}$ \\
\hline
\end{tabular}


Table 35: Tests 17-18 Flow Rate Calculation (Woodburn Equation)

\begin{tabular}{|c|c|c|r|r|r|r|}
\hline & $\begin{array}{c}\Delta \mathbf{x} \\
(\mathbf{c m})\end{array}$ & $\begin{array}{c}\Delta \mathbf{h} \\
(\mathbf{c m})\end{array}$ & \multicolumn{1}{c|}{$\begin{array}{c}\text { depth } \\
(\mathbf{c m})\end{array}$} & \multicolumn{1}{c|}{$\begin{array}{c}\text { width } \\
(\mathbf{c m})\end{array}$} & $\mathbf{v}(\mathbf{m} / \mathbf{s})$ & $\mathbf{Q}(\mathbf{L} / \mathbf{s})$ \\
\hline $\begin{array}{c}\text { Upper } \\
\text { Fountain }\end{array}$ & 45.00 & 125.00 & 1.00 & 8.00 & 0.89 & $\mathbf{1 1 . 2 6}$ \\
\hline $\begin{array}{c}\text { Princess } \\
\text { Fountain }\end{array}$ & 33.00 & 133.00 & 2.00 & 8.50 & 0.64 & $\mathbf{1 7 . 1 2}$ \\
\hline
\end{tabular}

Table 36: Valve options for channels C8, C9, C10, and C12

\begin{tabular}{|l|l|l|l|}
\hline C8 & C9 & C10 & C12 \\
\hline On & On & On & On \\
\hline On & On & On & Off \\
\hline On & On & Off & On \\
\hline On & Off & On & On \\
\hline Off & On & On & On \\
\hline On & On & Off & Off \\
\hline On & Off & On & Off \\
\hline On & Off & Off & On \\
\hline Off & Off & On & On \\
\hline Off & On & On & Off \\
\hline Off & On & Off & On \\
\hline Off & Off & Off & On \\
\hline Off & Off & On & Off \\
\hline Off & On & Off & Off \\
\hline On & Off & Off & Off \\
\hline Off & Off & Off & Off \\
\hline
\end{tabular}

Table 37: \% difference in flow estimation for dye and ping-pong ball methods

\begin{tabular}{|l|l|l|l|}
\hline Fountain & $\mathbf{Q}_{\text {dye }}(\mathbf{g p m})$ & $\mathbf{Q}_{\text {ball }}(\mathbf{g p m})$ & $\boldsymbol{\%}$ difference \\
\hline $\mathbf{1}$ & 10.8 & 8.99 & $17.1 \%$ \\
\hline $\mathbf{2}$ & 10.8 & 8.99 & $17.1 \%$ \\
\hline $\mathbf{3}$ & 10.8 & 8.99 & $17.1 \%$ \\
\hline $\mathbf{4 A}$ & 45.3 & 45.3 & $0.00 \%$ \\
\hline
\end{tabular}


Table 38: \% difference in flow estimation for Woodburn and Bucket methods

\begin{tabular}{|l|l|l|l|}
\hline Fountain & $\mathbf{Q}_{\mathbf{W}}(\mathbf{g p m})$ & $\mathbf{Q}_{\mathbf{B}}(\mathbf{g p m})$ & $\mathbf{\%}$ difference \\
\hline $\mathbf{4 A}$ & 28.3 & 26.9 & $4.96 \%$ \\
\hline $\mathbf{6 A}$ & 33.9 & 23.7 & $30.0 \%$ \\
\hline $\mathbf{6 B}$ & 25.3 & 21.6 & $14.6 \%$ \\
\hline $\mathbf{7 A}$ & 23.9 & 23.0 & $4.06 \%$ \\
\hline 7B & 19.2 & 15.7 & $18.1 \%$ \\
\hline King's Bath & 33.7 & 26.8 & $20.3 \%$ \\
\hline RA & 3.88 & 4.04 & $3.98 \%$ \\
\hline RB & 17.2 & 24.8 & $44.3 \%$ \\
\hline RC & 2.66 & 2.80 & $5.06 \%$ \\
\hline Upper Fountain & 11.3 & 7.45 & $34.1 \%$ \\
\hline Princess Fountain & 17.1 & 14.7 & $13.6 \%$ \\
\hline
\end{tabular}

Table 39: Capacities of source canals in the Patacancha watershed

\begin{tabular}{|l|l|l|l|l|}
\hline & $\mathbf{1 0 0 \%}$ full & $\mathbf{8 0 \%}$ full & $\mathbf{5 0 \%}$ full & $\mathbf{3 0 \%}$ full \\
\hline Canals & $\mathbf{Q}(\mathbf{g a l} / \mathbf{m i n})$ & $\mathbf{Q}(\mathbf{g a l} / \mathbf{m i n})$ & $\mathbf{Q}(\mathbf{g a l} / \mathbf{m i n})$ & $\mathbf{Q}$ (gal/min) \\
\hline San Pablo & 3146 & 2342 & 1225 & 583 \\
\hline Musk'a Pujhio & 583 & 439 & 235 & 114 \\
\hline PaqchapataChute & 26330 & 18513 & 8721 & 4345 \\
\hline Lower Paqchapata & 1520 & 1129 & 587 & 278 \\
\hline Media Luna & 1066 & 799 & 424 & 204 \\
\hline Pre-Inca & 1480 & 1104 & 579 & 276 \\
\hline Inca Twin & 1480 & 1104 & 579 & 276 \\
\hline Inca Diversion & 821 & 581 & 277 & 122 \\
\hline Bandolista Canal & 1182 & 898 & 490 & 243 \\
\hline Bandolista Chute & 486 & 343 & 163 & 72 \\
\hline Huaca Canal & 5231 & 3893 & 2034 & 966 \\
\hline Manyaraqui Canal & 21757 & 15427 & 7369 & 3170 \\
\hline
\end{tabular}


Table 40: Values for hydraulic radius at $80 \%$ and $50 \%$ flow depth

\begin{tabular}{|l|c|c|}
\hline Channel & $\begin{array}{c}\mathbf{R}_{\mathbf{H}}(\mathbf{c m}) \\
\mathbf{( 8 0 \% )}\end{array}$ & $\begin{array}{c}\mathbf{R}_{\mathbf{H}}(\mathbf{c m}) \\
\mathbf{( 5 0 \%})\end{array}$ \\
\hline H1 & 15.2 & 11.5 \\
\hline H2 & 4.62 & 3.40 \\
\hline H3 & 4.80 & 3.53 \\
\hline C1 & 3.98 & 3.25 \\
\hline C3 & 2.23 & 1.84 \\
\hline C4 & 2.67 & 2.19 \\
\hline C5 & 4.01 & 2.28 \\
\hline C6 & 3.27 & 3.23 \\
\hline C7 & 4.83 & 2.57 \\
\hline C8 & 5.01 & 4.84 \\
\hline C9 & 4.65 & 3.60 \\
\hline C10 & 5.68 & 4.28 \\
\hline C11 & 6.21 & 5.23 \\
\hline C12 & 4.71 & 3.94 \\
\hline C13 & 6.48 & 5.35 \\
\hline C14 & 5.28 & 4.24 \\
\hline C15 & 3.08 & 2.50 \\
\hline C16 & 1.87 & 1.38 \\
\hline C17 & 2.36 & 1.64 \\
\hline C18 & 1.09 & 0.86 \\
\hline C19 & 2.46 & 2.00 \\
\hline C20 & 2.62 & 2.13 \\
\hline
\end{tabular}


Table 41: Channel flow characterization for $80 \%$ and $50 \%$ flow depths

\begin{tabular}{|l|l|l|l|l|l|l|l|l|}
\hline Channel & $\mathbf{. 8 ~ d}(\mathbf{c m})$ & $\mathbf{v}(\mathbf{m} / \mathbf{s})$ & $\mathbf{F r}(\mathbf{8 0})$ & $\mathbf{R e}(\mathbf{8 0 \%})$ & $\mathbf{. 5 ~ d}(\mathbf{c m})$ & $\mathbf{v}(\mathbf{m} / \mathbf{s})$ & $\mathbf{F r}(\mathbf{5 0 \%})$ & $\mathbf{R e}(\mathbf{5 0 \%})$ \\
\hline H1 & 28.54 & 0.180 & 0.108 & 109888 & 17.84 & 0.150 & 0.113 & 69161 \\
\hline H2 & 7.74 & 0.429 & 0.493 & 79452 & 4.84 & 0.350 & 0.508 & 47668 \\
\hline H3 & 8.00 & 0.650 & 0.734 & 124806 & 5.00 & 0.530 & 0.756 & 74760 \\
\hline C1 & 10.64 & 0.388 & 0.380 & 61774 & 6.65 & 0.339 & 0.420 & 44092 \\
\hline C2 & 6.40 & 0.264 & 0.333 & 23500 & 4.00 & 0.233 & 0.371 & 17133 \\
\hline C3 & 7.20 & 0.421 & 0.501 & 45045 & 4.50 & 0.369 & 0.555 & 32219 \\
\hline C4 & 5.60 & 0.456 & 0.615 & 54867 & 3.50 & 0.378 & 0.646 & 34442 \\
\hline C5 & 9.60 & 0.786 & 0.810 & 127273 & 6.00 & 0.676 & 0.881 & 87393 \\
\hline C6 & 7.20 & 0.482 & 0.574 & 63140 & 4.50 & 0.411 & 0.618 & 42242 \\
\hline C7 & 11.20 & 0.625 & 0.597 & 120894 & 7.00 & 0.536 & 0.647 & 82369 \\
\hline C8 & 17.60 & 0.640 & 0.487 & 128306 & 11.00 & 0.577 & 0.555 & 98662 \\
\hline C9 & 9.60 & 0.609 & 0.628 & 113185 & 6.00 & 0.514 & 0.670 & 74010 \\
\hline C10 & 10.40 & 0.696 & 0.689 & 158113 & 6.50 & 0.576 & 0.722 & 98606 \\
\hline C11 & 20.00 & 0.739 & 0.528 & 183475 & 12.50 & 0.659 & 0.596 & 138031 \\
\hline C12 & 14.40 & 0.615 & 0.517 & 115842 & 9.00 & 0.546 & 0.581 & 85932 \\
\hline C13 & 18.40 & 0.538 & 0.400 & 139349 & 11.50 & 0.473 & 0.446 & 101244 \\
\hline C14 & 12.80 & 0.469 & 0.419 & 99220 & 8.00 & 0.405 & 0.457 & 68614 \\
\hline C15 & 8.00 & 0.327 & 0.369 & 40284 & 5.00 & 0.285 & 0.407 & 28500 \\
\hline C16 & 3.20 & 0.235 & 0.419 & 17568 & 2.00 & 0.192 & 0.434 & 10645 \\
\hline C17 & 3.20 & 0.388 & 0.692 & 36630 & 2.00 & 0.304 & 0.686 & 19888 \\
\hline C18 & 2.40 & 0.434 & 0.894 & 18929 & 1.50 & 0.369 & 0.963 & 12664 \\
\hline C19 & 6.40 & 0.282 & 0.356 & 27773 & 4.00 & 0.246 & 0.392 & 19648 \\
\hline C20 & 6.80 & 0.294 & 0.360 & 30725 & 4.25 & 0.256 & 0.396 & 21737 \\
\hline
\end{tabular}




\section{Appendix II}

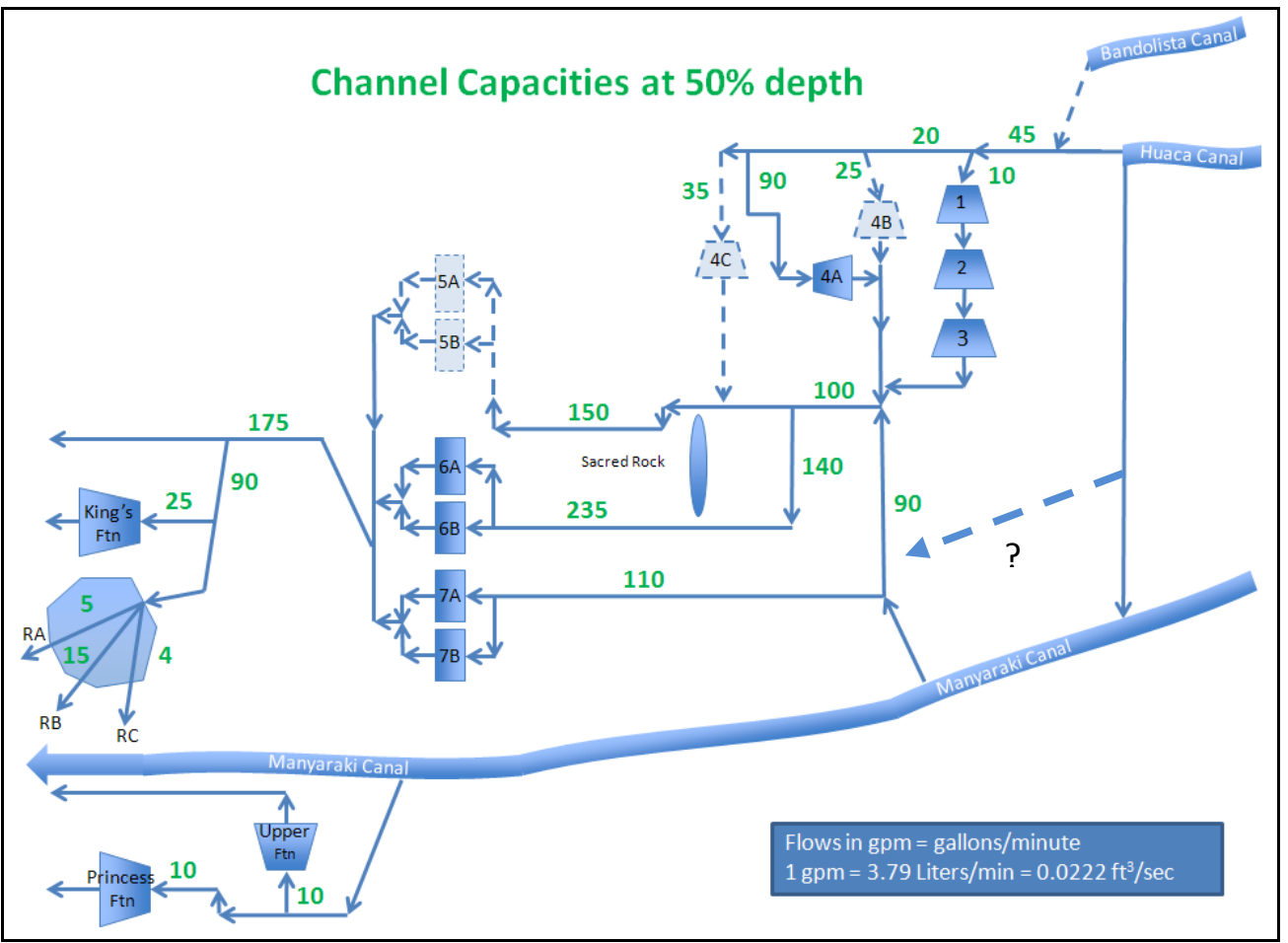

Figure 38: Channel capacities at 50\% channel depth

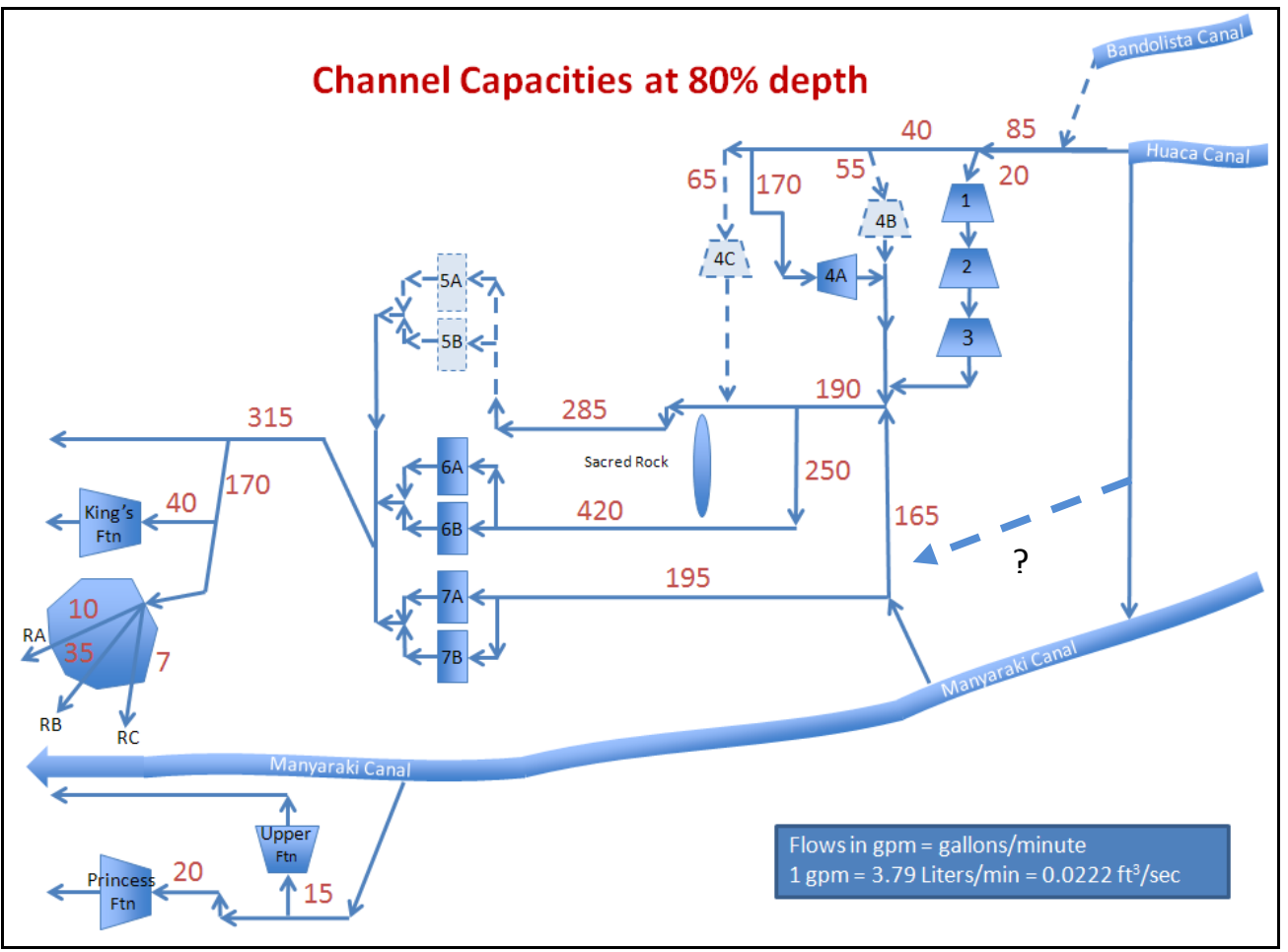

Figure 39: Channel capacities at 80\% channel depth 


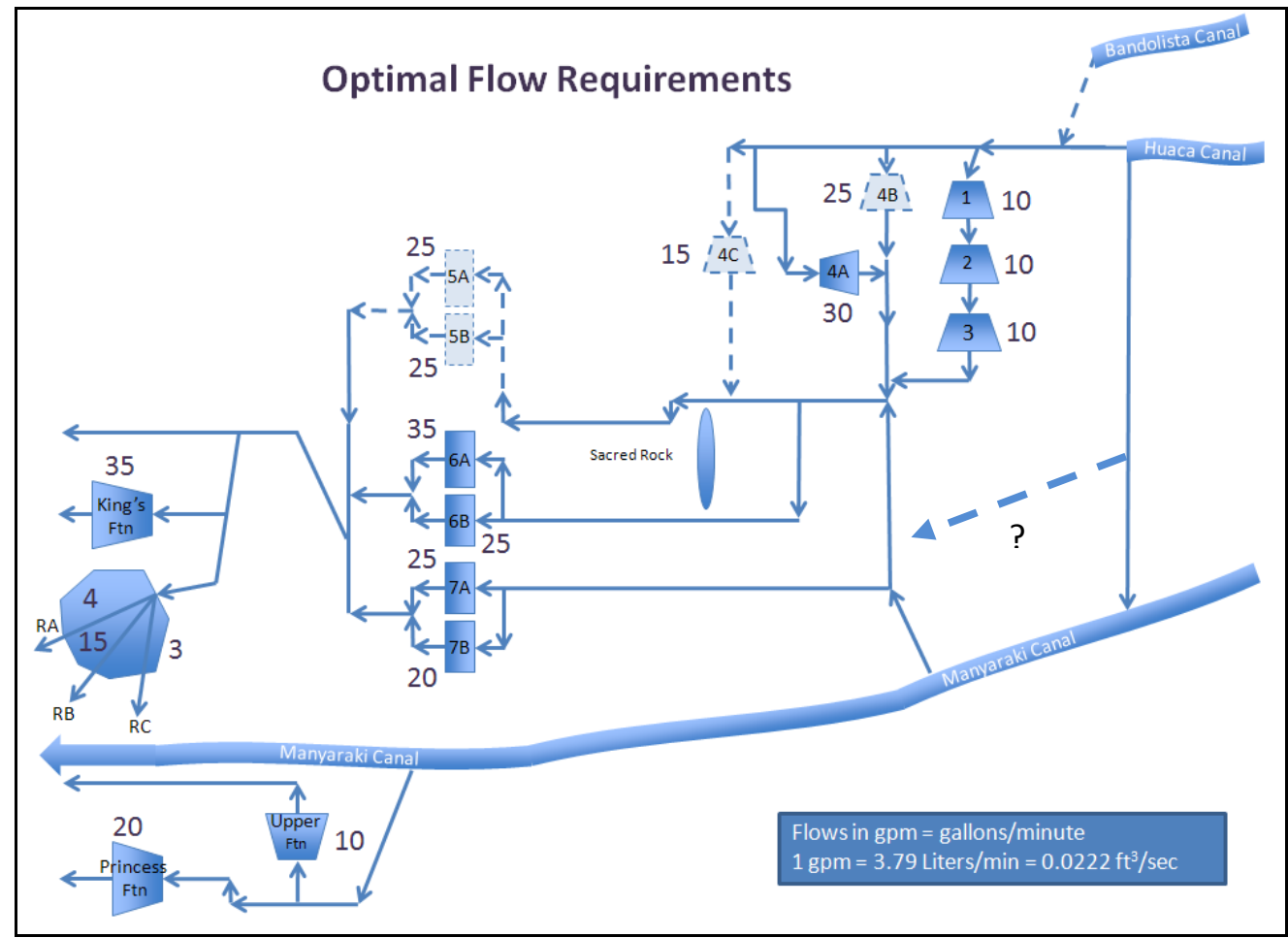

Figure 40: Optimal flow requirements to fountains

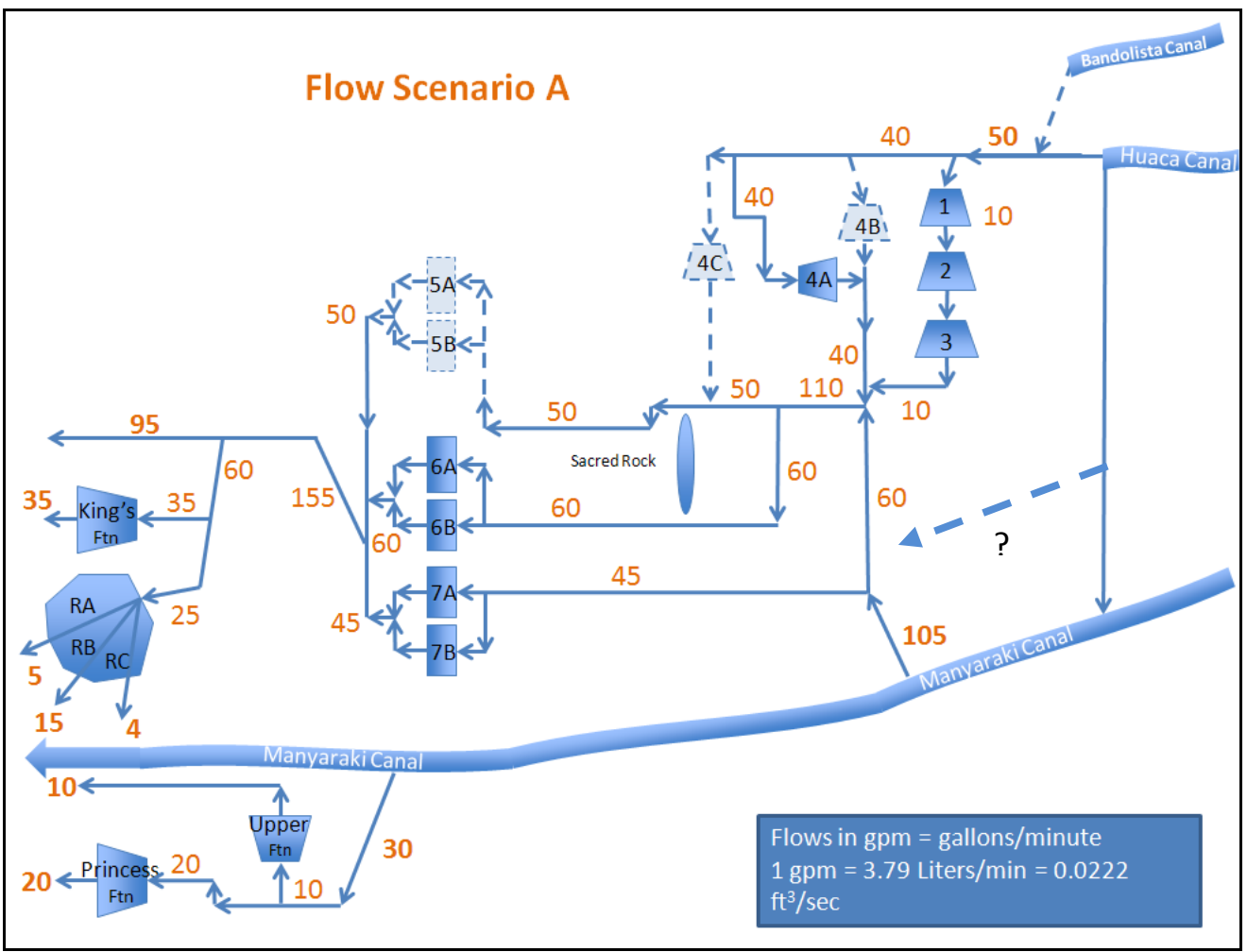

Figure 41: Optimal flow requirements: No flow to fountains 4B \& 4C 


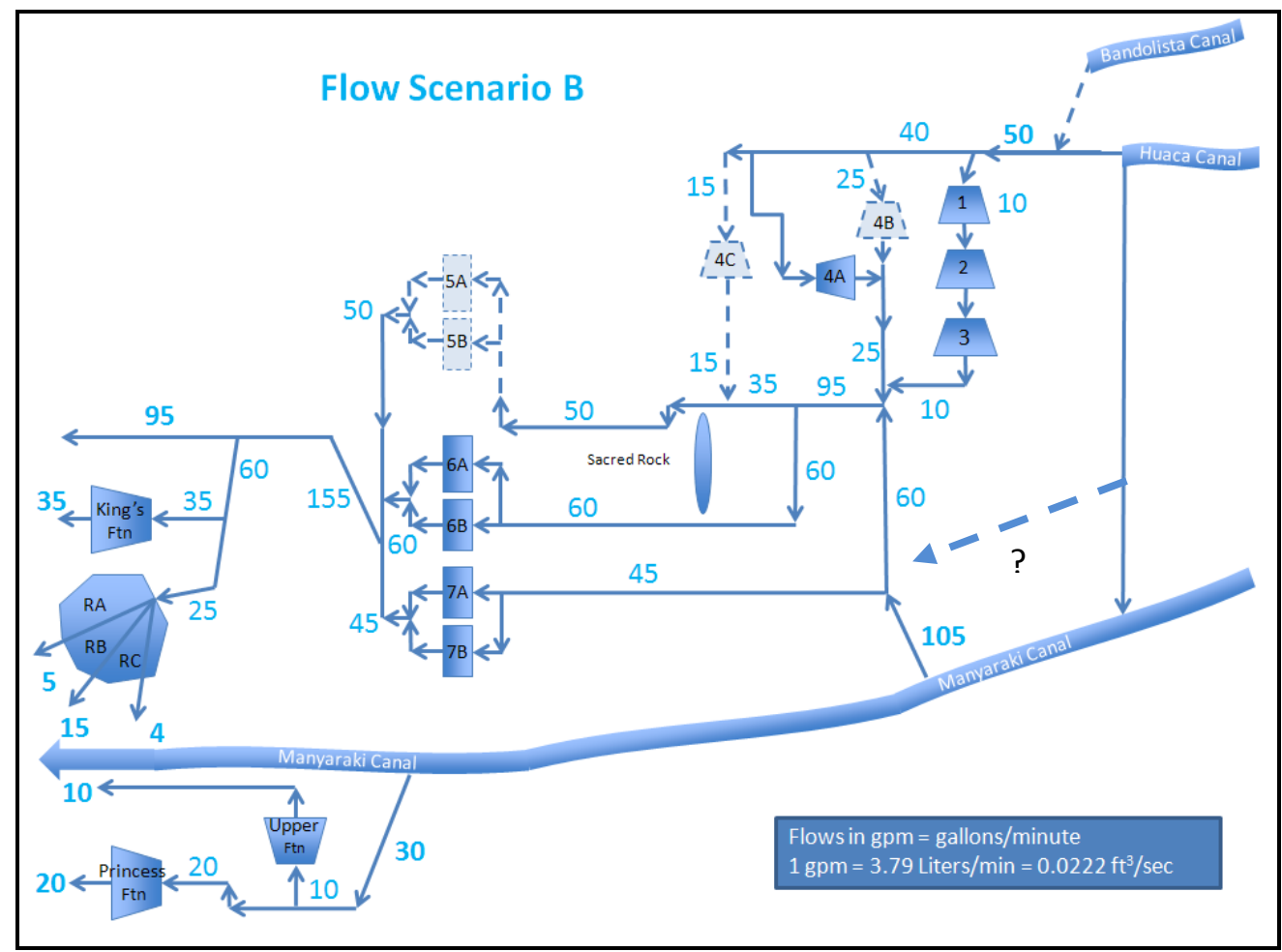

Figure 42: Optimal flow requirements: No flow to fountain 4A

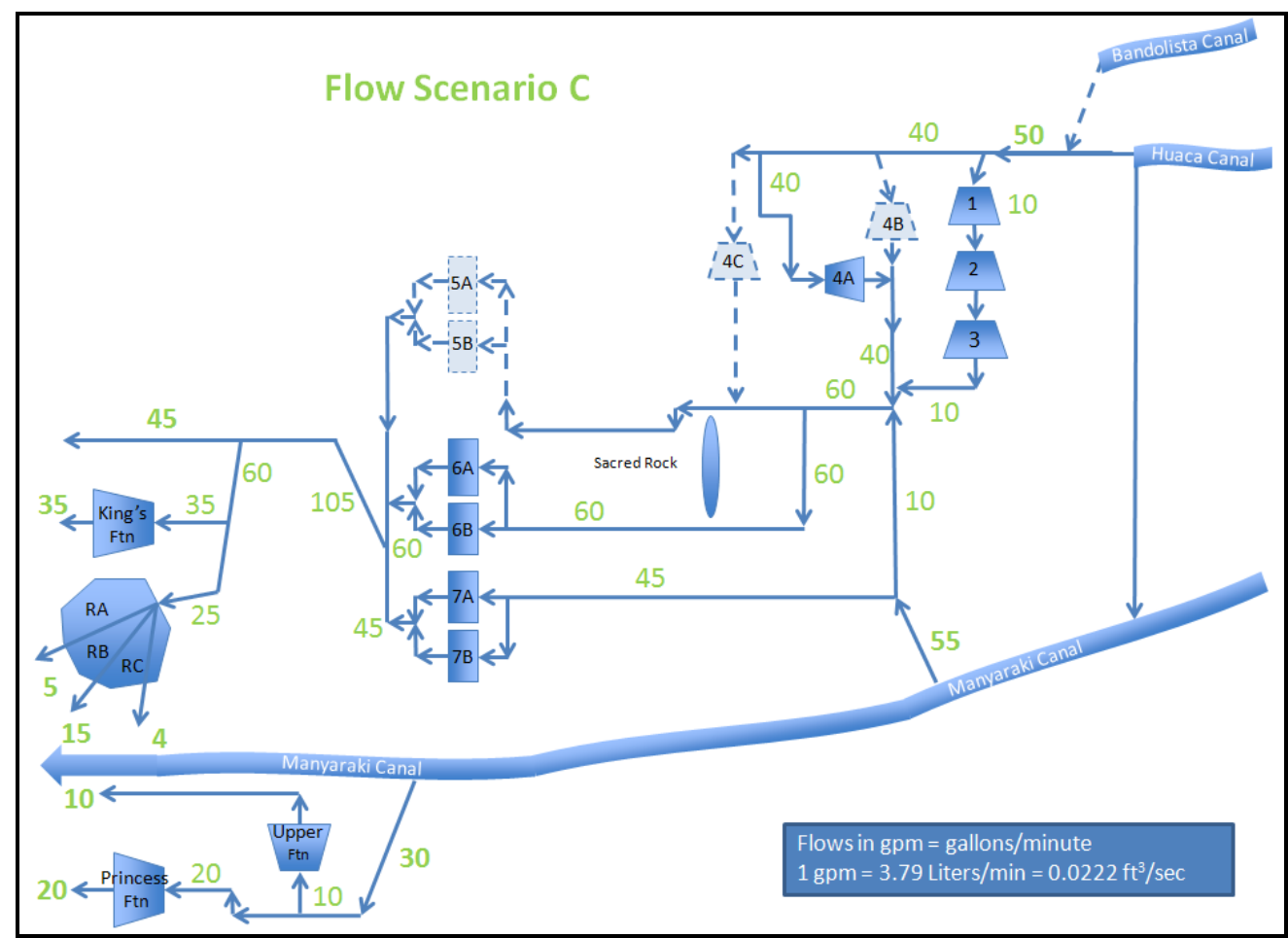

Figure 43: Optimal flow requirements: No flow to fountains 4B, 4C, 5A, and 5B 


\section{TECHNICAL DATA BULLETIN}

Bright Dyes Yellow/Green products are specially formulated versions of Xanthene dye, certified by NSF International to ANSI/NSF Standard 60 for use in drinking water. This dye is the traditional fluorescent water tracing and leak detection material and has been used for labeling studies from the beginning of the century. It may be detected visually, by UV light and by appropriate fluoremetric equipment. Today it is most often used visually. This dye has been used by the military to mark downed pilots for search and rescue operations over large water bodies. Visually the dye appears yellow/green, depending on its concentration and under UV light as lime green.

Based on biochemical oxygen demand (BOD) studies, the dye is biodegradable with $65 \%$ of the available oxygen consumed in 7 days. The dye is resistant to absorption on most suspended matter in fresh and salt water. However, compared to Bright Dyes FWT Red products it is significantly less resistant to degradation by sunlight and when used in fluoremetry, stands out much less clearly against background fluorescence. As always the suitability of these products for any specific application should be evaluated by a qualified hydrologist or other industry professional.

\begin{tabular}{|c|c|c|c|}
\hline General Properties & Tablets & Liquids & Powders \\
\hline Detectability of active ingredient $^{1}$ & Visual $<100 \mathrm{ppb}$ & Visual $<100 \mathrm{ppb}$ & Visual $<100 \mathrm{ppb}$ \\
\hline Maximum absorbance wavelength ${ }^{2}$ & $490 / 520 \mathrm{~nm}$ & $490 / 520 \mathrm{~nm}$ & $490 / 520 \mathrm{~nm}$ \\
\hline Appearance & $\begin{array}{l}\text { Orange convex } \\
1.6 \mathrm{~cm} \text { diameter }\end{array}$ & $\begin{array}{l}\text { Reddish, brown } \\
\text { aqueous solution }\end{array}$ & $\begin{array}{l}\text { Orange fine } \\
\text { powder }\end{array}$ \\
\hline NSF (Max use level in potable water) & $6.0 \mathrm{ppb}$ & $10.0 \mathrm{ppb}$ & $1.0 \mathrm{ppb}$ \\
\hline Weight & $1.35 \mathrm{gms} \pm 0.05$ & & \\
\hline Dissolution Time ${ }^{3}$ & $\begin{array}{l}50 \%<3 \text { minutes } \\
95 \%<6 \text { minutes }\end{array}$ & & $\begin{array}{l}50 \%<3 \text { minutes } \\
95 \%<6 \text { minutes }\end{array}$ \\
\hline Specific Gravity & & $1.05 \pm 0.05 @ 25^{\circ} \mathrm{C}$ & \\
\hline Viscosity ${ }^{4}$ & & $1.8 \mathrm{cps}$ & \\
\hline $\mathrm{pH}$ & & $8.5+0.5 @ 25^{\circ} \mathrm{C}$ & \\
\hline
\end{tabular}

Figure 44: Technical Data for Yellow/Green Dye Products

\section{TECHNICAL DATA BULLETIN}

Bright Dyes FLT Blue products are specially formulated versions of food grade dye FD \& C Blue. Bright Dyes FLT Blue products have been certified by NSF International to the ANSI/NSF Standard 60 for use in drinking water. This dye is used for visual detection only and cannot be seen under ultraviolet light or detected by fluorometry. However, when used visually, its color is often thought to be more acceptable to public view than the fluorescing red or yellow green Bright Dyes products. In this respect, it is sometimes used in fountains, ponds and streams for decorative effect. Visually, the dye appears as aqua to royal blue depending on its concentration and activity of the water.

Based on biochemical oxygen demand (BOD) studies, the dye is biodegradable with $77 \%$ of the available oxygen consumed in 7 days. As always the suitability of these products for any specific application should be evaluated by a qualified hydrologist or other industry professional.

\begin{tabular}{|c|c|c|c|}
\hline General Properties & Tablets & Liquids & Powders \\
\hline Detectability of active ingredient ${ }^{1}$ & Visual $<100 \mathrm{ppb}$ & Visual $<100 \mathrm{ppb}$ & Visual $<100 \mathrm{ppb}$ \\
\hline Maximum absorbance wavelength ${ }^{2}$ & $630 \mathrm{~nm}$ & $630 \mathrm{~nm}$ & $630 \mathrm{~nm}$ \\
\hline Appearance & $\begin{array}{l}\text { Lt. Blue speckled } \\
1.6 \mathrm{~cm} \text { diameter }\end{array}$ & $\begin{array}{l}\text { Clear, dark blue } \\
\text { aqueous solution }\end{array}$ & $\begin{array}{l}\text { Deep violet fine } \\
\text { powder }\end{array}$ \\
\hline NSF, max use levels in potable water & $2000 \mathrm{ppb}$ & $1200 \mathrm{ppb}$ & $100 \mathrm{ppb}$ \\
\hline Weight & $1.25 \mathrm{gms}+0.05$ & & \\
\hline Dissolution Time $^{3}$ & $\begin{array}{l}50 \%<3 \text { minutes } \\
95 \%<6 \text { minutes }\end{array}$ & & $\begin{array}{l}50 \%<3 \text { minutes } \\
95 \%<6 \text { minutes }\end{array}$ \\
\hline Specific Gravity & & $1.04 \pm 0.03 @ 25^{\circ} \mathrm{C}$ & \\
\hline Viscosity $^{4}$ & & $1.8 \mathrm{cps}$ & \\
\hline $\mathrm{pH}$ & & $5.2 \pm 1.0 @ 25^{\circ} \mathrm{C}$ & \\
\hline
\end{tabular}

Figure 45: Technical Data for Blue Dye Products 


\section{TECHNICAL DATA BULLETIN}

Bright Dyes FLT Orange products are specially formulated versions of Xanthene dye for convenient use in water tracing and leak detection studies. This fluorescent orange dye is certified by NSF International to ANSI/NSF Standard 60 for use in drinking water. It may be detected visually, by ultraviolet light and by appropriate fluoremetric equipment. Today it is most often used visually. Visually the dye appears orange to red-orange, depending on its concentration and under ultraviolet light as bright yellow.

The dye is resistant to absorption on most suspended matter in fresh and salt water. However, compared to Bright Dyes FLT Yellow/Green products it is slightly more resistant to degradation by sunlight but less resistant than our FWT Red products. As always the suitability of these products for any specific application should be evaluated by a qualified hydrologist or other industry professional.

\begin{tabular}{|c|c|c|c|}
\hline General Properties & Tablets & Liquids & Powders \\
\hline Detectability of active ingredient ${ }^{1}$ & Visual $<100 \mathrm{ppb}$ & Visual $<100 \mathrm{ppb}$ & Visual $<100 \mathrm{ppb}$ \\
\hline Maximum absorbance wavelength ${ }^{2}$ & $515 / 535 \mathrm{~nm}$ & $515 / 535 \mathrm{~nm}$ & $515 / 535 \mathrm{~nm}$ \\
\hline Appearance & $\begin{array}{l}\text { Brick red convex } \\
1.6 \mathrm{~cm} \text { diameter }\end{array}$ & $\begin{array}{l}\text { Reddish-Orange } \\
\text { aqueous solution }\end{array}$ & $\begin{array}{l}\text { Brick red fine } \\
\text { powder }\end{array}$ \\
\hline NSF (Max use level in potable water) & $0.3 \mathrm{ppb}$ & $0.8 \mathrm{ppb}$ & $0.1 \mathrm{ppb}$ \\
\hline Weight & 1.35 gms \pm 0.05 & & \\
\hline Dissolution Time ${ }^{3}$ & $\begin{array}{l}50 \%<3 \text { minutes } \\
95 \%<6 \text { minutes }\end{array}$ & & $\begin{array}{l}50 \%<3 \text { minutes } \\
95 \%<6 \text { minutes }\end{array}$ \\
\hline Specific Gravity & & $1.05 \pm 0.05 @ 25^{\circ} \mathrm{C}$ & \\
\hline Viscosity $^{4}$ & & $1.8 \mathrm{cps}$ & \\
\hline $\mathrm{pH}$ & $7.5 \pm 0.5$ & $8.0 \pm 0.5 @ 25^{\circ} \mathrm{C}$ & $7.5 \pm 0.5$ \\
\hline
\end{tabular}

Figure 46: Technical Data for Orange Dye Products

\section{Supplementary Sources}

Additional sources for further understanding of the research done at Ollantaytambo include:

1. Data compiled in the field books of engineers:

- Benjamin Doran

- Dr. Richard Miksad

- Kenneth Wright

- Ken Lohr

- Luke Wildfire

2. CAD files of the site done by Wright Paleohydrologial Institute

3. Excel file of the simulation model

4. Powerpoint file of the final thesis presentation 